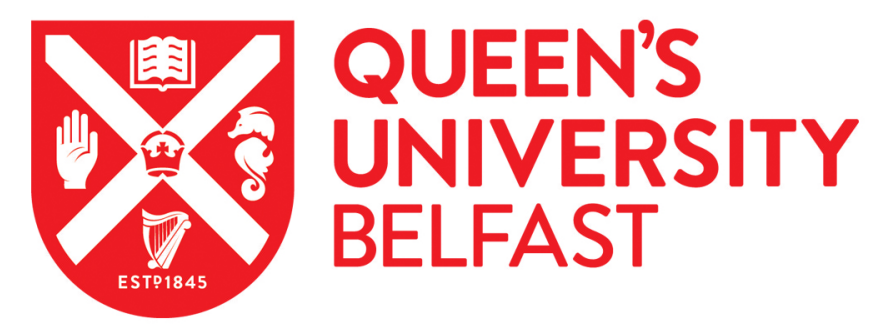

\title{
Psychosocial interventions to improve quality of life and emotional wellbeing for recently diagnosed cancer patients
}

Galway, K., Black, A., Cantwell, M., Cardwell, C., Mills, M., \& Donnelly, M. (2012). Psychosocial interventions to improve quality of life and emotional wellbeing for recently diagnosed cancer patients. Cochrane database of systematic reviews (Online), 2012(11), [CD007064]. https://doi.org/10.1002/14651858.CD007064.pub2

Published in:

Cochrane database of systematic reviews (Online)

Document Version:

Publisher's PDF, also known as Version of record

Queen's University Belfast - Research Portal:

Link to publication record in Queen's University Belfast Research Portal

Publisher rights

(c) 2015 The Cochrane Collaboration

\section{General rights}

Copyright for the publications made accessible via the Queen's University Belfast Research Portal is retained by the author(s) and / or other copyright owners and it is a condition of accessing these publications that users recognise and abide by the legal requirements associated with these rights.

Take down policy

The Research Portal is Queen's institutional repository that provides access to Queen's research output. Every effort has been made to ensure that content in the Research Portal does not infringe any person's rights, or applicable UK laws. If you discover content in the Research Portal that you believe breaches copyright or violates any law, please contact openaccess@qub.ac.uk. 


\section{Psychosocial interventions to improve quality of life and emotional wellbeing for recently diagnosed cancer patients (Review)}

Galway K, Black A, Cantwell M, Cardwell CR, Mills M, Donnelly M

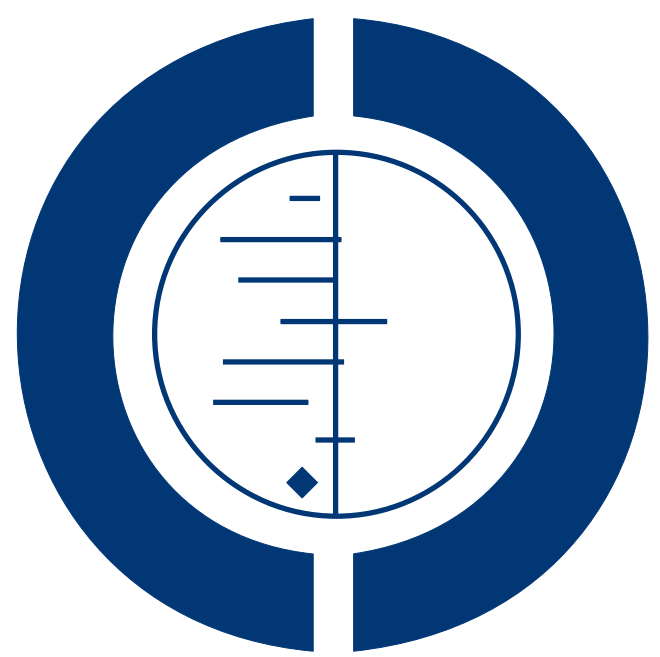

\section{THE COCHRANE COLLABORATION $^{\circledR}$}

This is a reprint of a Cochrane review, prepared and maintained by The Cochrane Collaboration and published in The Cochrane Library 2012, Issue 11

http://www.thecochranelibrary.com

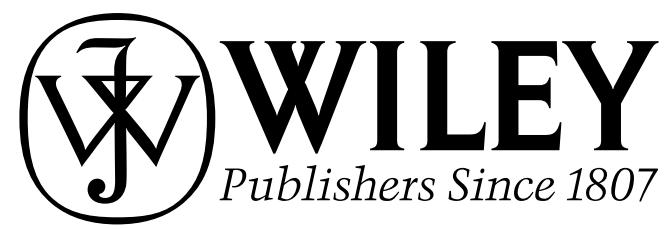

Psychosocial interventions to improve quality of life and emotional wellbeing for recently diagnosed cancer patients (Review) Copyright $\odot 2012$ The Cochrane Collaboration. Published by John Wiley \& Sons, Ltd. 
TABLE OF CONTENTS

HEADER . . . . . . . . . . . . . . . . . . . . . . . . . . . . . . . . . . 1

ABSTRACT . . . . . . . . . . . . . . . . . . . . . . . . . . . . . . . . . . . . . . .

PLAIN LANGUAGE SUMMARY . . . . . . . . . . . . . . . . . . . . . . . . . . . . . . . . . . . . . . . . . . . . .

SUMMARY OF FINDINGS FOR THE MAIN COMPARISON $\quad$. . . . . . . . . . . . . . . . . . . . . . . . . .

BACKGROUND . . . . . . . . . . . . . . . . . . . . . . . . . . . . . . . . . . . . . . 3

OBJECTIVES . . . . . . . . . . . . . . . . . . . . . . . . . . . . . . . . . . . . . . . . . . . . . . . . . .

METHODS . . . . . . . . . . . . . . . . . . . . . . . . . . . . . . . . . . . . . . 4

RESULTS . . . . . . . . . . . . . . . . . . . . . . . . . . . . . . . . . . . . . . . 7

Figure 1. . . . . . . . . . . . . . . . . . . . . . . . . . . . . . . . . . . . . . 8

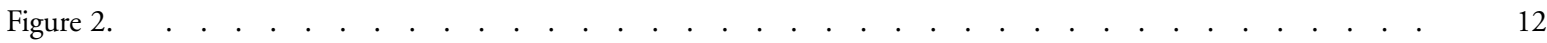

Figure 3. . . . . . . . . . . . . . . . . . . . . . . . . . . . . . . . . . . . . . 12

Figure $4 . \quad$. . . . . . . . . . . . . . . . . . . . . . . . . . . . . . . . . . . . . 13

Figure 5. . . . . . . . . . . . . . . . . . . . . . . . . . . . . . . . . . . . . . 14

Figure 6. . . . . . . . . . . . . . . . . . . . . . . . . . . . . . . . . . . . . . 15

Figure 7. . . . . . . . . . . . . . . . . . . . . . . . . . . . . . . . . 16

DISCUSSION . . . . . . . . . . . . . . . . . . . . . . . . . . . . . . . . . . . . . . . . . . . .

AUTHORS' CONCLUSIONS . . . . . . . . . . . . . . . . . . . . . . . . . . . . . . . . 18

ACKNOWLEDGEMENTS . . . . . . . . . . . . . . . . . . . . . . . . . . . . . . . . . . . . . .

REFERENCES . . . . . . . . . . . . . . . . . . . . . . . . . . . . . . . . . . . . . . . . . . . . . . 19

CHARACTERISTICS OF STUDIES . . . . . . . . . . . . . . . . . . . . . . . . . . . . . . . . . . . . . . .

DATA AND ANALYSES . . . . . . . . . . . . . . . . . . . . . . . . . . . . . . . . . . . . . . . . . . . . . . . . . . 444

Analysis 1.1. Comparison 1 Primary outcome: quality of life, Outcome 1 All Studies. . . . . . . . . . . . . . . 45

Analysis 1.2. Comparison 1 Primary outcome: quality of life, Outcome 2 Measures of Quality of Life. . . . . . . 46

Analysis 1.3. Comparison 1 Primary outcome: quality of life, Outcome 3 Cancer Site. . . . . . . . . . . . . . . . 47

Analysis 1.4. Comparison 1 Primary outcome: quality of life, Outcome 4 Type of Intervention. . . . . . . . . . . . 48

Analysis 1.5. Comparison 1 Primary outcome: quality of life, Outcome 5 Mode of Delivery. . . . . . . . . . . . . 49

Analysis 1.6. Comparison 1 Primary outcome: quality of life, Outcome 6 Discipline of 'Trained Helper'. . . . . . 50

Analysis 2.1. Comparison 2 Risk of bias, Outcome 1 Allocation Concealment. . . . . . . . . . . . . . . . . . 51

Analysis 2.2. Comparison 2 Risk of bias, Outcome 2 Intention to Treat Analysis. . . . . . . . . . . . . . . . . . 52

Analysis 3.1. Comparison 3 Secondary outcomes, Outcome 1 General Psychological Distress. . . . . . . . . . 53

Analysis 3.2. Comparison 3 Secondary outcomes, Outcome 2 Mood Measures. . . . . . . . . . . . . . . . . . 54

ADDITIONAL TABLES . . . . . . . . . . . . . . . . . . . . . . . . . . . . . . . . . . . . . . . . . . . .

APPENDICES . . . . . . . . . . . . . . . . . . . . . . . . . . . . . . . . . . . . . . . . . . . . . .

HISTORY . . . . . . . . . . . . . . . . . . . . . . . . . . . . . . . . . . . . . . . . . . . . . . . 63

CONTRIBUTIONS OF AUTHORS . . . . . . . . . . . . . . . . . . . . . . . . . . . . . . . . . . . . . . .

DECLARATIONS OF INTEREST . . . . . . . . . . . . . . . . . . . . . . . . . . . . . . . . . . . . . 63

SOURCES OF SUPPORT . . . . . . . . . . . . . . . . . . . . . . . . . . . . . . . . . . . . . . . 64

DIFFERENCES BETWEEN PROTOCOL AND REVIEW . . . . . . . . . . . . . . . . . . . . . . . . . . . . 64

Psychosocial interventions to improve quality of life and emotional wellbeing for recently diagnosed cancer patients (Review)

Copyright $\odot 2012$ The Cochrane Collaboration. Published by John Wiley \& Sons, Ltd. 


\title{
[Intervention Review] \\ Psychosocial interventions to improve quality of life and emotional wellbeing for recently diagnosed cancer patients
}

\author{
Karen Galway ${ }^{1}$, Amanda Black ${ }^{2}$, Marie Cantwell ${ }^{3}$, Chris R Cardwell ${ }^{4}$, Moyra Mills ${ }^{5}$, Michael Donnelly ${ }^{4}$ \\ ${ }^{1}$ School of Nursing and Midwifery, Queen's University Belfast, Belfast, UK. ${ }^{2}$ Division of Cancer Epidemiology and Genetics, National \\ Cancer Institute, Bethesda, MD, USA. ${ }^{3}$ Cancer Epidemiology and Health Services Research Group, Centre for Public Health, School \\ of Medicine, Dentistry and Biomedical Sciences, Queen's University Belfast, Belfast, UK. ${ }^{4}$ Centre for Public Health, Queen's University \\ Belfast, Belfast, UK. ${ }^{5}$ Northern Health and Social Care Trust, Antrim, UK \\ Contact address: Karen Galway, School of Nursing and Midwifery, Queen's University Belfast, Medical Biology Centre, 97 Lisburn \\ Road, Belfast, Northern Ireland, BT9 7BL, UK. k.galway@qub.ac.uk.
}

Editorial group: Cochrane Gynaecological Cancer Group.

Publication status and date: New, published in Issue 11, 2012.

Review content assessed as up-to-date: 24 September 2012.

Citation: Galway K, Black A, Cantwell M, Cardwell CR, Mills M, Donnelly M. Psychosocial interventions to improve quality of life and emotional wellbeing for recently diagnosed cancer patients. Cochrane Database of Systematic Reviews 2012, Issue 11. Art. No.: CD007064. DOI: 10.1002/14651858.CD007064.pub2.

Copyright (C) 2012 The Cochrane Collaboration. Published by John Wiley \& Sons, Ltd.

\begin{abstract}
A B S T R A C T

\section{Background}

A cancer diagnosis may lead to significant psychological distress in up to $75 \%$ of cases. There is a lack of clarity about the most effective ways to address this psychological distress.
\end{abstract}

Objectives

To assess the effects of psychosocial interventions to improve quality of life (QoL) and general psychological distress in the 12-month phase following an initial cancer diagnosis.

\section{Search methods}

We searched the Cochrane Central Register of Controlled Trials (CENTRAL) (The Cochrane Library 2010, Issue 4), MEDLINE, EMBASE, and PsycINFO up to January 2011. We also searched registers of clinical trials, abstracts of scientific meetings and reference lists of included studies. Electronic searches were carried out across all primary sources of peer-reviewed publications using detailed criteria. No language restrictions were imposed.

\section{Selection criteria}

Randomised controlled trials of psychosocial interventions involving interpersonal dialogue between a 'trained helper' and individual newly diagnosed cancer patients were selected. Only trials measuring QoL and general psychological distress were included. Trials involving a combination of pharmacological therapy and interpersonal dialogue were excluded, as were trials involving couples, family members or group formats.

\section{Data collection and analysis}

Trial data were examined and selected by two authors in pairs with mediation from a third author where required. Where possible, outcome data were extracted for combining in a meta-analyses. Continuous outcomes were compared using standardised mean differences and $95 \%$ confidence intervals, using a random-effects model. The primary outcome, QoL, was examined in subgroups by outcome measurement, cancer site, theoretical basis for intervention, mode of delivery and discipline of trained helper. The secondary outcome, general psychological distress (including anxiety and depression), was examined according to specified outcome measures. 


\section{Main results}

A total of 3309 records were identified, examined and the trials subjected to selection criteria; 30 trials were included in the review. No significant effects were observed for QoL at 6-month follow up (in 9 studies, SMD 0.11; 95\% CI -0.00 to 0.22); however, a small improvement in QoL was observed when QoL was measured using cancer-specific measures (in 6 studies, SMD 0.16 ; $95 \%$ CI 0.02 to 0.30 ). General psychological distress as assessed by 'mood measures' improved also (in 8 studies, SMD - 0.81; $95 \%$ CI - 1.44 to 0.18 ), but no significant effect was observed when measures of depression or anxiety were used to assess distress (in 6 studies, depression SMD 0.12; $95 \%$ CI -0.07 to 0.31 ; in 4 studies, anxiety SMD 0.05; 95\% CI -0.13 to 0.22). Psychoeducational and nurse-delivered interventions that were administered face to face and by telephone with breast cancer patients produced small positive significant effects on QoL (in 2 studies, SMD 0.23; 95\% CI 0.04 to 0.43 ).

\section{Authors' conclusions}

The significant variation that was observed across participants, mode of delivery, discipline of 'trained helper' and intervention content makes it difficult to arrive at a firm conclusion regarding the effectiveness of psychosocial interventions for cancer patients. It can be tentatively concluded that nurse-delivered interventions comprising information combined with supportive attention may have a beneficial impact on mood in an undifferentiated population of newly diagnosed cancer patients.

\section{PLAIN LANGUAGE SUMMARY}

\section{Individual therapy for people diagnosed with cancer}

Cancer occurs in one in four of the population with over a quarter of a million people in the UK diagnosed each year (excluding nonmelanoma skin cancer). A diagnosis of cancer can be emotionally challenging. UK government policy recommends that all individuals who are diagnosed with cancer should be assessed for emotional problems and given access to appropriate psychological support services. However, the nature and content of services and their delivery is unclear. This review examines the effectiveness of individual psychosocial interventions in the first 12 months after diagnosis. The psychosocial interventions involve a 'trained helper' providing therapeutic dialogue, sometimes referred to as talking therapy, with an individual diagnosed with cancer with the aim of improving quality of life and emotional wellbeing. The review combines research data from 1249 people who took part in clinical trials to test psychosocial interventions. The results are inconclusive. No improvement in general quality of life was found, but small improvements in 'illness related' quality of life were observed. No improvements in anxiety or depression were found, but small improvements in mood were detected. Nurse-led interventions using telephone and face-to-face delivery appear to show some promise. Future research should test assessment methods designed to identify patients who may benefit from psychosocial interventions, such as patients who are at risk of emotional problems; evaluate which type of 'trained helper' is the most appropriate professional to deliver psychosocial interventions for cancer patients; and conduct economic appraisals of the cost-effectiveness of interventions.

Psychosocial interventions to improve quality of life and emotional wellbeing for recently diagnosed cancer patients (Review) 
Patient or population: newly diagnosed patients with cancer

Settings: hospital and community based settings

Intervention: psychosocial interventions

Comparison: usual care

\begin{tabular}{lll}
\hline Outcomes & $\begin{array}{l}\text { Standardised Mean Differences } \\
\mathbf{( 9 5 \% ~ C l )}\end{array}$ & $\begin{array}{l}\text { No of Participants } \\
\text { (studies) }\end{array}$ \\
\hline $\begin{array}{l}\text { Measures of Quality of Life } \\
\text { [Psychometric measures of quality of life] } \\
{[6 \text { months] }}\end{array}$ & $0.11[-0.00,0.22]$ & $\begin{array}{l}1249 \\
(9)\end{array}$ \\
\hline $\begin{array}{l}\text { General Psychological Distress } \\
\text { [Psychometric measures of general } \\
\text { chological distress] } \\
{[6 \text { months] }}\end{array}$ & $0.08[-0.05,0.21]$ & $\begin{array}{l}1502 \\
(9)\end{array}$ \\
\hline $\begin{array}{l}\text { Mood Measures } \\
\text { [Psychometric measures of mood] }\end{array}$ & $-0.81[-1.44,-0.18]$ & \\
{$[6$ months] } & & $\begin{array}{l}683 \\
(8)\end{array}$
\end{tabular}

\section{B A C K G R O U N D}

\section{Description of the condition}

Cancer has a significant impact on the lives of many people. It is experienced personally by one in four of the population and over a quarter of a million people in the UK are diagnosed with the disease each year (CRUK 2007) (excluding non-melanoma skin cancer). Cancer of the breast, colon, prostate and lung account for over $50 \%$ of cases. Due to the ongoing improvements in cancer diagnostics and clinical therapies, the prognosis for many people with cancer is improving steadily. The resulting advances in years of life gained are often achieved using invasive therapies that can lead to significant morbidity amongst patients (Weis 2003). Improvements in years or quantity of life (QoL) are now being followed, with an increasing recognition of the QoL of people with cancer and in particular the importance of giving attention to ways of maintaining and improving QoL in policy and practice $(\mathrm{DoH}$ 2004; NICE 2004).

A diagnosis of cancer can be psychologically and emotionally challenging and associated needs must be addressed appropriately. The prevalence of psychological distress amongst cancer patients is difficult to estimate and reports of psychological morbidity vary from $6 \%$ (Sellick 1999) to 75\% (Macmillan 2006) depending on the diagnostic tools and criteria. In the UK, prevalence appears to be greatest among people under 65 years and higher amongst patients seeking care through the NHS compared to patients receiving private treatment (Macmillan 2006).

The psychological and emotional impact of a cancer diagnosis can be influenced by many factors including the way in which clinicians impart a diagnosis, previous history of psychological morbidity and patient personal characteristics (Sellick 1999; Turton 2000). The most common reaction to a cancer diagnosis is emotional distress followed by a phase of taking control, which involves seeking information and sourcing appropriate help (Turton 2000). This common reaction has recently been illustrated in a survey in which $50 \%$ of cancer patients reported the need for emotional support services (Macmillan 2006). The survey also found that people affected by cancer appointed a higher priority to the need for studies on living and coping with cancer, and available support, than for research aimed at curing cancer (Macmillan 2006). Fur- 
thermore, given the complex relationship between psychological distress and clinical aspects of care such as treatment compliance and immune function, the importance of identifying and providing effective forms of emotional support is widely accepted (NCI 2007; Sellick 1999).

Key points of psychological and emotional vulnerability include the time of diagnosis, treatment endpoints and episodes of recurrence (Turton 2000), and more is being gleaned about the distress trajectories experienced according to personal and disease characteristics (Henselmans 2010). This review aims to assess the impact of interventions during the phase directly after diagnosis. However, as the chronology of the cancer journey will depend heavily on the cancer stage and site, along with numerous other patient and provider variables, it is difficult and perhaps inappropriate to specify precisely the boundaries around periods of vulnerability. Best evidence suggests that levels of depression and anxiety in cancer patients generally tend to subside after the first 12 months (Stanton 2006).

\section{Description of the intervention}

Over the past three decades a variety of individual and groupbased interventions have been developed specifically for people with cancer. Psychosocial interventions are wide ranging in terms of theoretical background, complexity, content and mode of delivery (Stanton 2006; Weis 2003). In essence, a psychosocial intervention is non-pharmacological and involves an interpersonal relationship between a patient or group of patients and one or more trained (usually professional) helpers. The psychosocial aspect includes interventions described as psychological, psychotherapeutic, psychoeducational or psychosocial (see Types of interventions below for the range of interventions that will be covered in the review).

\section{Why it is important to do this review}

Current UK government policy recommends that all patients should undergo systematic psychological assessment at key points during their cancer journey complimented by access to appropriate psychological support services (DoH 2004; NICE 2004). The National Institute for Clinical Excellence (NICE) states that there is a need for further evaluative research to "determine which psychotherapeutic interventions are most effective for different groups of patients at different stages of the patient pathway" (NICE 2004). Despite the flourishing growth of literature in this area of cancer care and the wide range of treatments available to ease symptoms of anxiety and depression, no evidence-based guidelines exist to inform methods of assessing and addressing emotional wellbeing in people during the early diagnostic phase. Previous reviews of the literature have suggested that psychosocial therapies have a positive impact on emotional adjustment, QoL, psychological distress and coping skills (Chan 2012; Edwards 2004; Jacobsen
2002; Linden 2012; Newell 2002; Sellick 1999; Stanton 2006; Weis 2003).

To date, no review focuses exclusively on the early stage of coping with a cancer diagnosis. It is also commonplace for review conclusions to be drawn tentatively due to concerns about the quality of the research methods employed when testing psychosocial interventions (Jacobsen 2008; Linden 2012; Newell 2002). Given the volume of publications that has emerged over the last decade, it was hoped that the current review would reveal a higher standard of methodology and reporting than had previously been found by review authors.

This review took account of the NICE recommendations for further research by assessing the value of psychosocial (including psychotherapeutic) interventions that have been designed to ameliorate the emotional symptoms accompanying and following a cancer diagnosis in adult cancer patients. A focused systematic review of studies in this area can help to identify appropriate service responses for cancer patients at this first stage in their cancer journey.

\section{O B J E C T I VES}

To assess the effects of psychosocial interventions to improve QoL in recently diagnosed cancer patients.

The review also assessed the effects of psychosocial interventions with recently diagnosed cancer patients to address:

- general psychological distress;

- anxiety;

- depression.

\section{MET HOD S}

\section{Criteria for considering studies for this review}

\section{Types of studies}

Randomised controlled trials (RCTs) and quasi-RCTs of psychosocial interventions with recently diagnosed adult cancer patients.

\section{Types of participants}

Adults (18+ years) who had been formally diagnosed with any type or stage of cancer within the past 12 months. 


\section{Types of interventions}

An intervention must comprise 'talking' in the form of a verbal dialogue between an individual and a trained 'helper'*. The review exclusively assessed psychosocial interventions involving interpersonal dialogue and therefore excludes interventions based solely on the following: physical therapy, that is massage; alterative therapy, that is acupuncture; educational media, that is leaflets, brochures, CDs or DVDs, or other media.

Control groups must have been free of any intervention, that is must be receiving standard care only. Trials that included other interventions combined with psychosocial interventions in the active intervention arm were excluded.

*Group and couple-based interventions were excluded. See changes made to the original scope of the review in Differences between protocol and review.

\section{Types of outcome measures}

\section{Primary outcomes}

- Quality of life (QoL)

\section{Secondary outcomes}

- General psychological distress

- Depression

- Anxiety

All outcome measures must have been assessed using a validated scale, for example: European Organisation for Research and Treatment of Cancer (EORTC) or Functional Assessment of Cancer Therapy Scales (FACT), Short Form-36 (SF-36), General Health Questionnaire-12 (GHQ-12), Beck Depression Inventory, Hospital Anxiety and Depression Scale.

\section{Search methods for identification of studies}

\section{Electronic searches}

To identify studies for inclusion in this review, detailed search strategies were developed for each of the following electronic databases:

- Cochrane Central Register of Controlled Trials

(CENTRAL) (up to January 2011);

- MEDLINE (to January 2011);

- EMBASE (to January 2011);

- CINAHL (to January 2011);

- PsycINFO (to January 2011).

The search used a combination of controlled vocabulary and free text terms in addition to the Cochrane highly sensitive search strategy for identifying reports of RCTs (Cochrane Handbook for Systematic Reviews of interventions Version.2.4.6; Appendix 5b). The search strategy was developed for MEDLINE and revised appropriately for each database. The search terms are presented in Appendix 1; Appendix 2; Appendix 3; Appendix 4.

\section{Research in progress}

The following online registers of ongoing trials were searched:

- http://controlled-trials.com;

- http://clinicaltrials.gov.

\section{Language}

No language restriction was placed on searches. Foreign language abstracts were initially translated for the application of the inclusion and exclusion criteria and, where necessary, the methods, results and discussion sections were translated for inclusion in the review.

\section{Searching other resources}

\section{Reference lists}

The reference lists of all studies were checked for further potentially relevant studies.

\section{Correspondence}

Authors of significant papers were contacted to find other potentially relevant studies and to confirm any queries.

\section{Data collection and analysis}

\section{Selection of studies}

All titles and abstracts retrieved by electronic searching were downloaded to a reference management database (Refworks) and duplicates removed. The remaining abstracts (or an extract) were examined by pairs of review authors and independently screened for applicability according to the criteria for selecting studies for this review. In situations where information about the criteria was not apparent within the abstract, the complete text was acquired and checked for eligibility. 


\section{Data extraction and management}

The review authors independently extracted data from original reports in pairs, with two authors extracting data from each study, using data extraction forms. Any disagreement was resolved by consensus between the two or, where necessary, between all the authors. Extracted data included country of origin, health professional group involved, nature and content of psychosocial intervention and patient group involved, duration of study, setting, sample size, quality and outcomes including the names of validated instruments utilised.

\section{Assessment of risk of bias in included studies}

The review authors worked in pairs to assess the methodological quality of each selected study.

\section{Random allocation}

We coded the randomisation of participants to intervention groups as:

a) adequate, e.g. computer-generated random sequence, or table of random numbers;

b) quasi-randomised, e.g. date of birth, hospital identity (ID) number or surname;

c) unclear, e.g. not reported.

\section{Allocation concealment}

We coded the concealment of allocation sequence from treatment providers and participants as:

- adequate, e.g. where the allocation sequence could not be foretold;

- inadequate, e.g. where the allocator or treatment provider could see which arm the next participant was being assigned to;

- unclear, e.g. not reported.

\section{Blinding}

Participants cannot be blinded to the intervention. However, we coded the blinding of outcome assessors as follows.

- Yes.

- No.

- Unclear.

\section{Loss to follow-up}

We recorded the number of participants in each intervention arm whose outcomes were not reported at the end of the study, and we noted whether or not loss to follow-up was reported.

\section{Assessment of reporting bias}

A funnel plot corresponding to the primary outcome was generated to assess the potential for publication bias.

\section{Data synthesis}

\section{Measures of treatment effect}

Data were entered into RevMan where standardised mean differences (SMD) and 95\% confidence intervals (CI) were calculated and pooled using a random-effects model. SMDs are the appropriate choice of measure of efficacy when different scales have been employed across trials, for example the EORTC QLQ-30, SF-36, and FACT-B.

\section{Assessment of heterogeneity}

Heterogeneity between studies was assessed using the $\mathrm{I}^{2}$ statistic. $\mathrm{I}^{2}$ greater than $50 \%$ was considered indicative of heterogeneity. Where marked heterogeneity was suspected, sources were investigated, and where excessive heterogeneity was found estimates were interpreted with caution. Random-effects models were used for all meta-analyses.

\section{Subgroup analysis}

It was intended that the effectiveness of the interventions be examined in subgroups classified by: (1) cancer site; (2) training and qualifications of intervention facilitator or 'trained helper'; (3) mode of intervention for example face to face, telephone, or a combination; (4) emotional state at the time of the intervention; and (5) stage and mode of clinical treatment programme. The review team used a descriptive typology of interventions to conduct subgroup analyses of studies by type given the wide range of interventions that can be described as psychosocial, such as cognitive behavioural therapy, psychoeducation, and other counselling approaches with an unspecified theoretical basis.

When the characteristics of data had been extracted from the selected studies, the range of psychometric measures used as primary outcome measures was recognised as qualitatively different, and therefore an important potential source of heterogeneity. In order to take this into consideration a post hoc subgroup analysis was added to examine results according to general health-related quality of life measures and illness-specific quality of life measures.

\section{Summary of findings table}

The Summary of findings for the main comparison presents the results of meta-analyses carried out on primary and secondary outcomes: QoL ( $\mathrm{n}=9$ studies), general psychological distress (anxiety, $\mathrm{n}=4$ studies; depression, $\mathrm{n}=6$ studies $)$ and $\operatorname{mood}$ measures $(\mathrm{n}=$ 8 studies). 
A brief narrative description of studies not suitable for meta analyses has been included in the results section of the review $(\mathrm{n}=$ 10 studies, plus Sandgren's pilot (Sandgren 2000) and long-term follow-up publication (Sandgren 2007)).

\section{R E S U L T S}

\section{Description of studies}

See: Characteristics of included studies.

Thirty studies were included, and an important comment should be made. Sandgren 2000 reported on a pilot study which was expanded and reported on in Sandgren 2003. The later paper, Sandgren 2007, included the long-term follow-up data. Follow- up data closest to six months were extracted where possible across all studies, so the results of the 2003 paper were selected for the meta-analyses. Therefore, 32 publications were evaluated as 30 separate studies.

\section{Results of the search}

Figure 1 illustrates the process of study selection for the review. The search of the electronic databases retrieved 3309 publications. After eliminating the duplicates, 3272 publications were identified for screening. After this initial screening, the full-text articles were retrieved for the remaining 301 potential studies. From these full-text articles 268 publications were excluded leaving 32 publications included in the review. These 268 publications were excluded for the reasons stated in the 'Excluded studies' section below, however the reason for exclusion did not become apparent until the full text of the article had been examined in detail. 
Figure I. Study flow diagram.

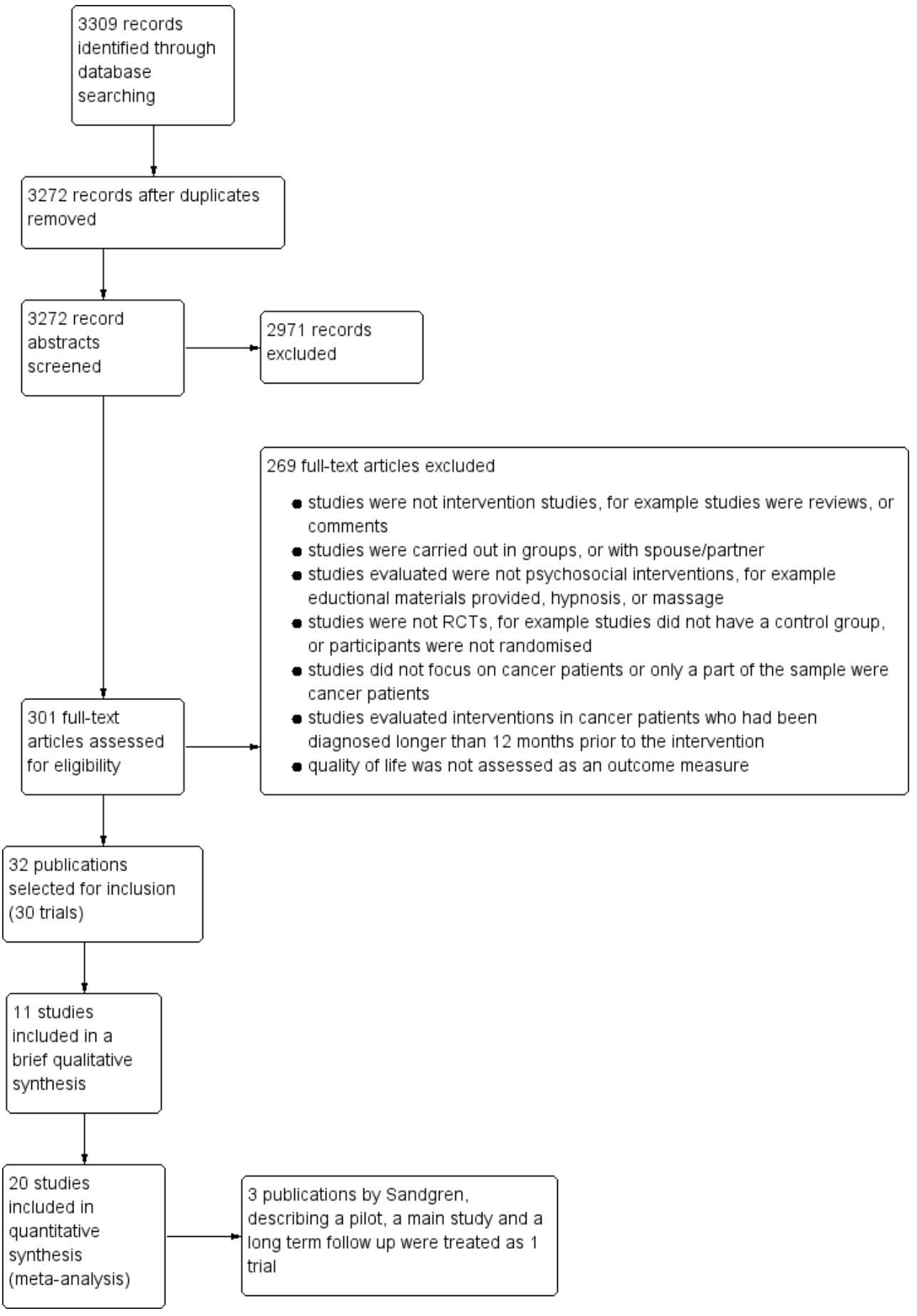

Psychosocial interventions to improve quality of life and emotional wellbeing for recently diagnosed cancer patients (Review) 


\section{Included studies}

\section{Design}

Only RCTs were included in the review. Therefore, all 30 included studies reported a baseline assessment and a post-intervention assessment. However, the total number of post-intervention assessments varied between two and eight, with a median of two. The format of reporting precluded data extraction for meta-analytic combination in 10 studies (Burton 1995; Forester 1985; Jacobsen 2002; Lee 2006; Lev 2000; Linn 1981; Mishel 2002; Ross 2005; Scura 2004; Scholten 2001).

\section{Sample sizes}

The sample size across the 30 included studies varied between 17 and 558, with a total of 5155 participants. The mean number of participants was 172. Tables 1 and 2 provide an overview of study characteristics, indicating those studies that provided appropriate data for inclusion in the meta-analyses (Table 1; Table 2).

\section{Setting}

In the context of this review, setting describes the discipline of the intervention administrator and mode of delivery. The most common discipline to administer psychosocial interventions with newly diagnosed patients was registered nurses, across 11 trials (Allard 2007; Dow Meneses 2007; Downe-Wamboldt 2007; Fawzy 1995; Lee 2006; Lev 2000; McArdle 1996; Mishel 2002; Moynihan 1998; Ross 2005; Sandgren 2003). Psychologists delivered interventions in five studies (Chan 2005; Jacobsen 2002; Johansson 2008; Nezu 2003; Scholten 2001), medical practitioners were the interventionists in four studies (Burton 1995; Forester 1985; Holtedahl 2005; Petersen 2002) and counsellors were involved in two studies (McQuellon 1998; Puig 2006). A further four interventions in studies were administered by multi-disciplinary teams of social workers, psychologists and nurses (Edgar 2001; Manne 2007; Parker 2009; Stanton 2005), one was delivered exclusively by social workers (Linn 1981), one by a researcher at PhD level (Scura 2004), and one study failed to report the discipline of the facilitator (Trask 2003).

Mode of delivery also varied across studies, with four telephone intervention studies (Allard 2007; Downe-Wamboldt 2007; Sandgren 2003; Scura 2004) and six interventions featuring a combination of face-to-face and telephone contacts supplemented by additional media such as video tapes and written manuals (Dow Meneses 2007; Johansson 2008; Lev 2000; Manne 2007; Mishel 2002; Stanton 2005). All the remaining studies utilised the most common mode of face-to-face delivery $(n=20)$. No trials of webbased interventions met the criteria for the review.

\section{Participants}

\section{Disease characteristics}

A majority of the studies focused on patients with a single site malignancy ( $\mathrm{n}=18$ ) (Allard 2007; Burton 1995; Dow Meneses 2007; Fawzy 1995; Kanzaki 2002; Lev 2000; McArdle 1996; Mishel 2002; Moynihan 1998; Parker 2009; Petersen 2002; Puig 2006; Ross 2005; Sandgren 2003; Scholten 2001; Scura 2004; Stanton 2005; Trask 2003). The remainder examining a mixed site group $(\mathrm{n}=12)$. The majority of single site studies focused on patients with breast cancer $(\mathrm{n}=9$ ) (Allard 2007; Burton 1995; Dow Meneses 2007; Lev 2000; McArdle 1996; Puig 2006; Sandgren 2003; Scholten 2001; Stanton 2005). The remainder of the single site studies focused on colon (Ross 2005), gastric (Kanzaki 2002), skin (Fawzy 1995; Trask 2003), prostate (Mishel 2002; Scura 2004), and testicular cancer (Moynihan 1998; Parker 2009). Some trials appeared to have included sites according to the speciality of the centre in which the trial took place, whereas others stated that they had included all cancers.

\section{Psychiatric selection and exclusion criteria}

Eleven trials excluded patients with a history of psychological problems (Allard 2007; Fawzy 1995; Holtedahl 2005; Kanzaki 2002; Lee 2006; Mishel 2002; Nezu 2003; Parker 2009; Petersen 2002; Stanton 2005; Trask 2003). One specified excluding those with suicidal thoughts (Moynihan 1998) and one specified excluding those with senile dementia (Ross 2005). One trial with a sample size of 200 included 40 individuals with a psychiatric history, (Burton 1995). The remaining 16 studies did not specify current or previous psychiatric conditions separately from exclusion criteria that generally referred to serious co morbidities. No screening criteria were employed with the aim of targeting interventions for pre-existing levels of distress, although all participants were subject to baseline screening of QoL or psychological distress to provide 'time 1' measures for the trials.

\section{Interventions}

In order to consider the use of pooled estimates in a systematic review, the studies need to be considered homogeneous to ensure that a combined analysis is valid. The basis on which we have approached this is founded on the principle that the effect of a psychosocial intervention is a function of the supportive relationship

Psychosocial interventions to improve quality of life and emotional wellbeing for recently diagnosed cancer patients (Review) 
between the 'trained helper' and the individual diagnosed with cancer. The supportive human interaction is present across all trials, as is the common aim to alleviate distress and improve quality of life in the event of a cancer diagnosis. It is argued that when carrying out systematic reviews, "heterogeneity should be considered the expectation as opposed to the exception [and where possible] analyses of heterogeneity should be pursued and interpreted cautiously in the spirit of an exploratory data analysis" (Berlin 1995). In the current review, features of the selected studies have been considered in this way and, to facilitate careful planning, we have uses a priori definitions and analytic strategies. Subgroup analyses examined the factors relating to the content of the interventions, the mode of delivery of interventions, the discipline of the trained helper and the types of outcome measures used. These subgroups were selected to address the variations across outcome measures, cancer site, intervention types, discipline of 'trained helper' and mode of delivery in included studies. Post hoc subgroup analyses were also carried out according to the use of general health-related QoL measures and illness-specific measures of QoL.

\section{Theoretical basis}

All the studies included some form of supportive relationship, defined by interpersonal dialogue involving a 'trained helper' and an individual participant. All group, family and couple-based interventions were excluded from the review. See Differences between protocol and review for details. The theoretical basis within the interventions varied markedly. Some were based on one or two elements, while others used multiple techniques. Fourteen studies specifically referred to Cognitive Behavioural Therapy (CBT), or to recognised techniques within that discipline (Chan 2005; Downe-Wamboldt 2007; Edgar 2001; Fawzy 1995; Johansson 2008; Kanzaki 2002; Lev 2000; Mishel 2002; Moynihan 1998; Nezu 2003; Parker 2009; Scholten 2001; Stanton 2005; Trask 2003). Eight studies described the intervention as a form of counselling (Allard 2007; Holtedahl 2005; Linn 1981; Manne 2007; McArdle 1996; Petersen 2002; Ross 2005; Sandgren 2003), including many varied techniques ranging from supportive listening to detailed, referenced intervention 'packages', such as the Attentional Focus and Symptom Management Intervention (AFSMI) (Allard 2007). Four studies took the form of brief, preparatory interventions timed immediately prior to treatment, particularly invasive procedures such as surgery (Burton 1995; Forester 1985; Jacobsen 2002; McQuellon 1998). These four used a combination of theoretical approaches including counselling, psychotherapy and relaxation techniques. Three studies were classified by the authors as psychoeducational in nature (Dow Meneses 2007; Puig 2006; Scura 2004), although art therapy played an important role in Scura 2004. Finally, a single study specified a 'meaning-making' approach (Lee 2006).

\section{Duration}

Out of the 30 studies only 21 reported a specific number of sessions delivered to the intervention group. Amongst those 21 studies the number of sessions varied from one to 10 , with a median of four sessions. The remaining nine studies reported a variety of permutations, including 'as required', 'while treatment took place'; and some stated the percentage of the intervention group who took part in more than a specified number of sessions. The length of sessions were between 10 and 90 minutes, whereas the frequency of sessions fell between 'several times a week' and 'once every two months'.

\section{Control conditions}

In one study $11 \%$ of participants were already receiving psychological interventions prior to and during the trial (Lee 2006). In another study the authors declared that a psychological assessment was part of standard care and therefore was implemented with the control group (Jacobsen 2002). In the remaining studies, the participants in the control group did not receive the intervention but received standard care and standard information on treatment.

\section{Outcomes}

Eleven studies focused on the primary outcome of QoL using validated psychometric measurement tools such as the European Organisation for Research and Treatment into Cancer Quality of Life Questionnaire-30 (EORTC QLQ-30) *(Chan 2005; Holtedahl 2005; Johansson 2008; Ross 2005), Functional Assessment of Cancer Therapy Breast/General (FACT-B/G) (Edgar 2001; Lev 2000; Sandgren 2003; Scura 2004) and SF-36 (Jacobsen 2002; Stanton 2005; Trask 2003). Three studies used less well known validated measures of QoL (Dow Meneses 2007; Linn 1981; Scholten 2001). The remaining 16 reported on general psychological state, extrapolating from the results of a wide variety (and multiple use of) of psychometric tools as a proxy measure of QoL, including Profile of Mood States (POMS), General Health Questionnaire28 (GHQ-28), Hospital Anxiety and Depression Scale (HADS), Mini-Mental State Examination (MMSE), State Trait Anxiety Inventiory (STAI), Centre for Epidemiological Studies-Depression (CES-D), Beck Depression Inventory (BDI), Rosenberg Self-Esteem Scale (RSES) and a number of other less well known validated measures. Four studies provided appropriate data for metaanalyses of the primary outcome QoL as well as the secondary outcome general psychological distress (Chan 2005; Edgar 2001; Johansson 2008; Trask 2003), whereas 11 provided data suitable for meta-analyses of the general psychological distress outcome only (Allard 2007; Downe-Wamboldt 2007; Fawzy 1995; Kanzaki 2002; Manne 2007; McArdle 1996; McQuellon 1998; Moynihan 1998; Nezu 2003; Petersen 2002; Puig 2006) and five provided data suitable for meta-analysis of QoL outcomes only (Dow Meneses 2007; Holtedahl 2005; Parker 2009; Sandgren 2003; Stanton 2005). 


\section{Excluded studies}

Reasons for excluding publications were:

- studies were not intervention studies, e.g. studies were

reviews, or comments;

- studies were carried out in groups, or with spouse or partner;

- studies evaluated were not psychosocial interventions, e.g.

educational materials provided, hypnosis, or massage;

- studies were not RCTs, e.g. studies did not have a control

group, or participants were not randomised;

- studies did not focus on cancer patients, or only a part of the sample were cancer patients;

- studies evaluated interventions in cancer patients who had

been diagnosed longer than 12 months prior to the intervention;

- studies did not focus on first diagnosis, or only part of the

sample were experiencing a first diagnosis;

- QoL was not assessed as an outcome measure.

Due to the volume of studies identified by the search, usually only the first occurrence of an exclusion criterion in the publication was noted, although it was common for studies to feature a combination of the reasons for exclusion listed above. Therefore, it was neither valid nor helpful to present the number of papers excluded under each of the reasons listed above.

The extent of exclusion at the full-paper stage (268 publications excluded from 301) provided the first indication of problems associated with quality of reporting in this research arena. Due to the high number of studies that were initially identified and subsequently excluded, it would not have been helpful to enter details of each into the 'Characteristics of excluded studies' section of this review.

\section{Risk of bias in included studies}

The results of the methodological quality assessment are described in the 'Risk of bias' tables.

The possibility of bias could be found in the characteristics of the samples. The exclusion criteria varied between the included studies, for example some studies excluded patients with co morbidities, while some studies did not describe any additional exclusion criteria. The methodological quality might also introduce bias. This is described in the discussion in more detail.

\section{Effects of interventions}

See: Summary of findings for the main comparison

The following section provides a description of the results of the meta-analytical examination of the primary outcome QoL and the secondary outcome general psychological distress. Also presented is a brief narrative description of the studies that did not present adequate data for meta-analysis.

\section{Primary outcome - quality of life (QoL)}

Eleven studies focused on the primary outcome of the review using validated measures to gauge the impact of an intervention on QoL. Nine of these provided adequate data for meta-analysis (Ross 2005 and Lev 2000 could not be included). A funnel plot corresponding to the primary outcome was generated to assess the potential for publication bias (Figure 2). There was no evidence of funnel plot asymmetry which would potentially indicate publication bias. ( Figure 3). 
Figure 2. Funnel plot of comparison: Quality of Life; all studies.

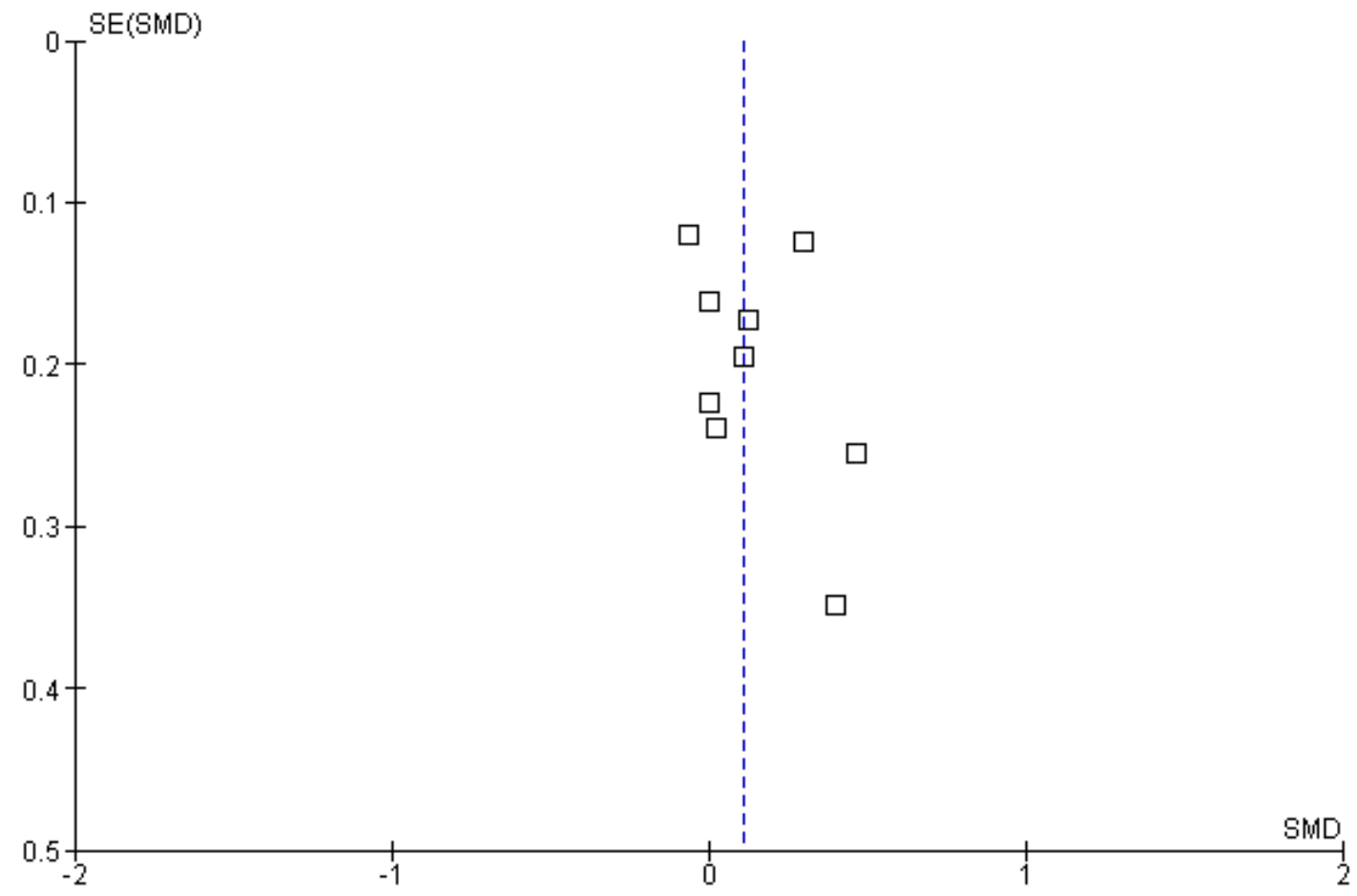

Figure 3. Risk of bias graph: review authors' judgements about each risk of bias item presented as percentages across all included studies.

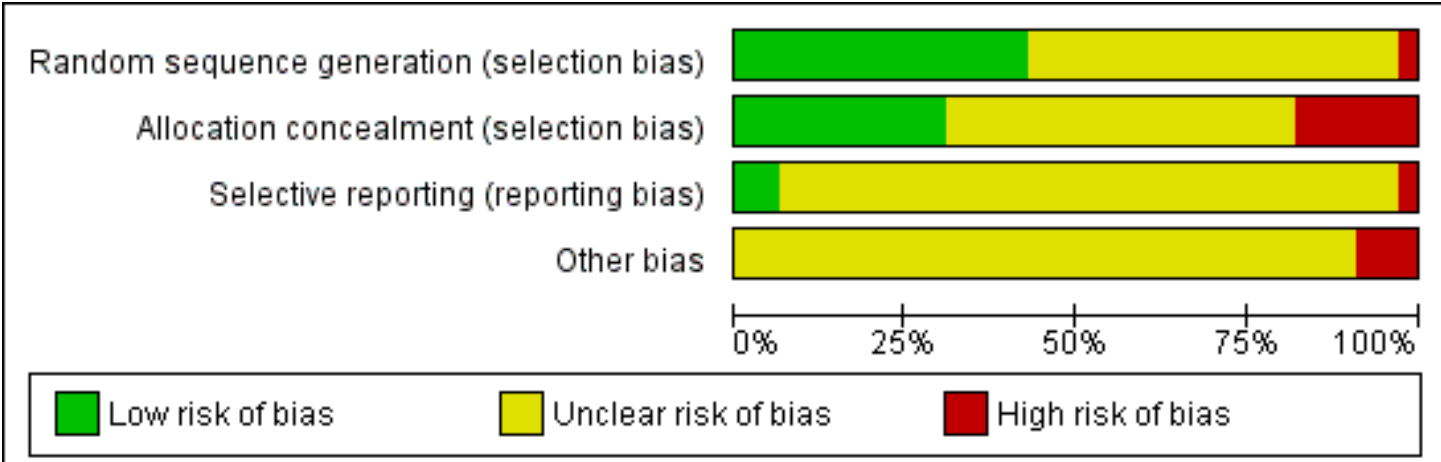

Analysis 1.1 presents the combined results for all validated measures of QoL across the reported follow-up period closest to six months (varied between four and six months) in the relevant nine studies. It clearly indicated that only one study had a significant effect on QoL (Dow Meneses 2007) and none had a large effect. Analysis at this macro-level suggests there was no clear evidence of a benefit of providing a psychosocial intervention to improve QoL 
for patients recently diagnosed with cancer (SMD 0.11; 95\% CI 0.00 to 0.22 ). There was no marked evidence of statistical heterogeneity between study estimates $\left(\mathrm{P}=0.48, \mathrm{I}^{2}=0 \%\right)$.

However, when the analysis was divided into general health-related and illness-specific QoL measures, a small but significant positive result was observed in the data utilising illness-specific measures (SMD 0.16; 95\% CI 0.02 to 0.30). The illness-specific measures used in the six combined studies were the EORTC QLQ-30, FACT-B/G, and the QoL Breast Cancer Survivors Scale. The general health measure of QoL used in the remaining three studies was the SF-36. With the use of cancer-specific QoL measures, there appeared to be evidence that supported the use of psychosocial interventions for QoL in newly diagnosed cancer patients (Analysis 1.2; Figure 4). However, the effect size was small and may not be considered clinically significant.

Figure 4. Forest plot of comparison: I Primary outcome Quality of Life, outcome: I.2 Measures of Quality of Life.

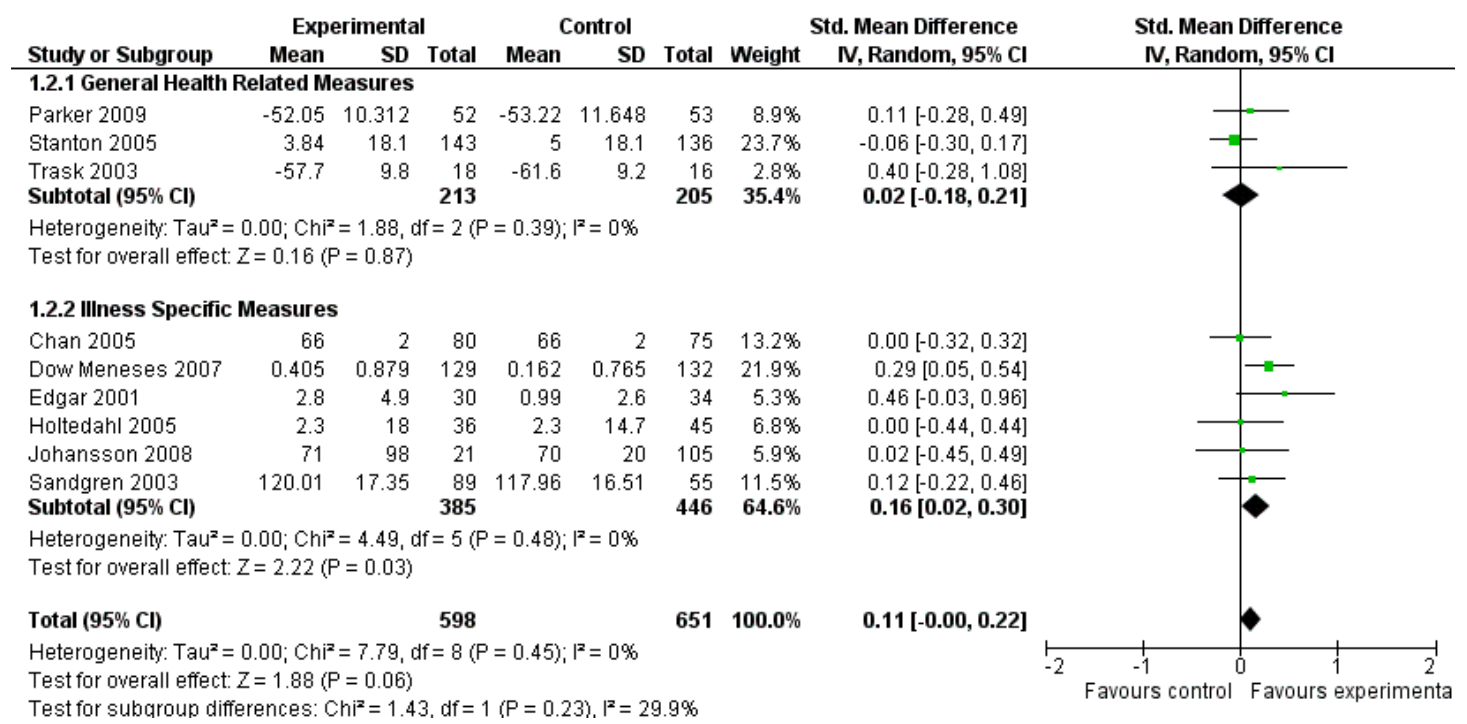

Analysis 1.3, Analysis 1.4, Analysis 1.5, Analysis 1.6 presented the results of examining the primary outcome in four subgroups according to: cancer site; theoretical basis or type of intervention; mode of delivery; and discipline of 'trained helper'. Across these subgroup analyses two significant results emerged that could indicate stronger beneficial features of interventions designed to improve QoL in newly diagnosed cancer patients, namely psychoeducational interventions and nurse-delivered interventions. Again, the effect sizes were small.

Analysis 1.4 and Figure 5 present the theoretical basis subgroup analysis, classified into counselling, CBT and psychoeducation.
Only one study was classified as primarily psychoeducational (Dow Meneses 2007), although a number of others were designed with an educational component. Although a less well known validated measure of QoL was used, the Dow Meneses et al RCT involved 261 breast cancer participants in an adequately randomised design with no indication of other methodological concerns (SMD 0.29; $95 \%$ CI 0.05 to 0.54 ). Further replication of the results would increase confidence in the conclusions about the value of a psychoeducational intervention across wider groups of cancer patients and cancer sites, particularly if they used more commonly recognised 
validated measures of QoL to promote more robust comparisons across studies.

Figure 5. Forest plot of comparison: I Primary outcome Quality of Life, outcome: I.4 Type of Intervention.

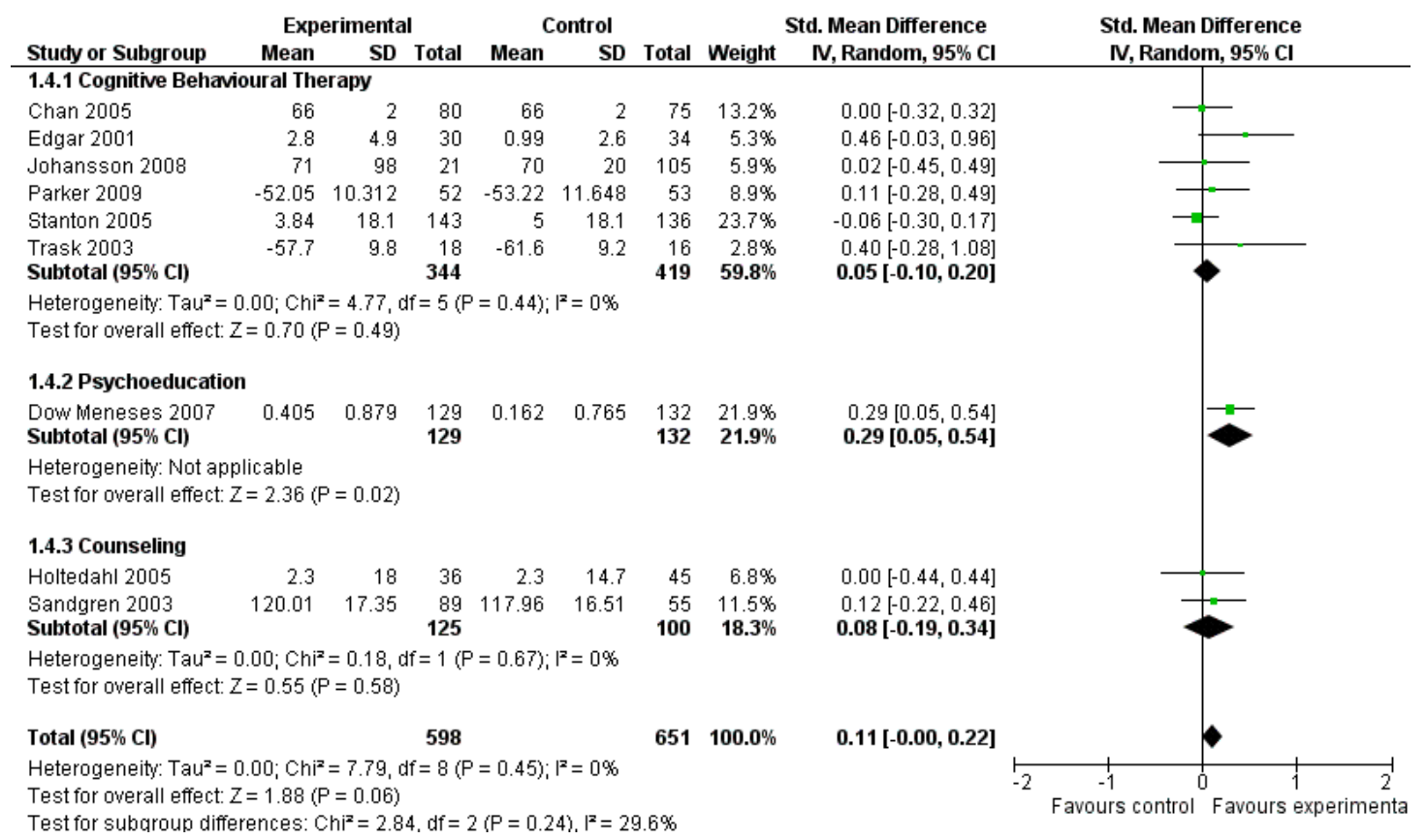

Analysis 1.6 and Figure 6 indicate positive results achieved through nurse-delivered interventions (SMD 0.23; $95 \%$ CI 0.04 to 0.43 ) in a combined analysis of two studies (Dow Meneses 2007; Sandgren 2003). The interventions involved a total of 405 participants recently diagnosed with breast cancer and receiving two distinct interventions with counselling and psychoeducational approaches. Sandgren et al delivered the intervention with six 30-minute telephone sessions whereas Dow Meneses et al used a combination of two telephone sessions and five face-to-face sessions. The followup data were collected at five and six months respectively. The effect size was small, indicating that in terms of QoL measures the impact of the interventions may only approach clinical significance. 
Figure 6. Forest plot of comparison: I Primary outcome Quality of Life, outcome: I.6 Discipline of 'Trained Helper'.

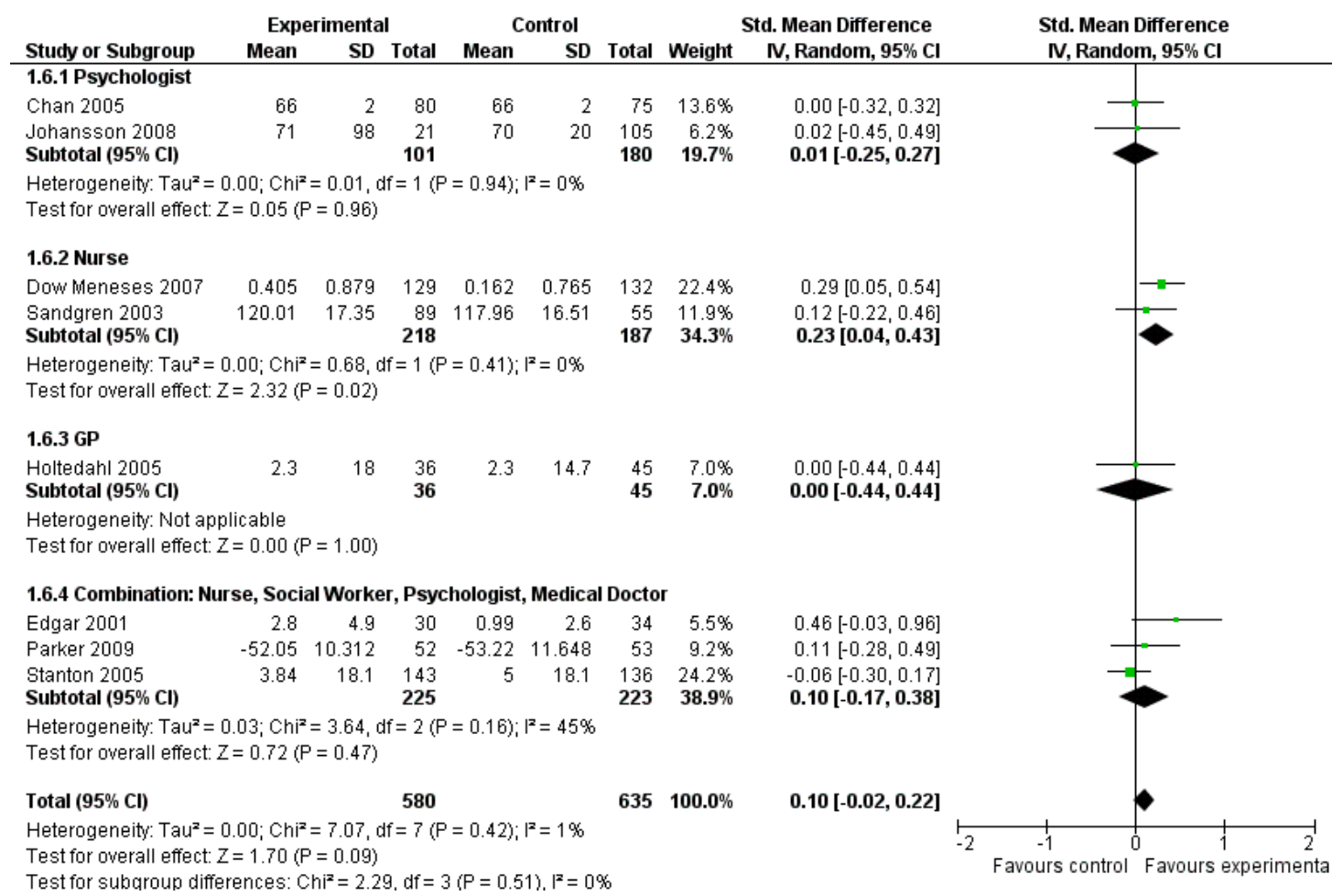

Subgroup analyses were planned for gauging the impact of emotional state at the time of the intervention and the stage and mode of the clinical treatment programme, however the studies examined did not provide adequate assessments or breakdown of results to answer these questions.

\section{Secondary outcome - general psychological distress}

Analysis 3.1 presents a combined analysis of results across 10 studies that represented general psychological distress using validated measures of depression (Chan 2005; Edgar 2001; Johansson 2008; Manne 2007; Puig 2006; Stanton 2005) and anxiety (Johansson 2008; McArdle 1996; Moynihan 1998; Trask 2003). The analysis did not provide evidence of the effectiveness of psychosocial interventions to alleviate anxiety or depression amongst newly diagnosed cancer patients. The effect sizes were not statistically significant, and statistical heterogeneity was present in the outputs of both sets of pooled estimates.

Analysis 3.2 and Figure 7 present a combined analysis of results gathered using 'mood measures'. The results indicated a significant impact of psychosocial interventions on mood (SMD -0.81; 95\% CI -1.44 of -0.18). However, the percentage variability in effect estimates that was due to heterogeneity rather than sampling error (chance) was high $\left(\mathrm{P} \leq 0.01, \mathrm{I}^{2}=93 \%\right)$. The heterogeneity found was likely to reflect differences in size and character of the patient populations examined, possible differences in the contents of the intervention, the mode of delivery or the discipline of the 'trained helper', as well as differences in the methodological quality of the different trials. However, if that was the case, we might expect heterogeneity to be high across every meta-analysis in the review. The unexplained level of heterogeneity rendered the results inconclusive. 
Figure 7. Forest plot of comparison: 3 Secondary outcomes, outcome: 3.2 Mood measures.

\begin{tabular}{|c|c|c|c|c|c|c|c|c|c|c|c|}
\hline \multirow[b]{2}{*}{ Study or Subgroup } & \multicolumn{3}{|c|}{ Experimental } & \multicolumn{3}{|c|}{ Contol } & \multicolumn{3}{|c|}{ Std. Mean Difference } & \multirow{2}{*}{\multicolumn{2}{|c|}{$\begin{array}{c}\text { Std. Mean Difference } \\
\text { IV, Random, 95\% Cl }\end{array}$}} \\
\hline & Mean & SD & Total & Mean & SD & Total & Weight & N, Random, $95 \% \mathrm{Cl}$ & Year & & \\
\hline Fawry 1995 & 42.96 & 4.38 & 29 & 54.5 & 4.08 & 33 & $11.8 \%$ & $-2.70[-3.40,-2.00]$ & 1995 & - & \\
\hline McQuellon 1998 & 6.2 & 7.1 & 66 & 15.5 & 10.1 & 71 & $13.2 \%$ & $-1.05[-1.41,-0.69]$ & 1998 & & \\
\hline Petersen 2002 & -9.17 & 7.2 & 24 & -2.04 & 7.9 & 26 & $12.3 \%$ & $-0.93[-1.51,-0.34]$ & 2002 & & \\
\hline Kanzaki 2002 & 26 & 7.3 & 9 & 29.2 & 10.1 & 11 & $10.8 \%$ & $-0.34[-1.23,0.55]$ & 2002 & & 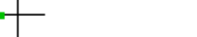 \\
\hline Sandgren 2003 & 16.28 & 32.2 & 89 & 19.5 & 30.6 & 55 & $13.3 \%$ & $-0.10[-0.44,0.24]$ & 2003 & & 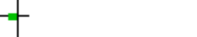 \\
\hline Total $(95 \% \mathrm{Cl})$ & & & 353 & & & 330 & $100.0 \%$ & $-0.81[-1.44,-0.18]$ & & & \\
\hline $\begin{array}{l}\text { Heterogeneity: Tau }{ }^{2} \\
\text { Test for overall effec }\end{array}$ & $\begin{array}{l}0.75 ; C \\
Z=2.51\end{array}$ & $\begin{array}{l}h i^{2}=99 \\
(P=0 .\end{array}$ & $18, d f=$ & $=7(\mathrm{P}$ & 0.0000 & 1); $\left.\right|^{2}=$ & $93 \%$ & & & $\begin{array}{lc}-4 & -2 \\
\text { avours experime }\end{array}$ & 0 Favours control \\
\hline
\end{tabular}

\section{Risk of bias}

No-significant findings were revealed by analysing the combined results according to study quality, either by examining the use of intention- to treat (ITT) analyses or by risk of bias measures (Analysis 2.1).

\section{Brief narrative description of studies not suitable for meta analyses}

- Burton 1995 (preparation for surgery): although the GHQ28 Goldberg 1978 and HADS Zigmond 1983 measures were used, the figures presented in the results section were inadequate for combination in meta analyses. Two 30-minute psychotherapeutic interventions were delivered prior to mastectomy and after the operation. Results based on case-ness and mean score on GHQ-28 and HADS were not significantly different across intervention and control groups. However, the authors reported that the rate of declining participation was $33 \%$. They pointed out that many older patients actively expressed a wish to avoid discussion of emotional need, therefore it may be useful to screen for emotional need prior to introducing psychotherapeutic interventions (null result).

- Forester 1985 (preparation for surgery): no self-report measures were presented, only results of the clinician administered diagnostic scale Schedule of Affective Disorders and Schizophrenia (SADS) (Endicott 1978). The SADS results indicated that a one-week psychotherapeutic course significantly reduced emotional and physical manifestations of distress in the intervention group compared to the control group over the course of radiotherapy treatment (positive result).

- Jacobsen 2002: change scores were presented graphically making it impossible to extract accurate data for inclusion in meta-analyses. The results indicated that a self-administered stress management training intervention improved QoL during chemotherapy treatment, measured with the SF-36. However, the professionally-administered intervention produced no significant differences when compared to the control group (positive result with self-administration or 'trained helper').

- Lee 2006: participants received four sessions of individual therapy in the form of a meaning making intervention.

Outcomes measured included self esteem (Rosenberg SelfEsteem Scale), optimism (Life Orientation Test) and Generalised Self Efficacy (GSES). None of these measures alone are comparable to QoL, anxiety, depression or general psychological distress and therefore could not be combined in a meta-analysis. Significant improvements were found across each scale measured within the experimental group compared to the control group (positive result).

- Lev 2000: although the well validated FACT was employed to measure the primary outcomes, the results were not presented in a format suitable for meta-analysis (only interaction effect sizes were presented). The results suggested that interventions to promote self-efficacy increased QoL and decreased symptom distress for women diagnosed with breast cancer (positive result).

- Linn 1981: although a number of validated scales were used, no figures were presented that could be extracted for metaanalyses. Results indicated that response to counselling in recently diagnosed late stage terminal cancer was positive in both younger and older patients (positive result).

- Mishel 2002: the outcomes included a sub scale of a QoL measure devised for use in cancer patients by the Southwest Oncology Group. The other outcomes were not appropriate for combining with QoL, general psychological distress, anxiety or depression measures. Although there was a suggestion of a trend towards a positive impact of the nurse-delivered psychoeducational intervention, the authors stated that replication would be required prior to making any firm conclusions on psychoeducational telephone interventions for men with prostate cancer (null result).

- Ross 2005: the authors presented only figures representing the difference between the intervention and control group on both HADS and EORTC QLQ-30 without number of 
participants, standard deviation or change scores; therefore, it was not possible to extract data for meta-analyses. The results suggested that a set of 10 unstructured home visits by a doctor or nurse for approximately 60 minutes had no significant impact on wellbeing. The authors recommended screening for baseline levels of distress as well as the use of trained therapists delivering short, more intensive interventions (null result).

- Sandgren 2000 and Sandgren 2007: in 2000 the authors carried out a pilot study; the results were excluded from the meta-analyses in favour of the data produced during their main trial in 2003. The 2007 publication presented the long-term follow-up data from the 2003 study. Outcomes recorded closest to six months after the intervention were selected from all included publications for combining in the meta-analyses.

- Scholten 2001: results were presented in two categories representing non-health related and health-related QoL, using a measure based on an unvalidated visual analogue scale. The findings provided support for early psychosocial counselling in newly diagnosed patients and conversely showed that the acceptance of such interventions later in the disease trajectory was low (positive result).

- Scura 2004: this pilot study of telephone social support counselling over 12 months in men within four weeks of a prostate cancer diagnosis found no significant difference in QoL scores between the intervention and control groups. Only 17 participants were involved, and it was deemed appropriate to exclude the results of any such small scale pilot study from the meta-analyses. The qualitative findings indicated that the participants found the information and social support useful for coping with both the diagnosis and subsequent treatment (trial data null result; qualitative data positive result).

\section{Summary of results}

Small significant positive QoL effects were observed when data across individual RCTs were combined. The analysis suggested that psychosocial interventions exerted a positive impact on the cancer-related QoL of newly diagnosed cancer patients compared to cancer patients who received standard care. However, the effects were not significant when generic measures of quality of life were employed.

A small statistically significant effect was observed when the results of mood measures across trials were combined. The results for the effects of psychoeducational interventions and for nurse-delivered interventions (using face-to-face and telephone delivery) indicated the most promising results. It is important to note, however, that the high level of statistical heterogeneity rendered the mood results inconclusive.

These results should be interpreted with caution for two main reasons. Firstly, the effect sizes were small; and secondly, the RCTs included in the review were not entirely homogenous. There were differences in the size and character of the patient populations; in the content of the intervention, the mode of delivery and the discipline of the 'trained helper'; as well as in the methodological quality of the different trials. The high level of observed variation presented challenges in terms of conducting a synthesis of populations, interventions and outcomes, and coming to a clear statement about effectiveness.

\section{DISCUSSION}

The findings indicate that, to date, there is a lack of convincing evidence to support universal implementation of individual therapeutic psychosocial interventions that are designed to improve the general QoL of newly diagnosed cancer patients. Psychosocial interventions exerted beneficial effects as measured by illnessspecific measures of quality of life (SMD $0.16 ; 95 \%$ CI 0.02 to 0.30 ) and by measures of mood (SMD $-0.81 ; 95 \%$ CI -1.44 to $0.18)$. However, the combined effect sizes were small and may not be considered clinically significant. There was notable variation in the style and delivery of psychosocial interventions and the statistically combined results may be susceptible to criticism in terms of the high level heterogeneity. Heterogeneity across the type of intervention, mode of delivery and discipline of 'trained helper' presented challenges to the review process despite the combined estimates for the primary outcome QoL indicating no significant statistical heterogeneity. Overall, the results suggested that psychosocial interventions add value to cancer care, though more rigorous research is required.

\section{Participants or population examined}

It was not possible to analyse subgroups of patients (for example by gender, age, previous mental health conditions or attitudes towards help seeking) due to the limited detail provided in the trial publications included in the review. Cancer is a condition that generally effects older populations, so age at intervention should be considered in assessments of the impact of interventions. Older patients are reported to experience less 'perceived' need to explore emotional reactions to cancer (Burton 1995). Therefore, they may not be offered psychosocial interventions or indeed may not be considered to benefit from them in the same way as those who are more likely to seek help, such as younger patients and those who experience higher levels of cancer-related distress (Campbell 2004; Grande 2006; Owen 2007). Additionally, those with a history of serious illness or those who are aware of genetic cancer risks have a higher risk of distress after a cancer diagnosis (Montgomery 2010) and, therefore, may benefit more from supportive interventions. Individuals who expect psychosocial support to be helpful and who feel that other people in their lives would expect them to use such services are more likely to seek support (Steginga 2008). Research is required to ascertain the potential impact of attitudes towards help seeking on psychosocial outcomes (Weich 2007). 
People with previous emotional instability, especially if they have sought help to cope with their emotions, are likely to benefit most from psychosocial interventions. In a recent review of the evidence, the chronically anxious tended to display more anxiety after diagnosis (Montgomery 2010). It was not possible to examine these subgroups in the current review because the majority of trials excluded anyone with a previous diagnosis of mental illness and no author reported results separately for patients who had availed themselves of psychosocial support in the past. In this review it was not possible to analyse results by age, levels of distress or attitudes towards help seeking for emotional problems due to a lack of relevant data.

\section{Discipline of trained helper}

Nurse-delivered interventions appear to show promise in producing a positive impact on QoL (SMD 0.23; 95\% CI 0.04 to 0.43 ). This may be due to a number of interconnected factors. Firstly, asking for psychological support is still considered to involve an element of stigma, as indicated by negative attitudes towards help seeking for depression in primary care (Weich 2007); but nursing staff can offer psychological support as part of a package of cancer care, allowing patients to avoid any perceived stigma attached to seeking additional help for emotional concerns. Secondly, psychosocially trained nurses bring specific knowledge from their biomedical training and their cancer nursing specialism to the role of psychosocial support agent (Arving 2011). Therefore, an intervention delivered by a psychosocial nurse may bring something unique to a psychosocial intervention in cancer care, which cannot be delivered by a social worker or a psychologist (Arving 2011).

\section{Type of intervention}

The promising nature of the results examining psychoeducational interventions may be related to the value of knowledge in times of extreme uncertainty. Psychoeducational interventions specifically address emotional concerns arising from the distress that can be caused by being overwhelmed or confused (with, for example, medical terminology, treatment options, side effects, prognosis and how to process and discuss all of the above with loved ones). "Women [with breast cancer] who are adequately informed about the process experience less psychological distress. However, in many studies, the majority of the women reported needing increased educational support, including written information and the availability of access to a healthcare provider" (Montgomery 2010).

\section{Measurement tools}

The current review examines results based on validated measures of QoL and psychological distress (including anxiety, depression and mood measures). No significant effect was observed with generic
QoL tools in contrast to the cancer-specific measures, which indicated tentatively that psychosocial interventions improve QoL; and the analysis of secondary outcome measures indicated that psychosocial interventions improve mood. The results may suggest that generic measures of QoL are not sufficiently sensitive to capture change and that future studies and reviews should focus on cancer-specific measures or psychological measures that have been tried and tested with cancer populations.

Inevitably, cancer impacts on an individual's QoL, both physically and emotionally. Cancer-specific measures of QoL assess the impact of cancer and its treatment and, therefore, are designed to be sensitive to cancer-related changes. Equally when interventions are planned within a population that is effectively free of formal psychiatric morbidity we might not expect measures of clinical anxiety and depression to be as sensitive as measures of mood (which are validated across a healthy population). This problem has been discussed in relevant recent meta-reviews of psychosocial interventions in cancer patients (Jacobsen 2008; Linden 2012) and it is a recognised gap in the cancer care research trial literature. The vast majority of trials measure the impact of a psychosocial intervention on distress in a given population, a proportion of whom are not experiencing distress. This approach appears to significantly dilute the treatment effects of psychosocial interventions across trial populations (Linden 2012).

A recent study of psychosocial adjustment amongst cancer survivors concluded that despite the increased risk of psychological disturbance in cancer survivors, which paradoxically tends to be more pronounced in younger patients, cancer survivors can also show increased resilience in other domains of psychosocial adjustment thought to be related to post-traumatic growth, such as social wellbeing, spirituality and personal growth (Constanzo 2009). For these reasons, the appropriateness and sensitivity of measures used to assess risk and outcomes form a critical element of any RCT designed to test the effectiveness of psychosocial support for cancer patients.

\section{A U THORS, CONCLUSIONS Implications for practice}

The review suggests tentatively that nurse-led interventions delivered in person or by telephone could provide valuable improvements in illness-specific QoL and mood, as part of a package of cancer care. However, currently there is not enough evidence to support universal application for all patients. Risk screening is required to identify and target patients who are at most risk of emotional difficulties and, therefore, most in need of support, along with consideration of a range of possible intervention types to suit identified need. The use of tiered intervention approaches in response to strategic periodic risk screening to identify levels of need is recommended in the international guidelines for psycho-oncology (Coleman 2011). Oncology teams may benefit from consid- 
ering and assessing the economic and practical viability of formalising psychosocial support provision as part of the role of specialist cancer nurses within existing health service structures.

\section{Implications for research}

A key finding of the review is that existing comorbidity and risk assessment have not been robustly explored in the RCT context, making this an obvious next step in developing advanced research knowledge about appropriate services that can fulfil the existing NICE guidelines and emerging international psycho-oncology practice guidelines for supporting cancer patients at the time of diagnosis.

Research trials identified for this review targeted patients according to cancer diagnosis alone, rather than primarily considering patients' perceived need for support. Randomised controlled trials testing psychosocial interventions that are targeted according to need in newly diagnosed cancer patients are lacking. It is necessary to improve the evidence based on need, that is, based on what works for people experiencing increased levels of distress. This approach would help to reduce the potential for measurement 'floor effects', in those who are not experiencing distress, to dilute the observed effects of psychosocial interventions.

The varied quality of reporting has led to difficulties identifying and classifying studies, due to the wide ranging variations in terminology that is used interchangeably in the field of psychosocial support. There is a need to agree upon common definitions of psychological distress and psychosocial interventions and impose the use of the conventions set out in the CONSORT statement (CONSORT 2010). Jacobsen and Jim have outlined a typology that could form the basis for consistency across future work on psychosocial interventions (Jacobsen 2008). Future studies should report on all validated measures in terms of summary measure results (rather than single subscales which are less valid and not directly comparable with summary scores).

In the fields of psychological, psychosocial and social care research it is particularly important that publishers remain mindful of the need for authors to provide results according to gender and age, given the documented gender differences seen in accessing psy- chosocial cancer support (Krizek 1999) and the general lack of gender-specific or age-specific results presented in the trials included in the present review (with the exception of intervention trials carried out with gender-specific cancers such as breast cancer).

The measurement of outcomes is more complex in psychosocial research than in most drug-based studies and clinical measures. However, the increasing number of publications of psychosocial interventions indicates this is an area of huge interest that is gaining increased support from funding bodies. A key feature of the RCT methodology design is the aspect of blinding, but a placebo cannot be effectively administered in trials of psychosocial interventions. Blinding outcome assessors would add to the rigour of the research in this field. Additional insights might be gained by generating synthesised qualitative accounts of the impact of interventions. The development of effective ways to combine mixed qualitative and quantitative data in systematic review terms is in its infancy (Hannes 2012). Future RCT work in this field should address more specific populations based on need; and provide high quality reporting standards.

\section{ACKNOWLEDGEMENTS}

The authors would like to thank the following people who provided support at various stages of the review process.

Gail Quinn, Managing Editor and Jane Hayes, Trials Search Coordinator (TSC), both at the Cochrane Gynaecological Cancer Review Group (CGCRG).

Dr Lesley Smith, Principal Lecturer Quantitative Research Methods, Department of Social Work and public Health, Oxford Brookes University.

Alex Mcllroy, Librarian, The Medical Library, Queen's University Belfast, Belfast, Northern Ireland.

Siobhan McHaffie, Volunteer Research Assistant, Niamh (Northern Ireland Association for Mental Health).

\section{REF ER E N C E S}

\section{References to studies included in this review}

Allard 2007 \{published data only\}

Allard NC. Day surgery for breast cancer: effects of a psychoeducational telephone intervention on functional status and emotional distress. Oncology Nursing Forum 2007;34(1):133-41.

Burton 1995 \{published data only\}

Burton MV, Parker RW, Farrell A, Bailey D, Connelly J,
Booth S, et al.A randomized controlled trial of preoperative psychological preparation for mastectomy. Psycho-Oncology 1995;4(1):1-19.

Chan 2005 \{published data only\} Chan YM, Lee PW, Fong DY, Fung AS, Wu LY, Choi AY, et al.Effect of individual psychological intervention in Chinese women with gynecologic malignancy: a randomized controlled trial. Journal of Clinical Oncology 2005;23(22): 4913-24. 
Dow Meneses 2007 \{published data only\}

Meneses KD, McNees P, Loerzel VW, Su X, Zhang Y,

Hassey LA. Transition from treatment to survivorship: effects of a psychoeducational intervention on quality of life in breast cancer survivors. Oncology Nursing Forum 2007; 34(5):1007-16.

Downe-Wamboldt 2007 \{published data only\}

Downe-Wamboldt BL, Butler LJ, Melanson PM, Coulter LA, Singleton JF, Keefe JM, et al.The effects and expense of augmenting usual cancer clinic care with telephone problem-solving counseling. Cancer Nursing 2007;30(6): 441-53.

Edgar 2001 \{published data only\}

Edgar L, Rosberger Z, Collet JP. Lessons learned: Outcomes and methodology of a coping skills intervention trial comparing individual and group formats for patients with cancer. International Journal of Psychiatry in Medicine 2001; 31(3):289-304.

Fawzy 1995 \{published data only\} Fawzy NW. A psychoeducational nursing intervention to enhance coping and affective state in newly diagnosed malignant melanoma patients. Cancer Nursing 1995;18(6): 427-38.

Forester 1985 \{published data only\} Forester B, Kornfeld DS, Fleiss JL. Psychotherapy during radiotherapy: effects on emotional and physical distress. American Journal of Psychiatry 1985;142(1):22-7.

Holtedahl 2005 \{published data only\}

Holtedahl K, Norum J, Anvik T, Richardsen E. Do cancer patients benefit from short-term contact with a general practitioner following cancer treatment? A randomised controlled study. Supportive Care in Cancer 2005;13(11): 949-56.

Jacobsen 2002 \{published data only\}

Jacobsen PB, Meade CD, Stein KD, Chirikos TN, Small BJ, Ruckdeschel JC. Efficacy and costs of two forms of stress management training for cancer patients undergoing chemotherapy. Journal of Clinical Oncology 2002;20(12): 2851-62.

Johansson 2008 \{published data only\}

Johansson B, Brandberg Y, Hellborn M, Persson C, Petersson L-M, Berglund G, Gilmeius B. Health-related quality of life and distress in cancer patients: results of a large randomised study. British Journal of Cancer 2008;99: 1975-83.

Kanzaki 2002 \{published data only\}

H Kanzaki, Y Kido. [Cognitive-behavioral interventions for gastrectomy patients with the early stage of gastric cancer -- weekly counseling and journal writing targeted to selfefficacy and psychological stress]. [Japanese]. Nihon Kango Kagakkai Shi [Journal of Japan Academy of Nursing Science] 2002;22:1-10.

Lee 2006 \{published data only\}

Lee V, Cohen SR, Edgar L, Laizner AM, Gagnon AJ. Meaning-making intervention during breast or colorectal cancer treatment improves self-esteem, optimism, and selfefficacy. Social Science \& Medicine 2006;62 (12):3133-45.

Lev 2000 \{published data only\}

Lev EL, Owen SV. Counseling women with breast cancer using principles developed by Albert Bandura. Perspectives in Psychiatric Care 2000;36(4):131-8.

Linn 1981 \{published data only\}

Linn BS, Linn MW. Late stage cancer patients: age differences in their psychophysical status and response to counseling. Journal of gerontology 1981;36(6):689-92.

Manne 2007 \{published data only\}

Manne SL, Edelson M, Bergman C, Carlson J, Rubin S, Rosenblum N, et al.Coping and communication-enhancing intervention versus supportive counselling for women diagnosed with gynecological cancers. Journal of Counselling and Clinical Psychology 2007;75(4):615-28.

McArdle 1996 \{published data only\} McArdle JMC, George WD, McArdle CS, Smith DC, Moodle AR, Hughson AMV, Murray GD. Psychological support for patients undergoing breast cancer surgery: a randomised study. BMJ 1996;312:813-6.

McQuellon 1998 \{published data only\} McQuellon RP, Wells M, Hoffman S, Craven B, Russell G, Cruz J, et al.Reducing distress in cancer patients with an orientation program. Psycho-Oncology 1998;7(3):207-17.

Mishel 2002 \{published data only\}

Mishel MH, Belyea M, Germino BB, Stewart JL, Bailey $\mathrm{DE}$, Robertson $\mathrm{C}$, et al.Helping patients with localized prostate carcinoma manage uncertainty and treatment side effects: nurse-delivered psychoeducational intervention over the telephone. Cancer 2002;94(6):1854-66.

Moynihan 1998 \{published data only\} Moynihan C, Bliss J M, Davidson J, Burchell L, Horwich A. Evaluation of adjuvant psychological therapy in patients with testicular cancer: randomised controlled trial. $B M J$ 1998;316(7129):429-35.

Nezu 2003 \{published data only\}

Nezu AM, Nezu CM, Felgoise SH, McClure KS, Houts PS. Project Genesis: assessing the efficacy of problem-solving therapy for distressed adult cancer patients. Journal of Consulting \& Clinical Psychology 2003;71(6):1036-48.

Parker 2009 \{published data only\}

Parker PA, Pettaway CA, Babaian RJ, Pisters LL, Miles $\mathrm{B}$, Fortier A, et al.The effects of a presurgical stress management intervention for men with prostate cancer undergoing radical prostatectomy. Journal of Clinical Oncology 2009;27(19):3169-76.

Petersen 2002 \{published data only\}

Petersen RW, Quinlivan JA. Preventing anxiety and depression in gynaecological cancer: a randomised controlled trial. BJOG: an international journal of obstetrics and gynaecology 2002;109(4):386-94.

Pitcheathly 2008 \{published data only\} Pitcheathly C, Maguire P, Fletcher I, Parle M, Tomenson B, Creed F. Can a brief psychological interevntion prevent 
anxiety or depressive disorders in cancer patients? A randomised controlled trial. Annals of Oncology 2009;20: $928-34$.

Puig 2006 \{published data only\}

Puig A, Lee SM, Goodwin L, Sherrard PAD. The efficacy of creative arts therapies to enhance emotional expression, spirituality, and psychological well-being of newly diagnosed Stage I and Stage II breast cancer patients: A preliminary study. Arts in Psychotherapy 2006;33(3):218-28.

Ross 2005 \{published data only\}

Ross L, Thomsen BL, Karlsen RV, Boesen EH, Johansen C. A randomized psychosocial intervention study on the effect of home visits on the well-being of Danish colorectal cancer patients--the INCA Project. Psycho-Oncology 2005;14(11): 949-61.

Sandgren 2000 \{published data only\}

Sandgren AK, McCaul KD, King B, O’Donnell S, Foreman G. Telephone therapy for patients with breast cancer. Oncology Nursing Forum 2000;27(4):683-8.

Sandgren 2003 \{published data only\} Sandgren AK, McCaul KD. Short-term effects of telephone therapy for breast cancer patients. Health Psychology 2003; 22(3):310-5.

Sandgren 2007 \{published data only\} Sandgren AK, McCaul KD. Long-term telephone therapy outcomes for breast cancer patients. Psycho-Oncology 2007; 16(1):38-47.

Scholten 2001 \{published data only\} Scholten C, Weinländer G, Krainer M, Frischenschlager O, Zielinski CC. Difference in patient's acceptance of early versus late initiation of psychosocial support in breast cancer. Supportive Care in Cancer 2001;9(6):459-64.

Scura 2004 \{published data only\} Scura KW, Budin W, Garfing E. Telephone social support and education for adaptation to prostate cancer: a pilot study. Oncology Nursing Forum 2004;31(2):335-8.

Stanton 2005 \{published data only\} Stanton AL, Ganz PA, Kwan L, Meyerowitz BE, Bower JE, Krupnick JL, et al.Outcomes from the Moving Beyond Cancer psychoeducational, randomized, controlled trial with breast cancer patients. Journal of Clinical Oncology 2005;23(25):6009-18.

Trask 2003 \{published data only\} Trask PC, Paterson AG, Griffith KA, Riba MB, Schwartz JL. Cognitive-behavioral intervention for distress in patients with melanoma: comparison with standard medical care and impact on quality of life. Cancer 2003;98(4):854-64.

\section{Additional references}

\section{Arving 2011}

Arving C, Holmström I. Creating a new profession in cancer nursing? Experiences of working as a psychosocial nurse in cancer care. Journal of Clinical Nursing 2011;20:2939-47.
Berlin 1995

Berlin JA. Benefits of heterogeneity in meta-analysis of data from epidemiologic studies. American Journal of Epidemiology 1995;142(4):383-7.

\section{Campbell 2004}

Campbell HS, Phaneuf MR, Deane K. Cancer peer support programs: do they work?. Patient Education and Counseling 2004;55:3-15.

\section{Chan 2012}

Chan R, Webster J, Marquart L. A systematic review: The effects of orientation programs for cancer patients and their family/carers. International Journal of Nursing Studies 2012; Early Online View doi:10.1016/j.ijnurstu.2012.03.002.

\section{Coleman 2011}

Coleman N, Hession N, Connolly A. Psycho-oncology best practice guidelines and a service perspective:conceptualising the fit and towards bridging the gap. The Irish Journal of Psychology 2011;32(1-2):72-89.

\section{CONSORT 2010}

CONSORT. CONSORT Statement. www.consortstatement.org Accessed 5th May 2012.

\section{Constanzo 2009}

Costanzo ES, Ryff CD, Singer BH. Psychosocial adjustment among cancer survivors: Findings from a national survey of health and well-being. Health Psychology 2009;28(2): $147-56$.

\section{CRUK 2007}

Cancer Research UK. UK Cancer Incidence Statistics. www.cancerresearchuk.org Accessed 31st May 2007.

\section{DoH 2004}

The NHS Cancer Plan and the new NHS: Providing a patient-centred service. Department of Health 2004:25.

\section{Edwards 2004}

Edwards AGK, Hailey S, Maxwell M. Psychological interventions for women with metastatic breast cancer. Cochrane Database of Systematic Reviews 2004, Issue 10.1002/14651858.CD004253. [DOI: 10.1002/ 14651858.CD004253]

\section{Grande 2006} Grande GE, Myers 1B, Sutton SR. How do patients who participate in support groups differ from those who do not? . Psycho-Oncology 2006;15:321-33.

\section{Hannes 2012}

Hannes K, Lockwood C. Synthesizing qualitative research: choosing the right approach. Oxford: Wiley-Blackwell, 2012.

Henselmans 2010 Henselmans I, Helgeson VS, Seltman H, de Vries J, Sanderman R, Ranchor AV. Identification and prediction of distress trajectories in the first year after a breast cancer diagnosis. Health Psychology 2010;29(2):160-8.

\section{Jacobsen 2008} Jacobsen PB, Jim HS. Psychosocial interventions for anxiety and depression in adult cancer patients: achievements and challenges. CA: a Cancer Journal for Clinicians 2008;58: 214-30. 


\section{Krizek 1999}

Krizek C, Roberts C, Ragan R, Ferrara JJ, Lord B. Gender and cancer support group participation. Cancer Practice 1999;7(2):86-92.

\section{Linden 2012}

Linden W, Grigis A. Psychological treatment outcomes for cancer patients: what do meta-analyses tell us about distress reduction?. Psycho-Oncology 2012;21:343-50.

\section{Macmillan 2006}

Macmillan Cancer Support. Worried sick: the emotional impact of cancer. Report on survey carried out by Opinion Leader Research 2006.

\section{Montgomery 2010}

Montgomery M, McCrone SH. Psychological distress associated with the diagnostic phase for suspected breast cancer: systematic review. Journal of Advanced Nursing 2010;66(11):2372-90.

\section{NCI 2007}

National Cancer Institute. Fact Sheet: Psychological Stress and Cancer. www.cancer.gov Accessed 29th May 2007.

\section{Newell 2002}

Newell SA, Sanson-Fisher WR, Salvolainen NJ. Systematic review of psychological therapies for cancer patients: Overview and recommendations for future research. Journal of the Cancer Institute 2002;94(8):558-84.

\section{NICE 2004}

Improving supportive and palliative care for adults with cancer. National Institute of Excellence 2004:9.

\section{Owen 2007}

Owen JE, Goldstein MS, Lee JH, Breen N, Rowland JH. Use of health-related and cancer-specific support groups among adult cancer survivors. Cancer 2007;109:2580-9.

\section{Sellick 1999}

Sellick SM, Crooks DL. Depression and cancer: an appraisal of the literature for prevalence, detection, and practice guideline development for psychological interventions. Psycho-Oncology 1999;8(4):315-33.

\section{Stanton 2006}

Stanton AL. Psychosocial concerns and interventions for cancer survivors. Journal of Clinical Oncology 2006;24(32): 5132-7.

\section{Steginga 2008}

Steginga SK, Campbell A, Ferguson M, Beeden A, Walls M, Cairns W, Dunn, J. Socio-demographic, psychosocial and attitudinal predictors of help seeking after cancer diagnosis. Psycho-Oncology 2008;17:997-1005.

\section{Turton 2000}

Turton P, Cooke H. Meeting the needs of people with cancer for support and self-management. Complementary Therapies in Nursing and Midwifery 2000;6(3):130-7.

\section{Weich 2007}

Weich S, Morgan L, King M, Nazareth I. Attitudes to depression and its treatment in primary care. Psychological Medicine 2007;37:1239-48.

\section{Weis 2003}

Weis J. Support groups for cancer patients. Supportive Cancer Care 2003;11:763-76.

* Indicates the major publication for the study 


\section{CHARACTERISTICS OF STUDIES}

\section{Characteristics of included studies [ordered by study ID]}

\begin{tabular}{|c|c|c|}
\hline Methods & \multicolumn{2}{|l|}{ RCT } \\
\hline Participants & \multicolumn{2}{|l|}{117} \\
\hline Interventions & \multicolumn{2}{|c|}{$\begin{array}{l}\text { The Attentional Focus and Symptom Management Intervention (AFSMI); cognitive } \\
\text { therapy focused on coping }\end{array}$} \\
\hline Outcomes & \multicolumn{2}{|c|}{ Profile of Mood States (POMS), Symptom Impact Profile (SIP) } \\
\hline Notes & \multicolumn{2}{|c|}{ Intervention timed to be carried out post-day surgery } \\
\hline \multicolumn{3}{|l|}{ Risk of bias } \\
\hline Bias & Authors' judgement & Support for judgement \\
\hline $\begin{array}{l}\text { Random sequence generation (selection } \\
\text { bias) }\end{array}$ & Low risk & Random number table \\
\hline Allocation concealment (selection bias) & High risk & Open random allocation schedule \\
\hline Selective reporting (reporting bias) & Unclear risk & $\begin{array}{l}\text { Insufficient information to permit judgement of 'Low risk' or } \\
\text { 'High risk' }\end{array}$ \\
\hline Other bias & Unclear risk & $\begin{array}{l}\text { Author (PhD student and Principle Investigator) designed and } \\
\text { delivered the intervention }\end{array}$ \\
\hline
\end{tabular}

Burton 1995

\begin{tabular}{l|l}
\hline Murton 1995 & RCT \\
\hline Participants & 200 \\
\hline Interventions & $\begin{array}{l}\text { All: Pre-operative interview with a Clinical Psychologist Group 1, 30 minute counselling } \\
\text { session Grp 2, 30 minute chat Grp 3, no counselling or chat }\end{array}$ \\
\hline Outcomes & GHQ-12, HADS, Present State Examination, Coping Scale \\
\hline Notes & Preparation for surgery \\
\hline Risk of bias &
\end{tabular}

Bias

Authors' judgement Support for judgement

Psychosocial interventions to improve quality of life and emotional wellbeing for recently diagnosed cancer patients (Review) 
Burton 1995 (Continued)

\begin{tabular}{l|l|l}
\hline $\begin{array}{l}\text { Random sequence generation (selection } \\
\text { bias) }\end{array}$ & Low risk & Random number table \\
\hline Allocation concealment (selection bias) & High risk & Open random allocation schedule \\
\hline Selective reporting (reporting bias) & Low risk & $\begin{array}{l}\text { The study protocol is not available but it is clear that the pub- } \\
\text { lished reports include all expected outcomes, including those } \\
\text { that were pre-specified }\end{array}$ \\
\hline Other bias & Unclear risk & $\begin{array}{l}\text { Insufficient information to permit judgement of 'Low risk' or } \\
\text { 'High risk' }\end{array}$ \\
\hline
\end{tabular}

Chan 2005

\begin{tabular}{|c|c|c|}
\hline Methods & \multicolumn{2}{|l|}{ RCT } \\
\hline Participants & \multicolumn{2}{|l|}{155} \\
\hline Interventions & \multicolumn{2}{|c|}{ Individual psychological intervention using CBT techniques } \\
\hline Outcomes & \multicolumn{2}{|c|}{ EORTC QLQ-30, BDI, Rosenberg Self-esteem Scale, Impact of Events } \\
\hline \multicolumn{3}{|l|}{ Notes } \\
\hline \multicolumn{3}{|l|}{ Risk of bias } \\
\hline Bias & Authors' judgement & Support for judgement \\
\hline $\begin{array}{l}\text { Random sequence generation (selection } \\
\text { bias) }\end{array}$ & Low risk & Computer random number generator \\
\hline Allocation concealment (selection bias) & Low risk & Opaque, sealed envelopes. \\
\hline Selective reporting (reporting bias) & Unclear risk & $\begin{array}{l}\text { Insufficient information to permit judgement of 'Low risk' or } \\
\text { 'High risk' }\end{array}$ \\
\hline Other bias & Unclear risk & $\begin{array}{l}\text { Insufficient information to permit judgement of 'Low risk' or } \\
\text { 'High risk' }\end{array}$ \\
\hline
\end{tabular}

Dow Meneses 2007

\begin{tabular}{ll}
\hline Methods & RCT \\
\hline Participants & 256
\end{tabular}




\section{Dow Meneses 2007 (Continued)}

\begin{tabular}{|c|c|c|}
\hline Interventions & \multicolumn{2}{|c|}{$\begin{array}{l}\text { Breast Cancer Education Intervention (BCIP); Psychoeducational support for practical, } \\
\text { physical and emotional concerns }\end{array}$} \\
\hline Outcomes & \multicolumn{2}{|c|}{ Quality of Life - Breast Cancer Survivors } \\
\hline \multicolumn{3}{|l|}{ Notes } \\
\hline \multicolumn{3}{|l|}{ Risk of bias } \\
\hline Bias & Authors' judgement & Support for judgement \\
\hline $\begin{array}{l}\text { Random sequence generation (selection } \\
\text { bias) }\end{array}$ & Low risk & Statistician performed randomisation \\
\hline Allocation concealment (selection bias) & Unclear risk & $\begin{array}{l}\text { Insufficient information to permit judgement of 'Low risk' or } \\
\text { 'High risk' }\end{array}$ \\
\hline Selective reporting (reporting bias) & Unclear risk & $\begin{array}{l}\text { Insufficient information to permit judgement of 'Low risk' or } \\
\text { 'High risk' }\end{array}$ \\
\hline Other bias & Unclear risk & $\begin{array}{l}\text { Insufficient information to permit judgement of 'Low risk' or } \\
\text { 'High risk'. Promotion of oncological nursing is strong through- } \\
\text { out }\end{array}$ \\
\hline
\end{tabular}

Downe-Wamboldt 2007

\begin{tabular}{ll}
\hline Methods & RCT \\
\hline Participants & 175 \\
\hline Interventions & Telephone problem solving counselling \\
\hline Outcomes & CES-D, Jalowec Coping Scale, PAIS-SR \\
\hline Notes & \\
\hline
\end{tabular}

\section{Risk of bias}

Bias

Random sequence generation (selection Low risk bias)

\begin{tabular}{lll}
\hline Allocation concealment (selection bias) & Low risk & Concealed random number allocation \\
\hline Selective reporting (reporting bias) & Unclear risk & $\begin{array}{l}\text { Insufficient information to permit judgement of 'Low risk' or } \\
\text { 'High risk' }\end{array}$
\end{tabular}

Psychosocial interventions to improve quality of life and emotional wellbeing for recently diagnosed cancer patients (Review)

Copyright @ 2012 The Cochrane Collaboration. Published by John Wiley \& Sons, Ltd. 
Downe-Wamboldt 2007 (Continued)

$\begin{array}{lll}\text { Other bias } & \text { Unclear risk } & \begin{array}{l}\text { Insufficient information to permit judgement of 'Low risk' or } \\ \text { 'High risk' }\end{array}\end{array}$

\section{Edgar 2001}

\begin{tabular}{|c|c|c|}
\hline Methods & \multicolumn{2}{|l|}{ RCT } \\
\hline Participants & \multicolumn{2}{|l|}{225} \\
\hline Interventions & \multicolumn{2}{|c|}{$\begin{array}{l}\mathrm{CBT} \text {; enhance sense of personal control and learning emotional and instrumental coping } \\
\text { responses }\end{array}$} \\
\hline Outcomes & \multicolumn{2}{|l|}{ FACT, POMS } \\
\hline \multicolumn{3}{|l|}{ Notes } \\
\hline \multicolumn{3}{|l|}{ Risk of bias } \\
\hline Bias & Authors' judgement & Support for judgement \\
\hline $\begin{array}{l}\text { Random sequence generation (selection } \\
\text { bias) }\end{array}$ & Unclear risk & $\begin{array}{l}\text { Insufficient information to permit judgement of 'Low risk' or } \\
\text { 'High risk' }\end{array}$ \\
\hline Allocation concealment (selection bias) & Unclear risk & $\begin{array}{l}\text { Insufficient information to permit judgement of 'Low risk' or } \\
\text { 'High risk' }\end{array}$ \\
\hline Selective reporting (reporting bias) & Unclear risk & $\begin{array}{l}\text { Insufficient information to permit judgement of 'Low risk' or } \\
\text { 'High risk' }\end{array}$ \\
\hline Other bias & Unclear risk & $\begin{array}{l}\text { Insufficient information to permit judgement of 'Low risk' or } \\
\text { 'High risk' }\end{array}$ \\
\hline
\end{tabular}

Fawzy 1995

\begin{tabular}{ll}
\hline Methods & RCT \\
\hline Participants & 61 \\
\hline Interventions & $\begin{array}{l}\text { Comprehensive health seeking and coping paradigm (CHSCP); Education, stress man- } \\
\text { agement, teaching practical emotional coping skills }\end{array}$ \\
\hline Outcomes & POMS, BSI-53, Dealing with ilness inventory \\
\hline Notes & \\
\hline
\end{tabular}

\section{Risk of bias}


Fawzy 1995 (Continued)

\begin{tabular}{l|l|l}
\hline Bias & Authors' judgement & Support for judgement \\
\hline $\begin{array}{l}\text { Random sequence generation (selection } \\
\text { bias) }\end{array}$ & Unclear risk & $\begin{array}{l}\text { Insufficient information to permit judgement of 'Low risk' or } \\
\text { 'High risk' }\end{array}$ \\
\hline Allocation concealment (selection bias) & Unclear risk & $\begin{array}{l}\text { Insufficient information to permit judgement of 'Low risk' or } \\
\text { 'High risk' }\end{array}$ \\
\hline Selective reporting (reporting bias) & Unclear risk & $\begin{array}{l}\text { Insufficient information to permit judgement of 'Low risk' or } \\
\text { 'High risk' }\end{array}$ \\
\hline Other bias & Unclear risk & $\begin{array}{l}\text { Insufficient information to permit judgement of 'Low risk' or } \\
\text { 'High risk' }\end{array}$ \\
\hline
\end{tabular}

Forester 1985

\begin{tabular}{|c|c|c|}
\hline Methods & \multicolumn{2}{|l|}{ RCT } \\
\hline Participants & \multicolumn{2}{|l|}{100} \\
\hline Interventions & \multicolumn{2}{|c|}{ Supportive educational therapy, interpretive, explanatory therapy and catharsis } \\
\hline Outcomes & \multicolumn{2}{|c|}{ Schedule of Affective Disorders and Schizophrenia (SADS) } \\
\hline \multicolumn{3}{|l|}{ Notes } \\
\hline \multicolumn{3}{|l|}{ Risk of bias } \\
\hline Bias & Authors' judgement & Support for judgement \\
\hline $\begin{array}{l}\text { Random sequence generation (selection } \\
\text { bias) }\end{array}$ & Unclear risk & $\begin{array}{l}\text { Insufficient information to permit judgement of 'Low risk' or } \\
\text { 'High risk' }\end{array}$ \\
\hline Allocation concealment (selection bias) & Unclear risk & $\begin{array}{l}\text { Insufficient information to permit judgement of 'Low risk' or } \\
\text { 'High risk'. Assessor was blinded }\end{array}$ \\
\hline Selective reporting (reporting bias) & Low risk & $\begin{array}{l}\text { Insufficient information to permit judgement of 'Low risk' or } \\
\text { 'High risk' }\end{array}$ \\
\hline Other bias & Unclear risk & $\begin{array}{l}\text { Insufficient information to permit judgement of 'Low risk' or } \\
\text { 'High risk' }\end{array}$ \\
\hline
\end{tabular}


Holtedahl 2005

\begin{tabular}{|c|c|c|}
\hline Methods & \multicolumn{2}{|l|}{ RCT } \\
\hline Participants & \multicolumn{2}{|l|}{91} \\
\hline Interventions & \multicolumn{2}{|c|}{$\begin{array}{l}\text { Counselling provided by the general practitioner to "let the patient tell about experiences } \\
\text { as a cancer patient, and to tell the patient explicitly that she or he would be welcome to } \\
\text { contact the GP [with any related questions]" }\end{array}$} \\
\hline Outcomes & \multicolumn{2}{|c|}{ EORTC QLQ-30 and a satisfaction questionnaire } \\
\hline \multicolumn{3}{|l|}{ Notes } \\
\hline \multicolumn{3}{|l|}{ Risk of bias } \\
\hline Bias & Authors' judgement & Support for judgement \\
\hline $\begin{array}{l}\text { Random sequence generation (selection } \\
\text { bias) }\end{array}$ & Low risk & Random number table \\
\hline Allocation concealment (selection bias) & Low risk & Concealed random number allocation \\
\hline Selective reporting (reporting bias) & Unclear risk & $\begin{array}{l}\text { Insufficient information to permit judgement of 'Low risk' or } \\
\text { 'High risk' }\end{array}$ \\
\hline Other bias & Unclear risk & $\begin{array}{l}\text { Insufficient information to permit judgement of 'Low risk' or } \\
\text { 'High risk' }\end{array}$ \\
\hline
\end{tabular}

\section{Jacobsen 2002}

\begin{tabular}{ll}
\hline Methods & RCT \\
\hline Participants & 382 \\
\hline Interventions & Breathing exercises, relaxation exercises, stress innoculation training \\
\hline Outcomes & SF-36, CES-D, STAI-S \\
\hline Notes & \\
\hline
\end{tabular}

\section{Risk of bias}

\section{Bias}

Random sequence generation (selection Low risk bias)

Allocation concealment (selection bias)

\section{Authors' judgement Support for judgement}

Computer random number generator

Open random allocation schedule 
Jacobsen 2002 (Continued)

\begin{tabular}{|c|c|c|}
\hline Selective reporting (reporting bias) & Unclear risk & $\begin{array}{l}\text { Insufficient information to permit judgement of 'Low risk' or } \\
\text { 'High risk' }\end{array}$ \\
\hline Other bias & Unclear risk & $\begin{array}{l}\text { Standard care included a psychological assessment and informa- } \\
\text { tion about available sources of support }\end{array}$ \\
\hline
\end{tabular}

Johansson 2008

\begin{tabular}{|c|c|c|}
\hline Methods & \multicolumn{2}{|l|}{ RCT } \\
\hline Participants & \multicolumn{2}{|l|}{481} \\
\hline Interventions & \multicolumn{2}{|c|}{$\begin{array}{l}\text { Individual psychological support, intensified primary health care (liaison improved and } \\
\text { training for nurses and GPs) and nutritional support (dietary assessment and advice) }\end{array}$} \\
\hline Outcomes & \multicolumn{2}{|c|}{ EORTC QLQ-30, Hospital Anxiety and Depression Scale HADS } \\
\hline Notes & \multicolumn{2}{|c|}{$\begin{array}{l}\text { Nutritional dietary support and liaison with general practice staff (including training for } \\
\text { GPs and nurses) also formed part of the intervention }\end{array}$} \\
\hline \multicolumn{3}{|l|}{ Risk of bias } \\
\hline Bias & Authors' judgement & Support for judgement \\
\hline $\begin{array}{l}\text { Random sequence generation (selection } \\
\text { bias) }\end{array}$ & Low risk & Computer generated random allocation \\
\hline Allocation concealment (selection bias) & Unclear risk & $\begin{array}{l}\text { Insufficient information to permit judgement of 'Low risk' or } \\
\text { 'High risk' }\end{array}$ \\
\hline Selective reporting (reporting bias) & Unclear risk & $\begin{array}{l}\text { Insufficient information to permit judgement of 'Low risk' or } \\
\text { 'High risk' }\end{array}$ \\
\hline Other bias & Unclear risk & $\begin{array}{l}\text { Insufficient information to permit judgement of 'Low risk' or } \\
\text { 'High risk' }\end{array}$ \\
\hline
\end{tabular}

Kanzaki 2002

\begin{tabular}{ll}
\hline Methods & RCT \\
\hline Participants & 26 \\
\hline Interventions & $\begin{array}{l}\text { Counselling and journal writing based on stress coping theory (Lazarus) and Social } \\
\text { Learning theory (Bandura) }\end{array}$ \\
\hline Outcomes & Depression and Anxiety Mood Scale, General Self Efficacy Scale, Stress Response Scale
\end{tabular}

Psychosocial interventions to improve quality of life and emotional wellbeing for recently diagnosed cancer patients (Review) 
Kanzaki 2002 (Continued)

\begin{tabular}{lll} 
Notes & \\
\hline Risk of bias & Authors' judgement & Support for judgement \\
\hline Bias & Insufficient information to permit judgement of 'Low risk' or \\
\hline $\begin{array}{l}\text { Random sequence generation (selection } \\
\text { bias) }\end{array}$ & High risk & 'High risk' \\
\hline Allocation concealment (selection bias) & Low risk & Concealed from staff \\
\hline Selective reporting (reporting bias) & Unclear risk & $\begin{array}{l}\text { Insufficient information to permit judgement of 'Low risk' or } \\
\text { 'High risk' }\end{array}$ \\
\hline Other bias & Unclear risk & $\begin{array}{l}\text { Insufficient information to permit judgement of 'Low risk' or } \\
\text { 'High risk' }\end{array}$ \\
\hline
\end{tabular}

Lee 2006

\begin{tabular}{|c|c|c|}
\hline Methods & \multicolumn{2}{|l|}{ RCT } \\
\hline Participants & \multicolumn{2}{|l|}{82} \\
\hline Interventions & \multicolumn{2}{|c|}{$\begin{array}{l}\text { Meaning-making intervention to acknowledge the present, contemplate the past, commit } \\
\text { to the present, for the future }\end{array}$} \\
\hline Outcomes & \multicolumn{2}{|c|}{$\begin{array}{l}\text { Rosenberg Self-esteem Scale, Life Orientation Test (optimism), Generalised Self Efficacy } \\
\text { Scale }\end{array}$} \\
\hline \multicolumn{3}{|l|}{ Notes } \\
\hline \multicolumn{3}{|l|}{ Risk of bias } \\
\hline Bias & Authors' judgement & Support for judgement \\
\hline $\begin{array}{l}\text { Random sequence generation (selection } \\
\text { bias) }\end{array}$ & Low risk & Computer generated random allocation \\
\hline Allocation concealment (selection bias) & High risk & Open random allocation schedule \\
\hline Selective reporting (reporting bias) & Unclear risk & $\begin{array}{l}\text { Insufficient information to permit judgement of 'Low risk' or } \\
\text { 'High risk' }\end{array}$ \\
\hline Other bias & High risk & $11 \%$ of participants already receiving psychosocial support \\
\hline
\end{tabular}




\begin{tabular}{|c|c|c|}
\hline Methods & \multicolumn{2}{|l|}{ RCT } \\
\hline Participants & \multicolumn{2}{|l|}{18} \\
\hline Interventions & \multicolumn{2}{|c|}{$\begin{array}{l}\text { Combination of information provided by videotape and booklet, along with } 5 \text { coun- } \\
\text { selling sessions based on Bandura principles of practicing behaviours to increase self- } \\
\text { efficacy }\end{array}$} \\
\hline Outcomes & \multicolumn{2}{|c|}{$\begin{array}{l}\text { FACT, Symptom Distess Scale (SDS), Strategies used by patients to promote health } \\
\text { (SUPPH) }\end{array}$} \\
\hline \multicolumn{3}{|l|}{ Notes } \\
\hline \multicolumn{3}{|l|}{ Risk of bias } \\
\hline Bias & Authors' judgement & Support for judgement \\
\hline $\begin{array}{l}\text { Random sequence generation (selection } \\
\text { bias) }\end{array}$ & Unclear risk & $\begin{array}{l}\text { Insufficient information to permit judgement of 'Low risk' or } \\
\text { 'High risk' }\end{array}$ \\
\hline Allocation concealment (selection bias) & Unclear risk & $\begin{array}{l}\text { Insufficient information to permit judgement of 'Low risk' or } \\
\text { 'High risk' }\end{array}$ \\
\hline Selective reporting (reporting bias) & Unclear risk & $\begin{array}{l}\text { Insufficient information to permit judgement of 'Low risk' or } \\
\text { 'High risk' }\end{array}$ \\
\hline Other bias & High risk & $\begin{array}{l}\text { Selected effect sizes provided in text, but no tables of figures } \\
\text { presented }\end{array}$ \\
\hline
\end{tabular}

Linn 1981

\begin{tabular}{l|l}
\hline Methods & RCT \\
\hline Participants & 120 \\
\hline Interventions & Therapeutic relationship developed, based on trust and open communication \\
\hline Outcomes & $\begin{array}{l}\text { Quality of life described by depression, self-esteem, alienation, life satisfaction, locus of } \\
\text { control }\end{array}$ \\
\hline Notes & $\begin{array}{l}\text { All participants classified as diagnosed within 6-10 months, with prognosis of being } \\
\text { terminally ill }\end{array}$ \\
\hline
\end{tabular}

\section{Risk of bias}

Bias

Authors' judgement Support for judgement 


\section{Linn 1981 (Continued)}

\begin{tabular}{l|l|l}
\hline $\begin{array}{l}\text { Random sequence generation (selection } \\
\text { bias) }\end{array}$ & Unclear risk & $\begin{array}{l}\text { Insufficient information to permit judgement of 'Low risk' or } \\
\text { 'High risk' }\end{array}$ \\
\hline Allocation concealment (selection bias) & Unclear risk & $\begin{array}{l}\text { Insufficient information to permit judgement of 'Low risk' or } \\
\text { 'High risk' }\end{array}$ \\
\hline Selective reporting (reporting bias) & High risk & Only descriptive data is provided \\
\hline Other bias & Unclear risk & $\begin{array}{l}\text { Insufficient information to permit judgement of 'Low risk' or } \\
\text { 'High risk' }\end{array}$ \\
\hline
\end{tabular}

Manne 2007

\begin{tabular}{|c|c|c|}
\hline Methods & \multicolumn{2}{|l|}{ RCT } \\
\hline Participants & \multicolumn{2}{|l|}{353} \\
\hline Interventions & \multicolumn{2}{|c|}{$\begin{array}{l}\text { Two types of intervention: (1) counselling for coping and communication, (2) supportive } \\
\text { psychotherapy }\end{array}$} \\
\hline Outcomes & \multicolumn{2}{|c|}{$\begin{array}{l}\text { BDI, IES (Intrusive and Advoidant Ideation), Emotional Expressiveness Questionnaire, } \\
\text { Treatment expectancy, treatment evaluation }\end{array}$} \\
\hline Notes & \multicolumn{2}{|c|}{$\begin{array}{l}\text { Query diagnosis within } 12 \text { months - described by authors as a weakness/limitation of } \\
\text { the study, due to lack of information about time since diagnosis }\end{array}$} \\
\hline \multicolumn{3}{|l|}{ Risk of bias } \\
\hline Bias & Authors' judgement & Support for judgement \\
\hline $\begin{array}{l}\text { Random sequence generation (selection } \\
\text { bias) }\end{array}$ & Unclear risk & $\begin{array}{l}\text { Insufficient information to permit judgement of 'Low risk' or } \\
\text { 'High risk' }\end{array}$ \\
\hline Allocation concealment (selection bias) & High risk & Open random allocation schedule \\
\hline Selective reporting (reporting bias) & Unclear risk & $\begin{array}{l}\text { Insufficient information to permit judgement of 'Low risk' or } \\
\text { 'High risk' }\end{array}$ \\
\hline Other bias & High risk & $\begin{array}{l}\text { Usual care included assessment by a social worker and subse- } \\
\text { quent referral to supportive services if indicated }\end{array}$ \\
\hline
\end{tabular}


McArdle 1996

\begin{tabular}{|c|c|c|}
\hline Methods & \multicolumn{2}{|l|}{ RCT } \\
\hline Participants & \multicolumn{2}{|l|}{272} \\
\hline Interventions & \multicolumn{2}{|c|}{$\begin{array}{l}\text { Group } 1 \text {, Nurse provided pre and post-operative information and a listening ear. Group } \\
2 \text {, as group } 1 \text { with counselling from a voluntary sector organisation also offered (with } \\
\text { membership of a support group also offered as an option) }\end{array}$} \\
\hline Outcomes & \multicolumn{2}{|l|}{ GHQ-28, HADS } \\
\hline Notes & \multicolumn{2}{|c|}{$\begin{array}{l}9 \% \text { experiencing recurrence, remaining participants were newly diagnosed (within } 12 \\
\text { months), Group1, nursing intervention included the option of having a partner present } \\
\text { - results not disaggregated }\end{array}$} \\
\hline \multicolumn{3}{|l|}{ Risk of bias } \\
\hline Bias & Authors' judgement & Support for judgement \\
\hline $\begin{array}{l}\text { Random sequence generation (selection } \\
\text { bias) }\end{array}$ & Unclear risk & $\begin{array}{l}\text { Insufficient information to permit judgement of 'Low risk' or } \\
\text { 'High risk' }\end{array}$ \\
\hline Allocation concealment (selection bias) & Unclear risk & $\begin{array}{l}\text { Insufficient information to permit judgement of 'Low risk' or } \\
\text { 'High risk' }\end{array}$ \\
\hline Selective reporting (reporting bias) & Unclear risk & $\begin{array}{l}\text { Insufficient information to permit judgement of 'Low risk' or } \\
\text { 'High risk' }\end{array}$ \\
\hline Other bias & Unclear risk & $\begin{array}{l}\text { Insufficient information to permit judgement of 'Low risk' or } \\
\text { 'High risk' }\end{array}$ \\
\hline
\end{tabular}

McQuellon 1998

\begin{tabular}{ll}
\hline Methods & RCT \\
\hline Participants & 150 \\
\hline Interventions & $\begin{array}{l}\text { Single session orientation programme including time with an oncology counsellor to } \\
\text { express concerns }\end{array}$ \\
\hline Outcomes & STAI, POMS, CES-D \\
\hline Notes & \\
\hline Risk of bias &
\end{tabular}

Bias

Authors' judgement Support for judgement

Psychosocial interventions to improve quality of life and emotional wellbeing for recently diagnosed cancer patients (Review) 
McQuellon 1998 (Continued)

\begin{tabular}{l|l|l}
\hline $\begin{array}{l}\text { Random sequence generation (selection } \\
\text { bias) }\end{array}$ & Unclear risk & $\begin{array}{l}\text { Insufficient information to permit judgement of 'Low risk' or } \\
\text { 'High risk' }\end{array}$ \\
\hline Allocation concealment (selection bias) & Unclear risk & $\begin{array}{l}\text { Insufficient information to permit judgement of 'Low risk' or } \\
\text { 'High risk' }\end{array}$ \\
\hline Selective reporting (reporting bias) & Unclear risk & $\begin{array}{l}\text { Insufficient information to permit judgement of 'Low risk' or } \\
\text { 'High risk' }\end{array}$ \\
\hline Other bias & Unclear risk & $\begin{array}{l}\text { Insufficient information to permit judgement of 'Low risk' or } \\
\text { 'High risk' }\end{array}$ \\
\hline
\end{tabular}

\section{Mishel 2002}

\begin{tabular}{|c|c|c|}
\hline Methods & \multicolumn{2}{|l|}{ RCT } \\
\hline Participants & \multicolumn{2}{|l|}{239} \\
\hline Interventions & \multicolumn{2}{|c|}{ Patient-led telephone CBT intervention with supplemental audio/video tapes provided } \\
\hline Outcomes & \multicolumn{2}{|c|}{$\begin{array}{l}\text { MMSE, Uncertainty in illness scale, Cancer knowledge scale, (subscales reported; symp- } \\
\text { tom distress or QOL and problem solving and cognitive restructuring as self-control } \\
\text { scale) }\end{array}$} \\
\hline Notes & \multicolumn{2}{|c|}{$\begin{array}{l}\text { Number of participants in each arm not reported (one arm included family member) } \\
\text { also } 0.1 \text { significance level used }\end{array}$} \\
\hline \multicolumn{3}{|l|}{ Risk of bias } \\
\hline Bias & Authors' judgement & Support for judgement \\
\hline $\begin{array}{l}\text { Random sequence generation (selection } \\
\text { bias) }\end{array}$ & Unclear risk & Block randomisation (randomisation process not described) \\
\hline Allocation concealment (selection bias) & High risk & Open random allocation schedule \\
\hline Selective reporting (reporting bias) & Unclear risk & $\begin{array}{l}\text { Insufficient information to permit judgement of 'Low risk' or } \\
\text { 'High risk' }\end{array}$ \\
\hline Other bias & Unclear risk & $\begin{array}{l}\text { Insufficient information to permit judgement of 'Low risk' or } \\
\text { 'High risk' }\end{array}$ \\
\hline
\end{tabular}


Moynihan 1998

\begin{tabular}{l|l}
\hline Methods & RCT \\
\hline Participants & 73 \\
\hline Interventions & $\begin{array}{l}\text { Adjuvant psychological therapy; a cognitive and behavioural treatment programme de- } \\
\text { signed specifically for patients with cancer }\end{array}$ \\
\hline Outcomes & $\begin{array}{l}\text { HADS, Mental adjustment to cancer scale, Psychosocial adjustment to illness scale, Emo- } \\
\text { tional concealment sunscale of the brannon masculinity scale, Reiker sexual adjustment } \\
\text { scale }\end{array}$ \\
\hline Notes & \\
\hline
\end{tabular}

\section{Risk of bias}

\begin{tabular}{l|l|l} 
Bias & Authors' judgement & Support for judgement \\
\hline $\begin{array}{l}\text { Random sequence generation (selection } \\
\text { bias) }\end{array}$ & Low risk & Carried out by an independent trials office \\
\hline Allocation concealment (selection bias) & Low risk & Concealed random number allocation \\
\hline Selective reporting (reporting bias) & Unclear risk & $\begin{array}{l}\text { Insufficient information to permit judgement of 'Low risk' or } \\
\text { 'High risk' }\end{array}$ \\
\hline Other bias & Unclear risk & $\begin{array}{l}\text { Insufficient information to permit judgement of 'Low risk' or } \\
\text { 'High risk' }\end{array}$ \\
\hline
\end{tabular}

Nezu 2003

\begin{tabular}{l|l}
\hline Methods & RCT \\
\hline Participants & 150 \\
\hline Interventions & $\begin{array}{l}\text { Problem Solving Therapy (PST) teaching to better formulate problems, generate alter- } \\
\text { native solutions, evaluate consequences, select and evaluate outcome }\end{array}$ \\
\hline Outcomes & $\begin{array}{l}\text { POMS, Cancer Rehabilitation Evaluation System (CARES), BSI 53-item psychiatric } \\
\text { symptoms, Omega Vulnerability Rating Scales, HRSD }\end{array}$ \\
\hline Notes & \\
\hline
\end{tabular}

\section{Risk of bias}

\begin{tabular}{l|l|l}
\hline Bias & Authors' judgement & Support for judgement \\
\hline $\begin{array}{l}\text { Random sequence generation } \\
\text { bias) }\end{array}$ & Random numbers table \\
\hline $\begin{array}{l}\text { Psychosocial interventions to improve quality of life and emotional wellbeing for recently diagnosed cancer patients (Review) } \\
\text { Copyright } \odot 2012 \text { The Cochrane Collaboration. Published by John Wiley \& Sons, Ltd. }\end{array}$ & Low risk
\end{tabular}

Copyright $\odot 2012$ The Cochrane Collaboration. Published by John Wiley \& Sons, Ltd. 


\section{Nezu 2003 (Continued)}

\begin{tabular}{l|l|l}
\hline Allocation concealment (selection bias) & Low risk & Concealed random number allocation \\
\hline Selective reporting (reporting bias) & Unclear risk & $\begin{array}{l}\text { Insufficient information to permit judgement of 'Low risk' or } \\
\text { 'High risk' }\end{array}$ \\
\hline Other bias & Unclear risk & $\begin{array}{l}\text { Insufficient information to permit judgement of 'Low risk' or } \\
\text { 'High risk' }\end{array}$ \\
\hline
\end{tabular}

Parker 2009

\begin{tabular}{l|l}
\hline Methods & RCT \\
\hline Participants & 159 \\
\hline Interventions & $\begin{array}{l}60-90 \text { minute stress management cognitive behavioural sessions including diaphragmatic } \\
\text { breathing and guided imagery }\end{array}$ \\
\hline Outcomes & SF-36 \\
\hline Notes & $\begin{array}{l}\text { Correspondence with author confirmed only two participants had been diagnosed more } \\
\text { than } 12 \text { months prior to the intervention }\end{array}$ \\
\hline
\end{tabular}

\section{Risk of bias}

\begin{tabular}{l|l|l}
\hline Bias & Authors' judgement & Support for judgement \\
\hline $\begin{array}{l}\text { Random sequence generation (selection } \\
\text { bias) }\end{array}$ & Unclear risk & $\begin{array}{l}\text { Insufficient information to permit judgement of 'Low risk' or } \\
\text { 'High risk' }\end{array}$ \\
\hline Allocation concealment (selection bias) & Unclear risk & $\begin{array}{l}\text { Insufficient information to permit judgement of 'Low risk' or } \\
\text { 'High risk' }\end{array}$ \\
\hline Selective reporting (reporting bias) & Unclear risk & $\begin{array}{l}\text { Insufficient information to permit judgement of 'Low risk' or } \\
\text { 'High risk' }\end{array}$ \\
\hline Other bias & Unclear risk & $\begin{array}{l}\text { Insufficient information to permit judgement of 'Low risk' or } \\
\text { 'High risk' }\end{array}$ \\
\hline
\end{tabular}

Petersen 2002

\begin{tabular}{l|l}
\hline Methods & RCT \\
\hline Participants & 53 \\
\hline Interventions & $\begin{array}{l}\text { "Counselling interview"; relaxation music (5min) relaxation exercise (20min) and dis- } \\
\text { cussion on patient emotional and physical condition }\end{array}$
\end{tabular}


Petersen 2002 (Continued)

\begin{tabular}{|c|c|c|}
\hline Outcomes & \multicolumn{2}{|l|}{ GHQ-28, HADS } \\
\hline \multicolumn{3}{|l|}{ Notes } \\
\hline \multicolumn{3}{|l|}{ Risk of bias } \\
\hline Bias & Authors' judgement & Support for judgement \\
\hline $\begin{array}{l}\text { Random sequence generation (selection } \\
\text { bias) }\end{array}$ & Unclear risk & $\begin{array}{l}\text { Insufficient information to permit judgement of 'Low risk' or } \\
\text { 'High risk' }\end{array}$ \\
\hline Allocation concealment (selection bias) & Low risk & Concealed random number allocation \\
\hline Selective reporting (reporting bias) & Unclear risk & $\begin{array}{l}\text { Insufficient information to permit judgement of 'Low risk' or } \\
\text { 'High risk' }\end{array}$ \\
\hline Other bias & Unclear risk & $\begin{array}{l}\text { Insufficient information to permit judgement of 'Low risk' or } \\
\text { 'High risk' }\end{array}$ \\
\hline
\end{tabular}

Pitcheathly 2008

\begin{tabular}{l|l}
\hline Methods & RCT \\
\hline Participants & 465 \\
\hline Interventions & $\begin{array}{l}\text { Three-session brief intervention, delivered by trained non-specialists, focused on coping } \\
\text { strategies }\end{array}$ \\
\hline Outcomes & DSM Structured clinical interview, Hospital Anxiety and Depression Scale (HADS) \\
\hline Notes & $\begin{array}{l}\text { Designed to prevent depression and anxiety, rather than to improve quality of life, per } \\
\text { se }\end{array}$ \\
\hline
\end{tabular}

\section{Risk of bias}

\begin{tabular}{l|l|l}
\hline Bias & Authors' judgement & Support for judgement \\
\hline $\begin{array}{l}\text { Random sequence generation (selection } \\
\text { bias) }\end{array}$ & Unclear risk & $\begin{array}{l}\text { Insufficient information to permit judgement of 'Low risk' or } \\
\text { 'High risk' }\end{array}$ \\
\hline Allocation concealment (selection bias) & Unclear risk & $\begin{array}{l}\text { Insufficient information to permit judgement of 'Low risk' or } \\
\text { 'High risk' }\end{array}$ \\
\hline Selective reporting (reporting bias) & Unclear risk & $\begin{array}{l}\text { Insufficient information to permit judgement of 'Low risk' or } \\
\text { 'High risk' }\end{array}$ \\
\hline
\end{tabular}


Pitcheathly 2008 (Continued)

\begin{tabular}{|c|c|c|}
\hline Other bias & Unclear risk & $\begin{array}{l}\text { Insufficient information to permit judgement of 'Low risk' or } \\
\text { 'High risk' }\end{array}$ \\
\hline
\end{tabular}

Puig 2006

\begin{tabular}{|c|c|c|}
\hline Methods & \multicolumn{2}{|l|}{ RCT } \\
\hline Participants & \multicolumn{2}{|l|}{39} \\
\hline Interventions & \multicolumn{2}{|c|}{$\begin{array}{l}\text { Creative arts therapy - psychoeducational and subjective understanding of body-mind- } \\
\text { emotions and spiritual experiences and connections }\end{array}$} \\
\hline Outcomes & \multicolumn{2}{|c|}{$\begin{array}{l}\text { Satisfaction with intervention, Expressions of spirituality inventory, Emotional approach } \\
\text { coping scale }\end{array}$} \\
\hline \multicolumn{3}{|l|}{ Notes } \\
\hline \multicolumn{3}{|l|}{ Risk of bias } \\
\hline Bias & Authors' judgement & Support for judgement \\
\hline $\begin{array}{l}\text { Random sequence generation (selection } \\
\text { bias) }\end{array}$ & Unclear risk & $\begin{array}{l}\text { Insufficient information to permit judgement of 'Low risk' or } \\
\text { 'High risk' }\end{array}$ \\
\hline Allocation concealment (selection bias) & Unclear risk & $\begin{array}{l}\text { Insufficient information to permit judgement of 'Low risk' or } \\
\text { 'High risk' }\end{array}$ \\
\hline Selective reporting (reporting bias) & Unclear risk & $\begin{array}{l}\text { Insufficient information to permit judgement of 'Low risk' or } \\
\text { 'High risk' }\end{array}$ \\
\hline Other bias & Unclear risk & $\begin{array}{l}\text { Insufficient information to permit judgement of 'Low risk' or } \\
\text { 'High risk' }\end{array}$ \\
\hline
\end{tabular}

Ross 2005

\begin{tabular}{ll}
\hline Methods & RCT \\
\hline Participants & 249 \\
\hline Interventions & $\begin{array}{l}\text { Home visit, average } 1 \text { hour, emotional and educational support, encouraging use of } \\
\text { participant's social networks for support }\end{array}$ \\
\hline Outcomes & EORTC QLQ-30, EORTC CR38, HADS \\
\hline
\end{tabular}

Notes

Psychosocial interventions to improve quality of life and emotional wellbeing for recently diagnosed cancer patients (Review) 
Ross 2005 (Continued)

\begin{tabular}{|c|c|c|}
\hline Bias & Authors' judgement & Support for judgement \\
\hline $\begin{array}{l}\text { Random sequence generation (selection } \\
\text { bias) }\end{array}$ & Low risk & Computer generated block randomisation \\
\hline Allocation concealment (selection bias) & Low risk & Concealed random number allocation \\
\hline Selective reporting (reporting bias) & Unclear risk & $\begin{array}{l}\text { Insufficient information to permit judgement of 'Low risk' or } \\
\text { 'High risk' }\end{array}$ \\
\hline Other bias & Unclear risk & $\begin{array}{l}\text { Insufficient information to permit judgement of 'Low risk' or } \\
\text { 'High risk' }\end{array}$ \\
\hline
\end{tabular}

\section{Sandgren 2000}

\begin{tabular}{|c|c|c|}
\hline Methods & \multicolumn{2}{|l|}{$\mathrm{RCT}$} \\
\hline Participants & \multicolumn{2}{|l|}{53} \\
\hline Interventions & \multicolumn{2}{|c|}{$\begin{array}{l}\text { Patient generated problems, cognitive restructuring, coping skills, managing anxiety and } \\
\text { stress, emotional expression, relaxation }\end{array}$} \\
\hline Outcomes & \multicolumn{2}{|c|}{ POMS, Medical Outcomes Scale, Coping Response Indices-Revised } \\
\hline \multicolumn{3}{|l|}{ Notes } \\
\hline \multicolumn{3}{|l|}{ Risk of bias } \\
\hline Bias & Authors' judgement & Support for judgement \\
\hline $\begin{array}{l}\text { Random sequence generation (selection } \\
\text { bias) }\end{array}$ & Unclear risk & $\begin{array}{l}\text { Insufficient information to permit judgement of 'Low risk' or } \\
\text { 'High risk' }\end{array}$ \\
\hline Allocation concealment (selection bias) & Unclear risk & $\begin{array}{l}\text { Insufficient information to permit judgement of 'Low risk' or } \\
\text { 'High risk' }\end{array}$ \\
\hline Selective reporting (reporting bias) & Unclear risk & $\begin{array}{l}\text { Insufficient information to permit judgement of 'Low risk' or } \\
\text { 'High risk' }\end{array}$ \\
\hline Other bias & Unclear risk & $\begin{array}{l}\text { Insufficient information to permit judgement of 'Low risk' or } \\
\text { 'High risk' }\end{array}$ \\
\hline
\end{tabular}


Sandgren 2003

\begin{tabular}{|c|c|c|}
\hline Methods & \multicolumn{2}{|l|}{ RCT } \\
\hline Participants & \multicolumn{2}{|l|}{222} \\
\hline Interventions & \multicolumn{2}{|c|}{$\begin{array}{l}\text { Emotional Expression - Particpants encouraged to express deepest emotions and thoughts } \\
\text { about cancer experience, facilitator listened and provided 'support' }\end{array}$} \\
\hline Outcomes & \multicolumn{2}{|c|}{$\begin{array}{l}\text { FACT-B, POMS, Perceived Stress Scale, Cancer Behaviour Inventory, Social Constraints } \\
\text { measure }\end{array}$} \\
\hline \multicolumn{3}{|l|}{ Notes } \\
\hline \multicolumn{3}{|l|}{ Risk of bias } \\
\hline Bias & Authors' judgement & Support for judgement \\
\hline $\begin{array}{l}\text { Random sequence generation (selection } \\
\text { bias) }\end{array}$ & Unclear risk & $\begin{array}{l}\text { Insufficient information to permit judgement of 'Low risk' or } \\
\text { 'High risk' }\end{array}$ \\
\hline Allocation concealment (selection bias) & Unclear risk & $\begin{array}{l}\text { Insufficient information to permit judgement of 'Low risk' or } \\
\text { 'High risk' }\end{array}$ \\
\hline Selective reporting (reporting bias) & Unclear risk & $\begin{array}{l}\text { Insufficient information to permit judgement of 'Low risk' or } \\
\text { 'High risk' }\end{array}$ \\
\hline Other bias & Unclear risk & $\begin{array}{l}\text { Insufficient information to permit judgement of 'Low risk' or } \\
\text { 'High risk' }\end{array}$ \\
\hline
\end{tabular}

Sandgren 2007

\begin{tabular}{ll}
\hline Methods & RCT \\
\hline Participants & 218 \\
\hline Interventions & $\begin{array}{l}\text { Emotional Expression - Particpants encouraged to express deepest emotions and thoughts } \\
\text { about cancer experience, facilitator listened and provided 'support' }\end{array}$ \\
\hline Outcomes & $\begin{array}{l}\text { FACT-B, POMS, Perceived Stress Scale, Cancer Behaviour Inventory, Social Constraints } \\
\text { measure }\end{array}$ \\
\hline Notes & \\
\hline
\end{tabular}

\section{Risk of bias}

Bias

Random sequence generation (selection Unclear risk bias)

\section{Authors' judgement Support for judgement}

Insufficient information to permit judgement of 'Low risk' or 'High risk' 


\section{Sandgren 2007 (Continued)}

\begin{tabular}{l|l|l}
\hline Allocation concealment (selection bias) & Unclear risk & $\begin{array}{l}\text { Insufficient information to permit judgement of 'Low risk' or } \\
\text { 'High risk' }\end{array}$ \\
\hline Selective reporting (reporting bias) & Unclear risk & $\begin{array}{l}\text { Insufficient information to permit judgement of 'Low risk' or } \\
\text { 'High risk' }\end{array}$ \\
\hline Other bias & Unclear risk & $\begin{array}{l}\text { Insufficient information to permit judgement of 'Low risk' or } \\
\text { 'High risk' }\end{array}$ \\
\hline
\end{tabular}

Scholten 2001

\begin{tabular}{|c|c|c|}
\hline Methods & \multicolumn{2}{|l|}{ RCT } \\
\hline Participants & \multicolumn{2}{|l|}{84} \\
\hline Interventions & \multicolumn{2}{|c|}{$\begin{array}{l}\text { Crisis intervention tailored individually, by choice out of } 20 \text { intervention areas, modelled } \\
\text { on CBT principles }\end{array}$} \\
\hline Outcomes & \multicolumn{2}{|c|}{$\begin{array}{l}\text { Quality of life (visual analogue scale), health status (visual analogue scale), semi-struc- } \\
\text { tured interview on coping }\end{array}$} \\
\hline Notes & \multicolumn{2}{|c|}{$\begin{array}{l}\text { Study included a second intervention group of participants experiencing recurrence and } \\
\text { control group were half newly diagnosed and half experiencing recurrence }\end{array}$} \\
\hline \multicolumn{3}{|l|}{ Risk of bias } \\
\hline Bias & Authors' judgement & Support for judgement \\
\hline $\begin{array}{l}\text { Random sequence generation (selection } \\
\text { bias) }\end{array}$ & Unclear risk & $\begin{array}{l}\text { Insufficient information to permit judgement of 'Low risk' or } \\
\text { 'High risk' }\end{array}$ \\
\hline Allocation concealment (selection bias) & Unclear risk & $\begin{array}{l}\text { Insufficient information to permit judgement of 'Low risk' or } \\
\text { 'High risk' }\end{array}$ \\
\hline Selective reporting (reporting bias) & Unclear risk & $\begin{array}{l}\text { Insufficient information to permit judgement of 'Low risk' or } \\
\text { 'High risk' }\end{array}$ \\
\hline Other bias & Unclear risk & $\begin{array}{l}\text { Insufficient information to permit judgement of 'Low risk' or } \\
\text { 'High risk' }\end{array}$ \\
\hline
\end{tabular}


Scura 2004

\begin{tabular}{|c|c|c|}
\hline Methods & \multicolumn{2}{|l|}{ RCT } \\
\hline Participants & \multicolumn{2}{|l|}{17} \\
\hline Interventions & \multicolumn{2}{|c|}{$\begin{array}{l}\text { Telephone social support and educational resource kit based on Roy Adaptation Model } \\
\text { of Nursing - biopsychosocial model }\end{array}$} \\
\hline Outcomes & \multicolumn{2}{|c|}{$\begin{array}{l}\text { Fact-G, Symptom Experience Scale-Prostate, Relationship Change Scale, International } \\
\text { Index of Erectile Function Scale }\end{array}$} \\
\hline \multicolumn{3}{|l|}{ Notes } \\
\hline \multicolumn{3}{|l|}{ Risk of bias } \\
\hline Bias & Authors' judgement & Support for judgement \\
\hline $\begin{array}{l}\text { Random sequence generation (selection } \\
\text { bias) }\end{array}$ & Unclear risk & $\begin{array}{l}\text { Insufficient information to permit judgement of 'Low risk' or } \\
\text { 'High risk' }\end{array}$ \\
\hline Allocation concealment (selection bias) & Unclear risk & $\begin{array}{l}\text { Insufficient information to permit judgement of 'Low risk' or } \\
\text { 'High risk' }\end{array}$ \\
\hline Selective reporting (reporting bias) & Unclear risk & $\begin{array}{l}\text { Insufficient information to permit judgement of 'Low risk' or } \\
\text { 'High risk' }\end{array}$ \\
\hline Other bias & Unclear risk & $\begin{array}{l}\text { Insufficient information to permit judgement of 'Low risk' or } \\
\text { 'High risk' }\end{array}$ \\
\hline
\end{tabular}

Stanton 2005

\begin{tabular}{l|l}
\hline Methods & RCT \\
\hline Participants & 558 \\
\hline Interventions & $\begin{array}{l}\text { An } 80 \text {-min face-to-face meeting and video tape with manual provided, followed with a } \\
\text { 30-min telephone meeting }\end{array}$ \\
\hline Outcomes & $\begin{array}{l}\text { SF-36 (Vitality Scale), CES-D, Revised Impact of Events Scale, Post-traumatic Growth } \\
\text { Scale }\end{array}$ \\
\hline Notes & \\
\hline
\end{tabular}

\section{Risk of bias}

\begin{tabular}{l|l|l} 
Bias & Authors' judgement & Support for judgement \\
\hline $\begin{array}{l}\text { Random sequence generation (selection } \\
\text { bias) }\end{array}$ & Low risk & Random number tables \\
\hline
\end{tabular}


Stanton 2005 (Continued)

\begin{tabular}{l|l|l}
\hline Allocation concealment (selection bias) & Low risk & Concealed random number allocation \\
\hline Selective reporting (reporting bias) & Unclear risk & $\begin{array}{l}\text { Insufficient information to permit judgement of 'Low risk' or } \\
\text { 'High risk' }\end{array}$ \\
\hline Other bias & Unclear risk & $\begin{array}{l}\text { Insufficient information to permit judgement of 'Low risk' or } \\
\text { 'High risk' }\end{array}$ \\
\hline
\end{tabular}

Trask 2003

\begin{tabular}{|c|c|c|}
\hline Methods & \multicolumn{2}{|l|}{ RCT } \\
\hline Participants & \multicolumn{2}{|l|}{48} \\
\hline Interventions & \multicolumn{2}{|c|}{ Relaxation training, cognitive challenging and problem solving } \\
\hline Outcomes & \multicolumn{2}{|c|}{ SF-36, STAI, BSI, Global severity index } \\
\hline Notes & \multicolumn{2}{|c|}{ Part of a larger RCT study } \\
\hline \multicolumn{3}{|l|}{ Risk of bias } \\
\hline Bias & Authors' judgement & Support for judgement \\
\hline $\begin{array}{l}\text { Random sequence generation (selection } \\
\text { bias) }\end{array}$ & Low risk & Random number tables \\
\hline Allocation concealment (selection bias) & Low risk & Concealed random number allocation \\
\hline Selective reporting (reporting bias) & Unclear risk & $\begin{array}{l}\text { Insufficient information to permit judgement of 'Low risk' or } \\
\text { 'High risk' }\end{array}$ \\
\hline Other bias & Unclear risk & $\begin{array}{l}\text { Insufficient information to permit judgement of 'Low risk' or } \\
\text { 'High risk' }\end{array}$ \\
\hline
\end{tabular}


DATA AND ANALYSES

Comparison 1. Primary outcome: quality of life

\begin{tabular}{|c|c|c|c|c|}
\hline Outcome or subgroup title & $\begin{array}{l}\text { No. of } \\
\text { studies }\end{array}$ & $\begin{array}{c}\text { No. of } \\
\text { participants }\end{array}$ & Statistical method & Effect size \\
\hline 1 All Studies & 9 & 1249 & Std. Mean Difference (IV, Random, 95\% CI) & $0.11[-0.00,0.22]$ \\
\hline 2 Measures of Quality of Life & 9 & 1249 & Std. Mean Difference (IV, Random, 95\% CI) & $0.11[-0.00,0.22]$ \\
\hline 2.1 General Health Related & 3 & 418 & Std. Mean Difference (IV, Random, 95\% CI) & $0.02[-0.18,0.21]$ \\
\hline \multicolumn{5}{|l|}{ Measures } \\
\hline 2.2 Illness Specific Measures & 6 & 831 & Std. Mean Difference (IV, Random, 95\% CI) & $0.16[0.02,0.30]$ \\
\hline 3 Cancer Site & 9 & 1249 & Std. Mean Difference (IV, Random, 95\% CI) & $0.11[-0.00,0.22]$ \\
\hline 3.1 Breast & 3 & 684 & Std. Mean Difference (IV, Random, 95\% CI) & $0.11[-0.11,0.34]$ \\
\hline 3.2 Other sites & 6 & 565 & Std. Mean Difference (IV, Random, 95\% CI) & $0.11[-0.07,0.28]$ \\
\hline 4 Type of Intervention & 9 & 1249 & Std. Mean Difference (IV, Random, 95\% CI) & $0.11[-0.00,0.22]$ \\
\hline 4.1 Cognitive Behavioural & 6 & 763 & Std. Mean Difference (IV, Random, 95\% CI) & $0.05[-0.10,0.20]$ \\
\hline \multicolumn{5}{|l|}{ Therapy } \\
\hline 4.2 Psychoeducation & 1 & 261 & Std. Mean Difference (IV, Random, 95\% CI) & $0.29[0.05,0.54]$ \\
\hline 4.3 Counseling & 2 & 225 & Std. Mean Difference (IV, Random, 95\% CI) & $0.08[-0.19,0.34]$ \\
\hline 5 Mode of Delivery & 9 & 1249 & Std. Mean Difference (IV, Random, 95\% CI) & $0.11[-0.00,0.22]$ \\
\hline 5.1 Telephone & 2 & 270 & Std. Mean Difference (IV, Random, 95\% CI) & $0.09[-0.19,0.36]$ \\
\hline 5.2 Face to Face & 5 & 439 & Std. Mean Difference (IV, Random, 95\% CI) & $0.12[-0.07,0.31]$ \\
\hline $\begin{array}{l}5.3 \text { Combination (Tel and } \\
\text { FTF) }\end{array}$ & 2 & 540 & Std. Mean Difference (IV, Random, 95\% CI) & $0.11[-0.24,0.46]$ \\
\hline 6 Discipline of 'Trained Helper' & 8 & 1215 & Std. Mean Difference (IV, Random, 95\% CI) & $0.10[-0.02,0.22]$ \\
\hline 6.1 Psychologist & 2 & 281 & Std. Mean Difference (IV, Random, 95\% CI) & $0.01[-0.25,0.27]$ \\
\hline 6.2 Nurse & 2 & 405 & Std. Mean Difference (IV, Random, 95\% CI) & $0.23[0.04,0.43]$ \\
\hline $6.3 \mathrm{GP}$ & 1 & 81 & Std. Mean Difference (IV, Random, 95\% CI) & $0.0[-0.44,0.44]$ \\
\hline $\begin{array}{l}\text { 6.4 Combination: Nurse, } \\
\text { Social Worker, Psychologist, } \\
\text { Medical Doctor }\end{array}$ & 3 & 448 & Std. Mean Difference (IV, Random, 95\% CI) & $0.10[-0.17,0.38]$ \\
\hline
\end{tabular}

\section{Comparison 2. Risk of bias}

\begin{tabular}{lccccc} 
Outcome or subgroup title & $\begin{array}{c}\text { No. of } \\
\text { studies }\end{array}$ & $\begin{array}{c}\text { No. of } \\
\text { participants }\end{array}$ & Statistical method & Effect size \\
\hline 1 Allocation Concealment & 4 & 499 & Std. Mean Difference (IV, Random, 95\% CI) & $0.01[-0.16,0.19]$ \\
2 Intention to Treat Analysis & 6 & 898 & Std. Mean Difference (IV, Random, 95\% CI) & $0.14[-0.03,0.31]$ \\
\hline
\end{tabular}

Psychosocial interventions to improve quality of life and emotional wellbeing for recently diagnosed cancer patients (Review) 


\begin{tabular}{lccccc} 
Outcome or subgroup title & $\begin{array}{c}\text { No. of } \\
\text { studies }\end{array}$ & $\begin{array}{c}\text { No. of } \\
\text { participants }\end{array}$ & Statistical method & Effect size \\
\hline 1 General Psychological Distress & 9 & 1502 & Std. Mean Difference (IV, Random, 95\% CI) & $0.08[-0.05,0.21]$ \\
$\begin{array}{l}\text { 1.1 Depression Specific } \\
\text { Measures }\end{array}$ & 6 & 1014 & Std. Mean Difference (IV, Random, 95\% CI) & $0.12[-0.07,0.31]$ \\
$\begin{array}{l}\text { 1.2 Anxiety Specific Measures } \\
\text { 2 Mood Measures }\end{array}$ & 4 & 488 & Std. Mean Difference (IV, Random, 95\% CI) & $0.05[-0.13,0.22]$ \\
\hline
\end{tabular}

\section{Analysis I.I. Comparison I Primary outcome: quality of life, Outcome I All Studies.}

Review: Psychosocial interventions to improve quality of life and emotional wellbeing for recently diagnosed cancer patients

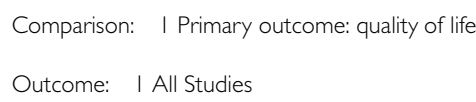

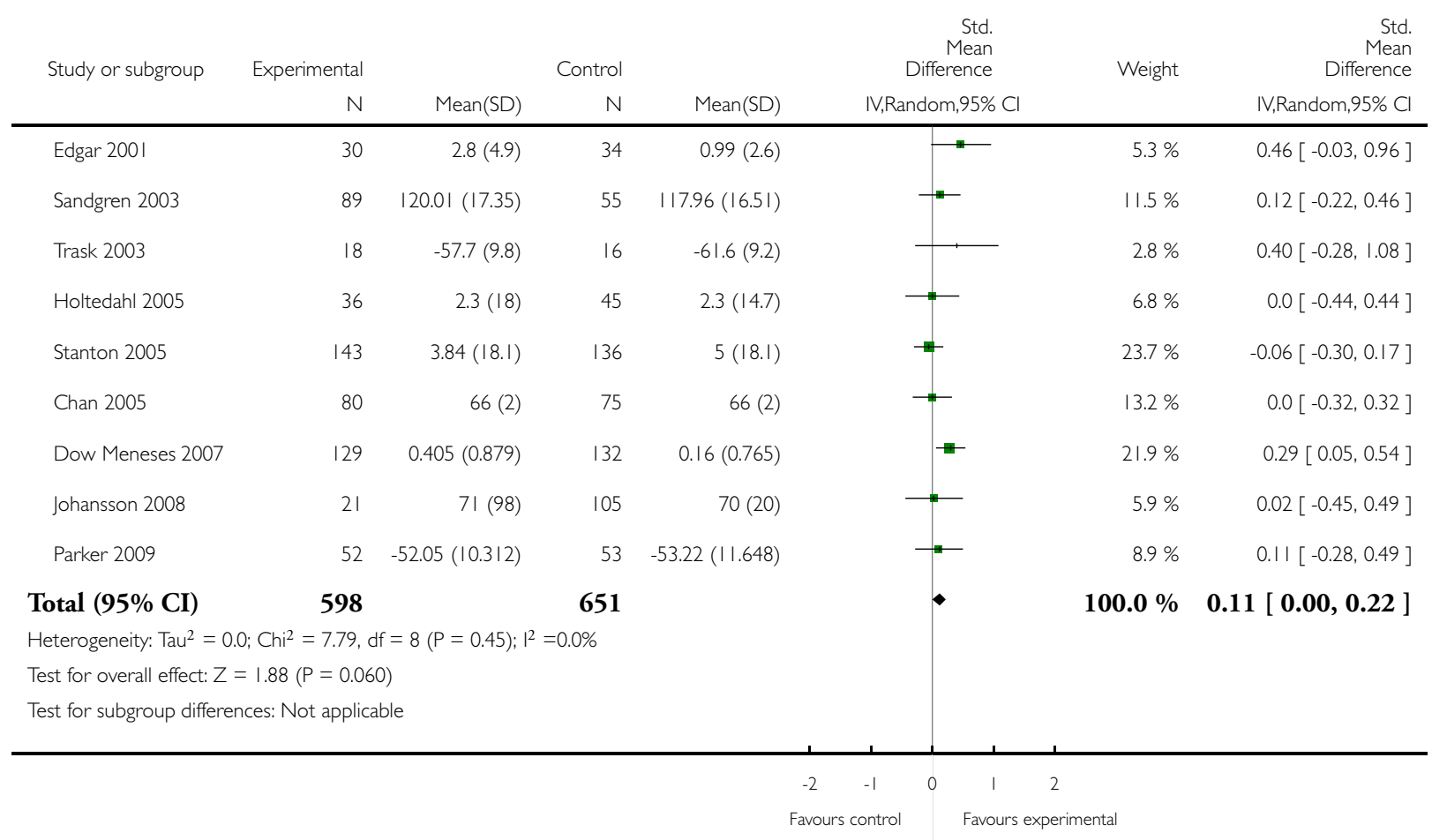




\section{Analysis I.2. Comparison I Primary outcome: quality of life, Outcome 2 Measures of Quality of Life.}

Review: Psychosocial interventions to improve quality of life and emotional wellbeing for recently diagnosed cancer patients

Comparison: I Primary outcome: quality of life

Outcome: 2 Measures of Quality of Life

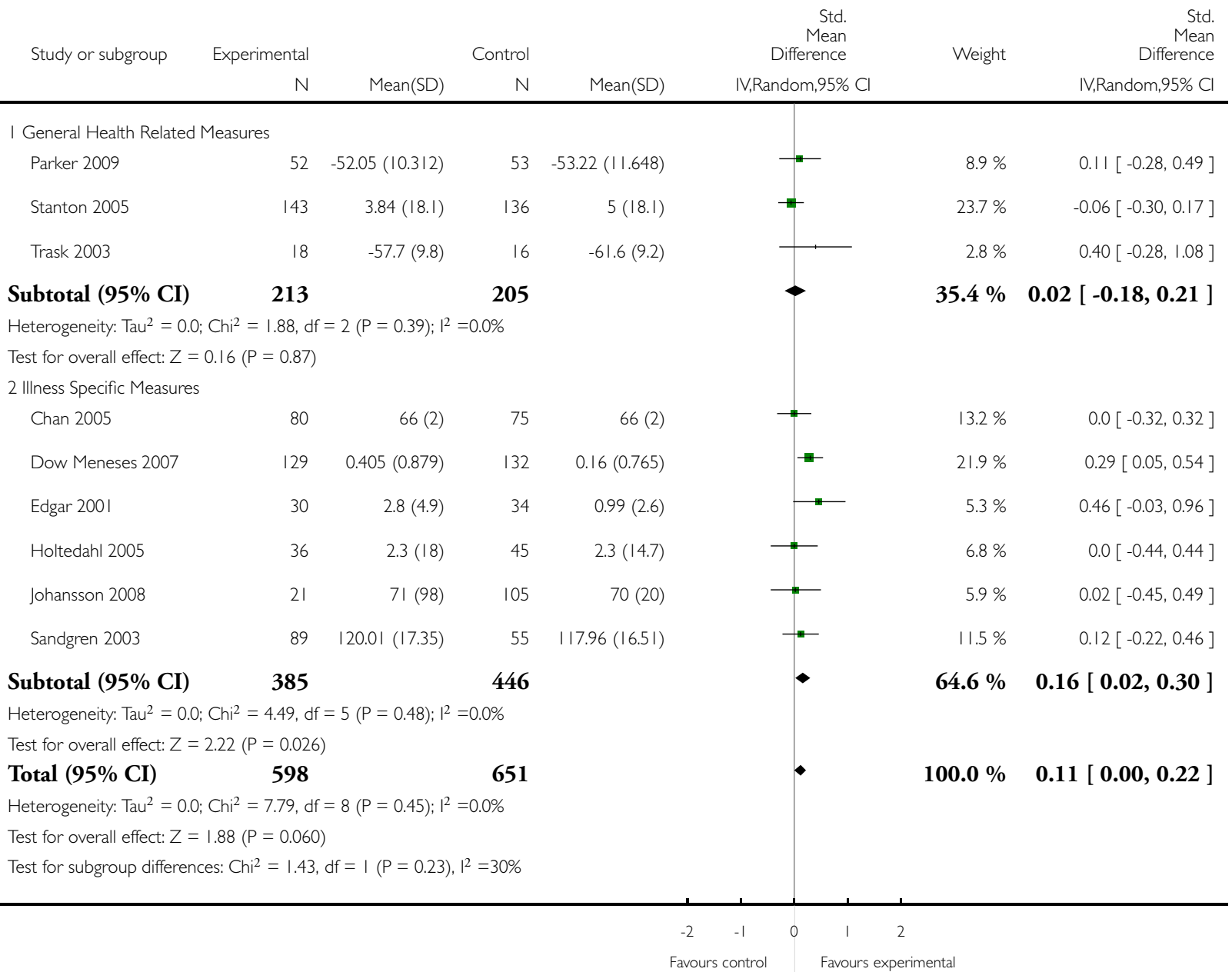

Psychosocial interventions to improve quality of life and emotional wellbeing for recently diagnosed cancer patients (Review) 


\section{Analysis I.3. Comparison I Primary outcome: quality of life, Outcome 3 Cancer Site.}

Review: Psychosocial interventions to improve quality of life and emotional wellbeing for recently diagnosed cancer patients

Comparison: I Primary outcome: quality of life

Outcome: 3 Cancer Site

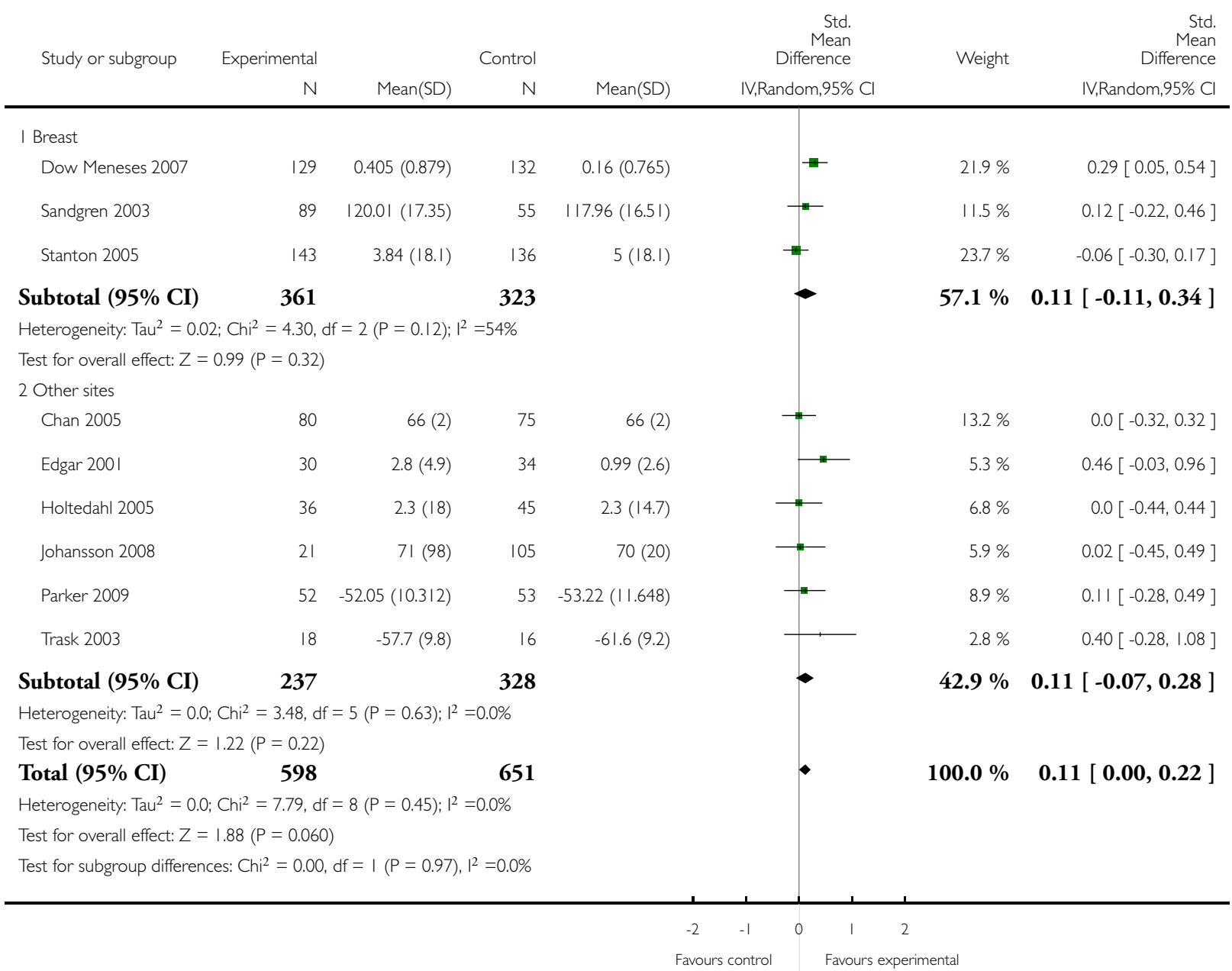

Psychosocial interventions to improve quality of life and emotional wellbeing for recently diagnosed cancer patients (Review) 


\section{Analysis I.4. Comparison I Primary outcome: quality of life, Outcome 4 Type of Intervention.}

Review: Psychosocial interventions to improve quality of life and emotional wellbeing for recently diagnosed cancer patients

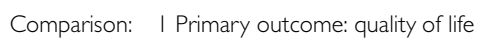

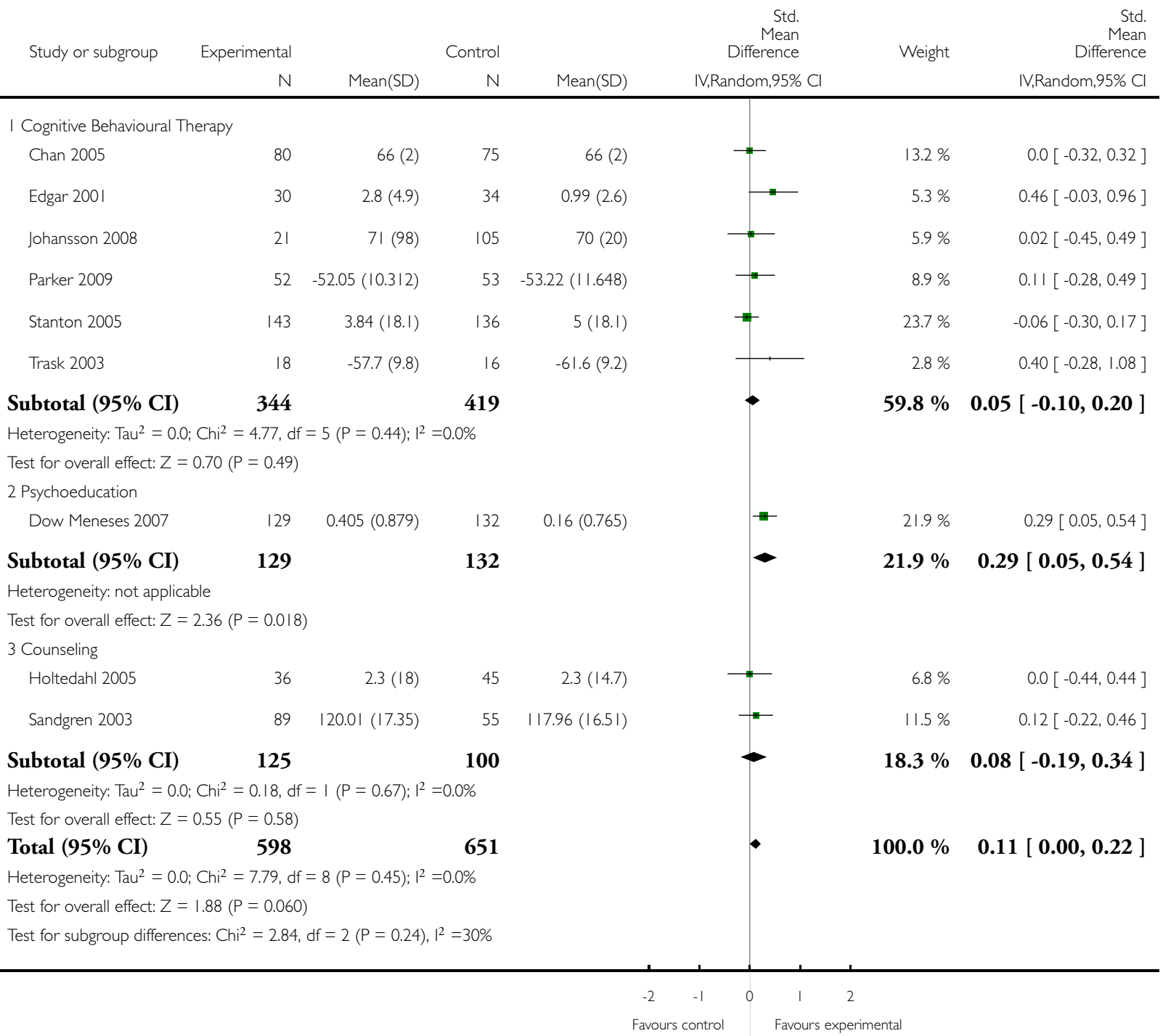




\section{Analysis I.5. Comparison I Primary outcome: quality of life, Outcome 5 Mode of Delivery.}

Review: Psychosocial interventions to improve quality of life and emotional wellbeing for recently diagnosed cancer patients

Comparison: I Primary outcome: quality of life

Outcome: 5 Mode of Delivery

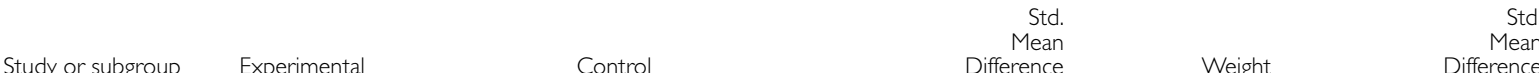

N Mean(SD) N $\quad$ Mean(SD) IV,Random,95\% C

IV,Random,95\% Cl

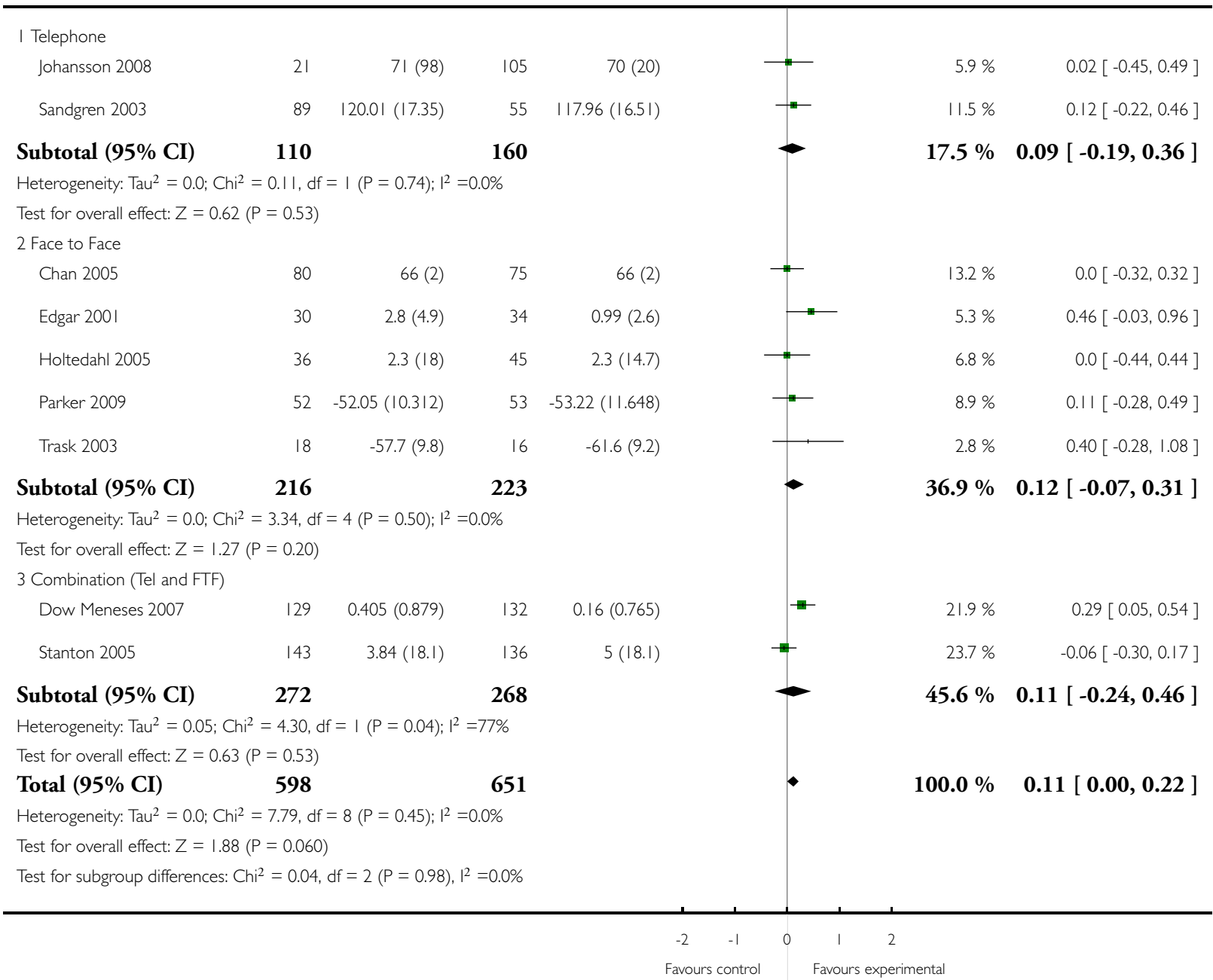

Psychosocial interventions to improve quality of life and emotional wellbeing for recently diagnosed cancer patients (Review) 


\section{Analysis I.6. Comparison I Primary outcome: quality of life, Outcome 6 Discipline of 'Trained Helper'.}

Review: Psychosocial interventions to improve quality of life and emotional wellbeing for recently diagnosed cancer patients

Comparison: I Primary outcome: quality of life

Outcome: 6 Discipline of 'Trained Helper'

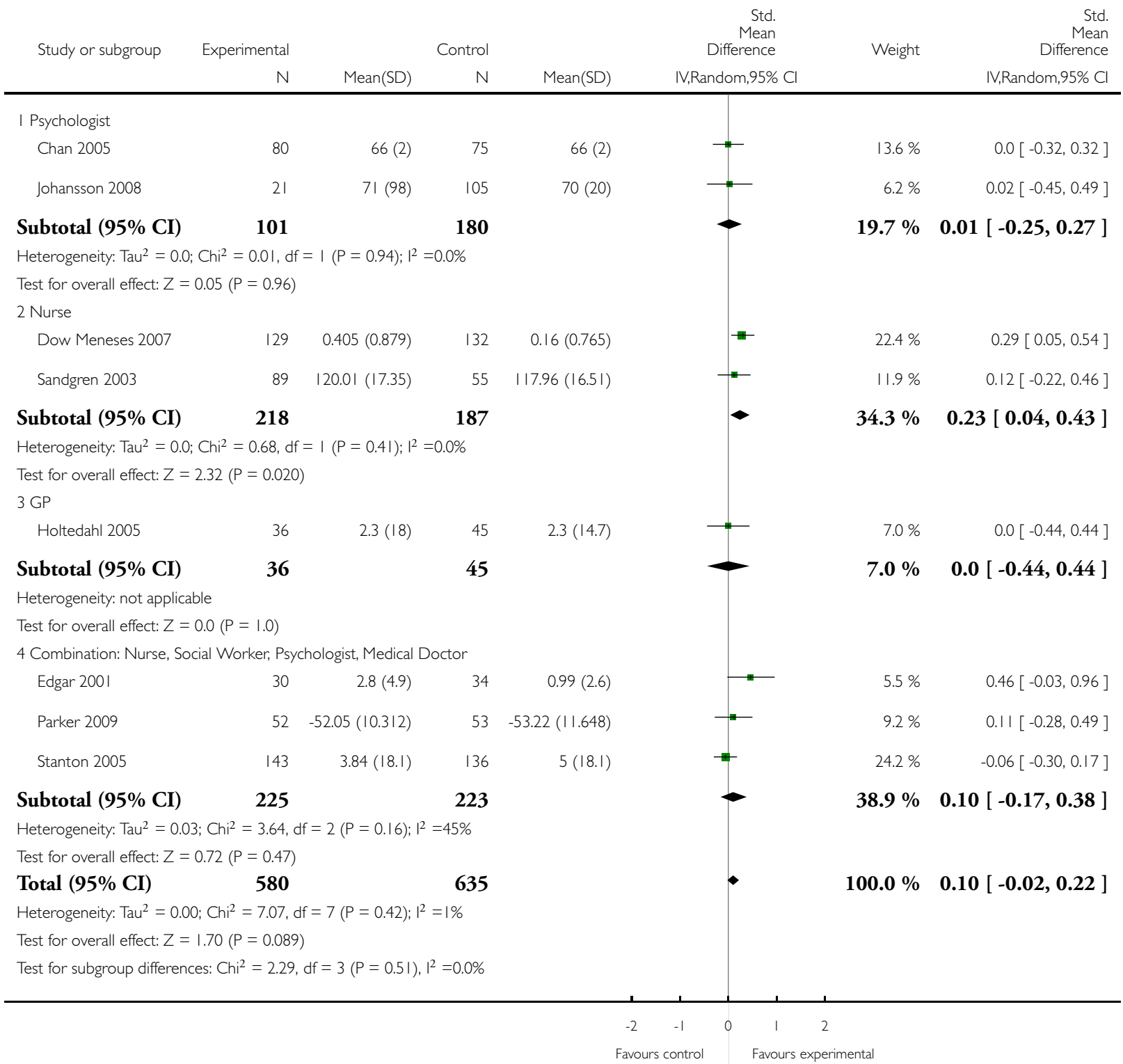

Psychosocial interventions to improve quality of life and emotional wellbeing for recently diagnosed cancer patients (Review) 


\section{Analysis 2.1. Comparison 2 Risk of bias, Outcome I Allocation Concealment.}

Review: Psychosocial interventions to improve quality of life and emotional wellbeing for recently diagnosed cancer patients

Comparison: 2 Risk of bias

Outcome: I Allocation Concealment

\begin{tabular}{|c|c|c|c|c|c|c|c|}
\hline \multirow[t]{2}{*}{ Study or subgroup } & \multirow{2}{*}{$\begin{array}{r}\text { Experimental } \\
N\end{array}$} & \multicolumn{3}{|c|}{ Control } & \multirow{2}{*}{$\begin{array}{r}\text { Std. } \\
\text { Mean } \\
\text { Difference } \\
\text { IV,Random,95\% Cl }\end{array}$} & \multirow[t]{2}{*}{ Weight } & \multirow{2}{*}{$\begin{array}{r}\text { Std. } \\
\text { Mean } \\
\text { Difference } \\
\text { IV,Random,95\% Cl }\end{array}$} \\
\hline & & Mean(SD) & $\mathrm{N}$ & Mean(SD) & & & \\
\hline Holtedahl 2005 & 36 & $2.3(18)$ & 45 & $2.3(14.7)$ & $\longrightarrow$ & $16.1 \%$ & $0.0[-0.44,0.44]$ \\
\hline Parker 2009 & 52 & $-52.05(10.312)$ & 53 & $-53.22(11.648)$ & & $21.1 \%$ & $0.11[-0.28,0.49]$ \\
\hline Stanton 2005 & 143 & $3.84(18.1)$ & 136 & $5(\mid 8.1)$ & 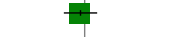 & $56.1 \%$ & $-0.06[-0.30,0.17]$ \\
\hline Trask 2003 & 18 & $-57.7(9.8)$ & 16 & $-61.6(9.2)$ & & $6.7 \%$ & $0.40[-0.28,1.08]$ \\
\hline Total $(95 \%$ CI $)$ & 249 & & 250 & & 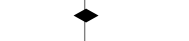 & $100.0 \%$ & $0.01[-0.16,0.19]$ \\
\hline \multicolumn{8}{|c|}{ Heterogeneity: $\operatorname{Tau}^{2}=0.0 ; \mathrm{Chi}^{2}=1.88, \mathrm{df}=3(\mathrm{P}=0.60) ;\left.\right|^{2}=0.0 \%$} \\
\hline \multicolumn{8}{|c|}{ Test for overall effect: $Z=0.15(P=0.88)$} \\
\hline \multicolumn{8}{|c|}{ Test for subgroup differences: Not applicable } \\
\hline & & & & & -1 & 2 & \\
\hline \multicolumn{8}{|c|}{ Favours control } \\
\hline
\end{tabular}

Psychosocial interventions to improve quality of life and emotional wellbeing for recently diagnosed cancer patients (Review) 


\section{Analysis 2.2. Comparison 2 Risk of bias, Outcome 2 Intention to Treat Analysis.}

Review: Psychosocial interventions to improve quality of life and emotional wellbeing for recently diagnosed cancer patients

Comparison: 2 Risk of bias

Outcome: 2 Intention to Treat Analysis

\begin{tabular}{|c|c|c|c|c|c|c|c|}
\hline \multirow[t]{2}{*}{ Study or subgroup } & \multirow{2}{*}{$\begin{array}{r}\text { Experimental } \\
\mathrm{N}\end{array}$} & \multicolumn{3}{|c|}{ Control } & $\begin{array}{r}\text { Std. } \\
\text { Mean } \\
\text { Difference }\end{array}$ & \multirow[t]{2}{*}{ Weight } & \multirow{2}{*}{$\begin{array}{r}\text { Std. } \\
\text { Mean } \\
\text { Difference } \\
\text { IV,Random,95\% Cl }\end{array}$} \\
\hline & & Mean(SD) & $\mathrm{N}$ & Mean(SD) & IV,Random,95\% Cl & & \\
\hline Chan 2005 & 80 & $66(2)$ & 75 & $66(2)$ & $\longrightarrow$ & $18.8 \%$ & $0.0[-0.32,0.32]$ \\
\hline Dow Meneses 2007 & 129 & $0.405(0.879)$ & 132 & $0.16(0.765)$ & \# & $25.4 \%$ & $0.29[0.05,0.54]$ \\
\hline Edgar 200I & 30 & $2.8(4.9)$ & 34 & $0.99(2.6)$ & $\longrightarrow$ & $9.5 \%$ & $0.46[-0.03,0.96]$ \\
\hline Parker 2009 & 52 & $-52.05(10.312)$ & 53 & $-53.22(11.648)$ & $\longrightarrow$ & $14.3 \%$ & $0.11[-0.28,0.49]$ \\
\hline Stanton 2005 & 143 & $3.84(18.1)$ & 136 & $5(\mid 8.1)$ & 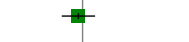 & $26.4 \%$ & $-0.06[-0.30,0.17]$ \\
\hline Trask 2003 & 18 & $-57.7(9.8)$ & 16 & $-61.6(9.2)$ & $\longrightarrow$ & $5.5 \%$ & $0.40[-0.28,1.08]$ \\
\hline Total (95\% CI) & 452 & & 446 & & - & $100.0 \%$ & $0.14[-0.03,0.31]$ \\
\hline \multicolumn{8}{|c|}{ Heterogeneity: $\mathrm{Tau}^{2}=0.0 \mathrm{I} ; \mathrm{Chi}^{2}=7.36, \mathrm{df}=5(\mathrm{P}=0.20) ; \mathrm{I}^{2}=32 \%$} \\
\hline \multicolumn{8}{|c|}{ Test for overall effect: $Z=1.61(P=0.11)$} \\
\hline \multicolumn{8}{|c|}{ Test for subgroup differences: Not applicable } \\
\hline & & & & & -1 & 2 & \\
\hline
\end{tabular}

Psychosocial interventions to improve quality of life and emotional wellbeing for recently diagnosed cancer patients (Review) 


\section{Analysis 3.I. Comparison 3 Secondary outcomes, Outcome I General Psychological Distress.}

Review: Psychosocial interventions to improve quality of life and emotional wellbeing for recently diagnosed cancer patients

Comparison: 3 Secondary outcomes

Outcome: I General Psychological Distress

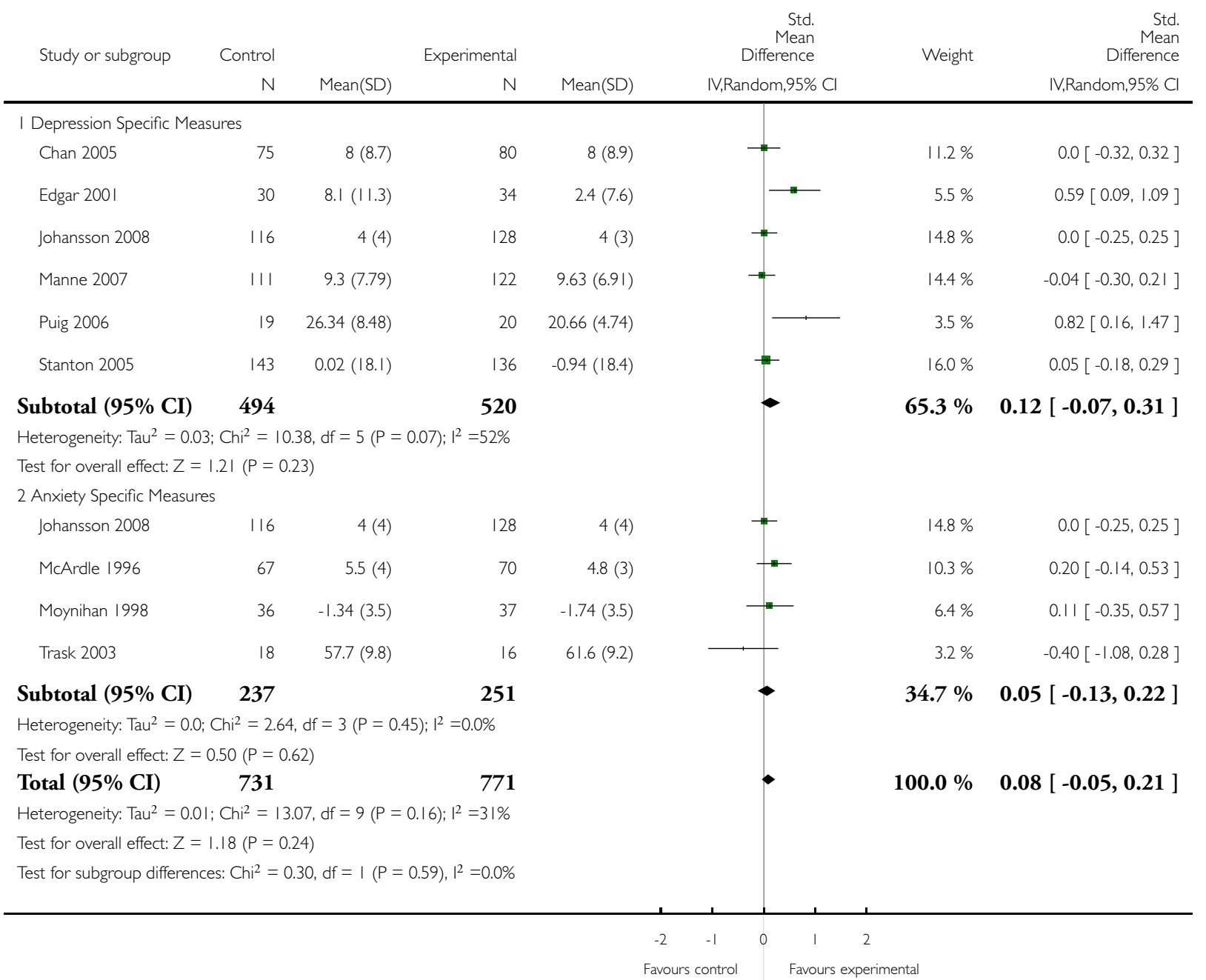

Psychosocial interventions to improve quality of life and emotional wellbeing for recently diagnosed cancer patients (Review) 


\section{Analysis 3.2. Comparison 3 Secondary outcomes, Outcome 2 Mood Measures.}

Review: Psychosocial interventions to improve quality of life and emotional wellbeing for recently diagnosed cancer patients

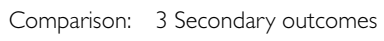

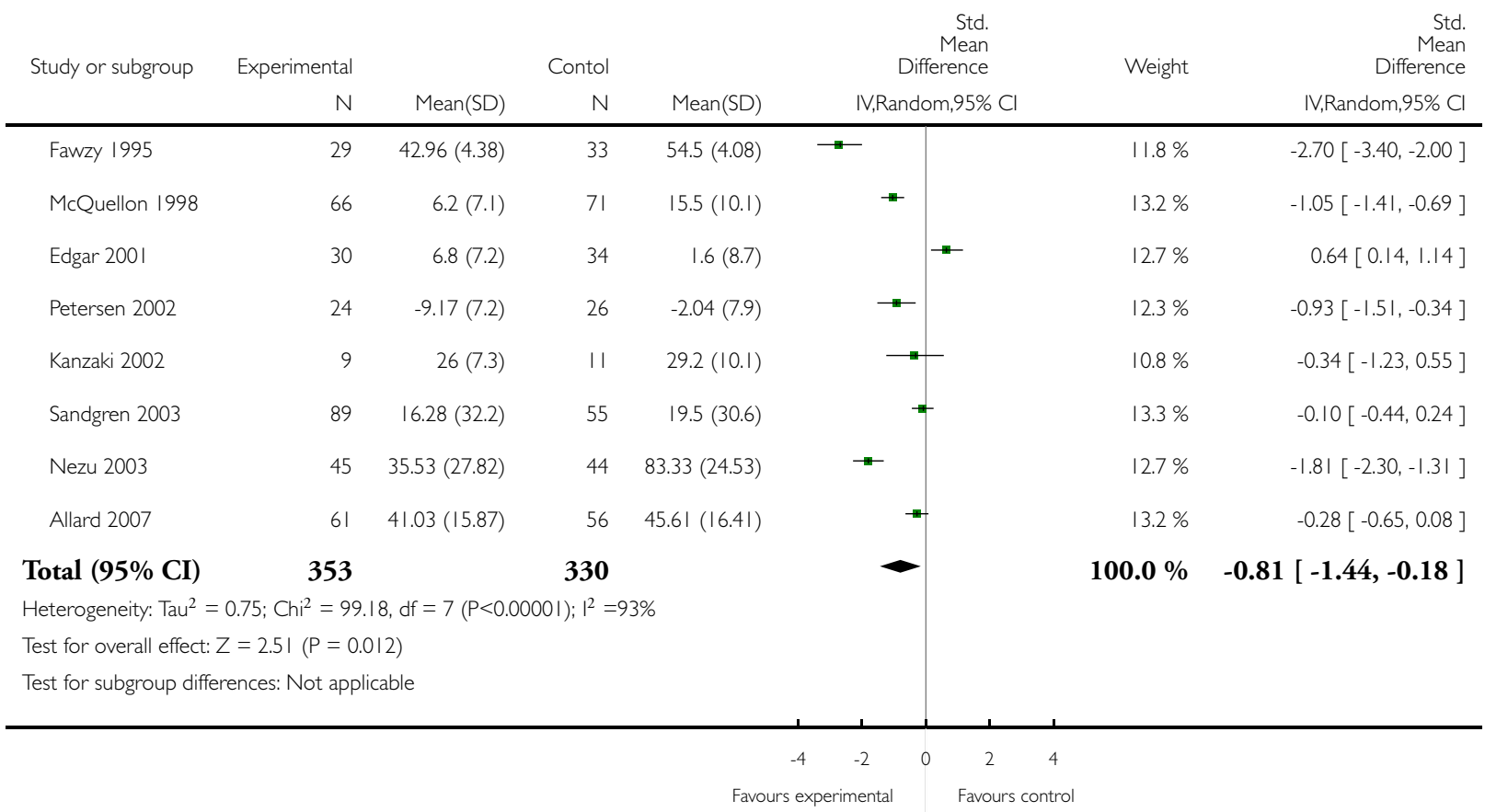

\section{ADDITIONAL TABLES}

Table 1. Features of studies included in review: data not suitable for meta-analyses

\begin{tabular}{|c|c|c|c|c|c|c|c|}
\hline $\begin{array}{l}\text { 1st Author } \\
\text { Year } \\
\text { Country } \\
\text { Language }\end{array}$ & $\mathbf{N}$ & Cancer site & Mode & no of contacts & Follow ups & Discipline & Classification \\
\hline $\begin{array}{l}\text { Sandgren } \\
2000 \\
\text { USA } \\
\text { English }\end{array}$ & 53 & Breast & telephone & $\begin{array}{l}10 \mathrm{x} 30 \mathrm{mins} \\
\text { (weekly, then bi- } \\
\text { weekly - over } 16 \\
\text { weeks) }\end{array}$ & 3 & psychologist & CBT \\
\hline $\begin{array}{l}\text { Burton } \\
1995 \\
\text { UK }\end{array}$ & 200 & breast & face-to-face & $\begin{array}{l}\operatorname{grp} 1 \& 2= \\
2 \times 30 \mathrm{~min}, \operatorname{grp} 3=\end{array}$ & 2 & MD & Preparation \\
\hline
\end{tabular}

Copyright () 2012 The Cochrane Collaboration. Published by John Wiley \& Sons, Ltd. 
Table 1. Features of studies included in review: data not suitable for meta-analyses

(Continued)

\begin{tabular}{|c|c|c|c|c|c|c|c|}
\hline English & & & & $1 \times 30 \mathrm{~min}$ & & & \\
\hline $\begin{array}{l}\text { Forester } \\
1985 \\
\text { USA } \\
\text { English }\end{array}$ & 100 & $\begin{array}{l}\text { lung, } \\
\text { prostate, uterus, } \\
\text { bladder, cervix, } \\
\text { ovary, other }\end{array}$ & face-to-face & 10 (10 weeks) & 4 & MD & Preparation \\
\hline $\begin{array}{l}\text { Jacobsen } \\
2002 \\
\text { USA } \\
\text { English }\end{array}$ & 382 & $\begin{array}{l}\text { breast, lung, } \\
\text { ovar- } \\
\text { ian, lymphoma, } \\
\text { colon, prostate, } \\
\text { endometrial, } \\
\text { other }\end{array}$ & face-to-face & $\begin{array}{l}1 \times 60 \text { mins } \\
+5 \text { mins at each } \\
\text { chemo session }\end{array}$ & 4 & psychologist & Preparation \\
\hline $\begin{array}{l}\text { Lee } \\
2006 \\
\text { Canada } \\
\text { English }\end{array}$ & 82 & $\begin{array}{l}\text { Breast \& col- } \\
\text { orectal }\end{array}$ & face-to-face & $\begin{array}{l}4 \quad \mathrm{x} \text { up } \\
\text { to } 120 \text { mins (un- } \\
\text { clear over what } \\
\text { period) }\end{array}$ & 1 & nurse & Meaning-making \\
\hline $\begin{array}{l}\text { Lev } \\
2000 \\
\text { USA } \\
\text { English }\end{array}$ & 18 & Breast & combination & $\begin{array}{l}\text { videotape, book- } \\
\text { let, } 5 \text { counselling } \\
\text { sessions } \\
\text { (monthly) }\end{array}$ & 2 & nurse & CBT \\
\hline $\begin{array}{l}\text { Linn } \\
1981 \\
\text { USA } \\
\text { English }\end{array}$ & 120 & $\begin{array}{l}\text { lung, } \\
\text { colon, stomach, } \\
\text { prostate, blad- } \\
\text { der \& unknown }\end{array}$ & face-to-face & $\begin{array}{l}\text { sev- } \\
\text { eral times a week } \\
\text { (no description } \\
\text { of length) }\end{array}$ & 5 & social worker & Counselling \\
\hline $\begin{array}{l}\text { Mischel } \\
2002 \\
\text { USA } \\
\text { English }\end{array}$ & 239 & prostate & combination & $\begin{array}{l}8 \text { weekly phone } \\
\text { calls (supple- } \\
\text { mental audio/ } \\
\text { video tapes pro- } \\
\text { vided) }\end{array}$ & 2 & nurse & CBT \\
\hline $\begin{array}{l}\text { Ross } \\
2005 \\
\text { Denmark } \\
\text { English }\end{array}$ & 249 & colon & face-to-face & $\begin{array}{l}10 \quad(5 \text { in } 1 \text { st } \\
12 \text { weeks, and } \\
5 \text { over follow- } \\
\text { ing } 18 \text { mths+op- } \\
\text { tion of telephone } \\
\text { calls) }\end{array}$ & 4 & nurse & Counselling \\
\hline $\begin{array}{l}\text { Sandgren } \\
2007 \\
\text { USA } \\
\text { English }\end{array}$ & 218 & Breast & telephone & $\begin{array}{l}6 \times 30 \text { mins }(5 \\
\text { weekly, then fi- } \\
\text { nal call at } 3 \\
\text { months) }\end{array}$ & 1 & nurse & Counselling \\
\hline
\end{tabular}


Table 1. Features of studies included in review: data not suitable for meta-analyses

(Continued)

\begin{tabular}{|c|c|c|c|c|c|c|c|}
\hline $\begin{array}{l}\text { Scholten } \\
2001 \\
\text { Austria } \\
\text { English }\end{array}$ & 84 & Breast & face-to-face & $\begin{array}{l}\text { maxi- } \\
\text { mum } 4 \text { (83\% 2- } \\
4 \text { contacts) }\end{array}$ & 2 & psychologist & CBT \\
\hline $\begin{array}{l}\text { Scura } \\
2004 \\
\text { USA } \\
\text { English }\end{array}$ & 17 & prostate & telephone & $\begin{array}{l}10 \text { weekly, } 10 \text { bi- } \\
\text { weekly, monthly } \\
\text { (up to } 12 \\
\text { months) }\end{array}$ & 3 & Researcher & Other \\
\hline
\end{tabular}

Table 2. Studies included in the review: data suitable for meta-analyses

\begin{tabular}{|c|c|c|c|c|c|c|c|c|c|c|c|}
\hline $\begin{array}{l}\text { 1st Au- } \\
\text { thor } \\
\text { Year } \\
\text { Country } \\
\text { Lan- } \\
\text { guage }\end{array}$ & $\mathrm{N}$ & $\begin{array}{l}\text { Cancer } \\
\text { site }\end{array}$ & Mode & $\begin{array}{l}\text { no of } \\
\text { contacts }\end{array}$ & $\begin{array}{l}\text { Follow } \\
\text { ups }\end{array}$ & $\begin{array}{l}\text { Disci- } \\
\text { pline }\end{array}$ & $\begin{array}{l}\text { Classifi- } \\
\text { cation }\end{array}$ & $\begin{array}{l}\text { Qol } \\
\text { Measure }\end{array}$ & $\begin{array}{l}\text { Fol- } \\
\text { low up in } \\
\text { weeks }\end{array}$ & $\begin{array}{l}\text { Gen- } \\
\text { eral Psy- } \\
\text { cholog- } \\
\text { ical State } \\
\text { Measure }\end{array}$ & $\begin{array}{l}\text { Fol- } \\
\text { low up in } \\
\text { Weeks }\end{array}$ \\
\hline $\begin{array}{l}\text { Allard } \\
2007 \\
\text { Canada } \\
\text { English }\end{array}$ & 117 & breast & $\begin{array}{l}\text { tele- } \\
\text { phone }\end{array}$ & $\begin{array}{l}2 \times \text { tele- } \\
\text { phone } \\
\text { calls }(3 \mathrm{x} \\
\text { data col- } \\
\text { lection } \\
\text { research } \\
\text { calls) }\end{array}$ & 2 & nurse & $\begin{array}{l}\text { Counsel- } \\
\text { ing } \\
\text { (prepara- } \\
\text { tion) }\end{array}$ & & & POMS & 2 \\
\hline $\begin{array}{l}\text { Chan } \\
2005 \\
\text { China } \\
\text { English }\end{array}$ & 155 & $\begin{array}{l}\text { ovary, } \\
\text { cervix, } \\
\text { corpus }\end{array}$ & $\begin{array}{l}\text { face-to- } \\
\text { face }\end{array}$ & $\begin{array}{l}\text { bi- } \\
\text { weekly } \\
\text { dur- } \\
\text { ing treat- } \\
\text { ment, 6- } \\
\text { weekly } \\
\text { post- } \\
\text { treat- } \\
\text { ment, up } \\
\text { to } 18 \\
\text { months }\end{array}$ & 6 & $\begin{array}{l}\text { psychol- } \\
\text { ogist }\end{array}$ & CBT & $\begin{array}{l}\text { EORTC } \\
\text { QLQ-30 }\end{array}$ & 24 & BDI & 24 \\
\hline $\begin{array}{l}\text { Dow } \\
\text { Meneses } \\
2007 \\
\text { USA } \\
\text { English }\end{array}$ & 256 & Breast & $\begin{array}{l}\text { combi- } \\
\text { nation }\end{array}$ & $\begin{array}{l}7 ; 3 \text { face } \\
\text { to face, } 2 \\
\text { tele- } \\
\text { phone, } \\
2 \text { face to } \\
\text { face fol- } \\
\text { low up }\end{array}$ & 2 & nurse & $\begin{array}{l}\text { psy- } \\
\text { cho edu- } \\
\text { cation }\end{array}$ & $\begin{array}{l}\text { QoL } \\
\text { Breast } \\
\text { Can- } \\
\text { cer Sur- } \\
\text { vivors } \\
\text { Scale }\end{array}$ & 24 & & \\
\hline
\end{tabular}


Table 2. Studies included in the review: data suitable for meta-analyses (Continued)

\begin{tabular}{|c|c|c|c|c|c|c|c|c|c|c|c|}
\hline $\begin{array}{l}\text { Downe- } \\
\text { Wambolt } \\
2007 \\
\text { Canada } \\
\text { English }\end{array}$ & 175 & $\begin{array}{l}\text { lung, } \\
\text { prostate, } \\
\text { breast }\end{array}$ & $\begin{array}{l}\text { tele- } \\
\text { phone }\end{array}$ & $\begin{array}{l}\text { var- } \\
\text { ious } 57 \% \\
>5 \quad(3 \\
\text { month } \\
\text { period) }\end{array}$ & 1 & nurse & CBT & & & CES-D & 32 \\
\hline $\begin{array}{l}\text { Edgar } \\
2001 \\
\text { Canada } \\
\text { English }\end{array}$ & 225 & $\begin{array}{l}\text { breast, } \\
\text { colon }\end{array}$ & $\begin{array}{l}\text { face-to- } \\
\text { face }\end{array}$ & $\begin{array}{l}5 \\
\text { month } \\
\text { period) }\end{array}$ & 3 & $\begin{array}{l}\text { combi- } \\
\text { nation }\end{array}$ & CBT & $\begin{array}{l}\text { FACT } \\
(\mathrm{Em})\end{array}$ & 52 & POMS & 32 \\
\hline $\begin{array}{l}\text { Fawzy } \\
1995 \\
\text { USA } \\
\text { English }\end{array}$ & 61 & skin & $\begin{array}{l}\text { face-to- } \\
\text { face }\end{array}$ & $\begin{array}{l}2 \text { (+op- } \\
\text { tion of } \\
\text { tele- } \\
\text { phone } \\
\text { calls to } \\
\text { nurse) }\end{array}$ & 2 & nurse & CBT & & & POMS & 12 \\
\hline $\begin{array}{l}\text { Holted- } \\
\text { hal } \\
2005 \\
\text { Norway } \\
\text { English }\end{array}$ & 91 & $\begin{array}{l}\text { all cancer } \\
\text { sites }\end{array}$ & $\begin{array}{l}\text { face-to- } \\
\text { face }\end{array}$ & 2 & 1 & MD & $\begin{array}{l}\text { Coun- } \\
\text { selling }\end{array}$ & $\begin{array}{l}\text { EORTC } \\
\text { QLQ-30 }\end{array}$ & 24 & & \\
\hline $\begin{array}{l}\text { Johans- } \\
\text { son } \\
2008 \\
\text { Sweden } \\
\text { English }\end{array}$ & 481 & $\begin{array}{l}\text { breast, } \\
\text { GI= col- } \\
\text { orectal or } \\
\text { gastric, } \\
\text { prostate }\end{array}$ & $\begin{array}{l}\text { combi- } \\
\text { nation }\end{array}$ & $\begin{array}{l}\text { median= } \\
3 \text { (range } \\
1-24)\end{array}$ & 4 & $\begin{array}{l}\text { Psychol- } \\
\text { ogist }\end{array}$ & CBT & $\begin{array}{l}\text { EORTC } \\
\text { QLQ-30 }\end{array}$ & 24 & $\begin{array}{l}\text { HADS } \\
\text { (Depres- } \\
\text { sion, } \\
\text { Anxiety) }\end{array}$ & 24 \\
\hline $\begin{array}{l}\text { Kanzaki } \\
2002 \\
\text { Japan } \\
\text { Japanese }\end{array}$ & 26 & gastric & $\begin{array}{l}\text { face-to- } \\
\text { face }\end{array}$ & $\begin{array}{l}5 \text { (5 week } \\
\text { period) }\end{array}$ & 2 & nurse & CBT & & & DAMS & 4 \\
\hline $\begin{array}{l}\text { Manne } \\
2007 \\
\text { USA } \\
\text { English }\end{array}$ & 353 & $\begin{array}{l}\text { gynaeco- } \\
\text { logical }\end{array}$ & $\begin{array}{l}\text { combi- } \\
\text { nation }\end{array}$ & $\begin{array}{l}6 \times 60 \\
\text { mins }(+ \\
1 \times \text { tele- } \\
\text { phone } \\
\text { call at the } \\
\text { end) }\end{array}$ & 3 & $\begin{array}{l}\text { combi- } \\
\text { nation }\end{array}$ & $\begin{array}{l}\text { Counsel- } \\
\text { ing }\end{array}$ & & & BDI & 24 \\
\hline $\begin{array}{l}\text { McArdle } \\
1996 \\
\text { UK } \\
\text { English }\end{array}$ & 272 & breast & $\begin{array}{l}\text { face-to- } \\
\text { face }\end{array}$ & $\begin{array}{l}1 \times 20-30 \\
\text { minutes } \\
\& \text { as nec- } \\
\text { essary af- } \\
\text { ter that }\end{array}$ & 4 & nurse & $\begin{array}{l}\text { Counsel- } \\
\text { ing } \\
\text { (prepara- } \\
\text { tion) }\end{array}$ & & & $\begin{array}{l}\text { HADS } \\
\text { (Anxi- } \\
\text { ety) }\end{array}$ & 52 \\
\hline
\end{tabular}


Table 2. Studies included in the review: data suitable for meta-analyses

\begin{tabular}{|c|c|c|c|c|c|c|c|c|c|c|c|}
\hline $\begin{array}{l}\text { Mc- } \\
\text { Quellon } \\
1998 \\
\text { USA } \\
\text { English }\end{array}$ & 150 & $\begin{array}{l}\text { all cancer } \\
\text { sites }\end{array}$ & $\begin{array}{l}\text { face-to- } \\
\text { face }\end{array}$ & $\begin{array}{l}1 \text { orien- } \\
\text { ta- } \\
\text { tion Pro- } \\
\text { gramme } \\
\text { includ- } \\
\text { ing time } \\
\text { with an } \\
\text { oncology } \\
\text { counsel- } \\
\text { lor to ex- } \\
\text { press } \\
\text { concerns }\end{array}$ & 1 & $\begin{array}{l}\text { counsel- } \\
\text { lor }\end{array}$ & $\begin{array}{l}\text { Counsel- } \\
\text { ing } \\
\text { (prepara- } \\
\text { tion) }\end{array}$ & & & POMS & $<1$ \\
\hline $\begin{array}{l}\text { Moyni- } \\
\text { han } \\
1998 \\
\text { UK } \\
\text { English }\end{array}$ & 73 & testicular & $\begin{array}{l}\text { face-to- } \\
\text { face }\end{array}$ & $\begin{array}{l}6 \times 60 \\
\text { mins }\end{array}$ & 3 & nurse & CBT & & & $\begin{array}{l}\text { HADS } \\
\text { (Anxi- } \\
\text { ety) }\end{array}$ & 16 \\
\hline $\begin{array}{l}\text { Nezu } \\
2003 \\
\text { USA } \\
\text { English }\end{array}$ & 150 & $\begin{array}{l}\text { breast, } \\
\text { leukaemia, } \\
\text { lung, } \\
\text { ovarian, } \\
\text { head/ } \\
\text { neck, } \\
\text { prostate, } \\
\text { non- } \\
\text { Hodgkins, } \\
\text { colon }\end{array}$ & $\begin{array}{l}\text { face-to- } \\
\text { face }\end{array}$ & $\begin{array}{l}10 \quad(10 \\
\text { weeks) } \mathrm{x} \\
90 \mathrm{mins}\end{array}$ & 3 & $\begin{array}{l}\text { psychol- } \\
\text { ogist }\end{array}$ & CBT & & & POMS & 24 \\
\hline $\begin{array}{l}\text { Parker } \\
2009 \\
\text { USA } \\
\text { English }\end{array}$ & 159 & prostate & $\begin{array}{l}\text { face-to- } \\
\text { face }\end{array}$ & 4 & 3 & $\begin{array}{l}\text { Combi- } \\
\text { nation }\end{array}$ & $\begin{array}{l}\text { CBT } \\
\text { (prepara- } \\
\text { tion) }\end{array}$ & $\begin{array}{l}\text { SF-36 } \\
\text { MCS }\end{array}$ & 24 & & \\
\hline $\begin{array}{l}\text { Peterson } \\
2002 \\
\text { Australia } \\
\text { English }\end{array}$ & 53 & $\begin{array}{l}\text { gynaeco- } \\
\text { logical }\end{array}$ & $\begin{array}{l}\text { face-to- } \\
\text { face }\end{array}$ & $\begin{array}{l}1 \times 60 \\
\operatorname{mins}\end{array}$ & 1 & MD & $\begin{array}{l}\text { Coun- } \\
\text { selling }\end{array}$ & & & GHQ & 24 \\
\hline $\begin{array}{l}\text { Puig } \\
2006 \\
\text { USA } \\
\text { English }\end{array}$ & 39 & Breast & $\begin{array}{l}\text { face-to- } \\
\text { face }\end{array}$ & $\begin{array}{l}4 \times 60 \\
\text { mins }\end{array}$ & 1 & $\begin{array}{l}\text { counsel- } \\
\text { lor }\end{array}$ & $\begin{array}{l}\text { psy- } \\
\text { cho edu- } \\
\text { cation/ } \\
\text { Creative } \\
\text { Arts }\end{array}$ & & & $\begin{array}{l}\text { POMS } \\
\text { (Depres- } \\
\text { sion- } \\
\text { dejec- } \\
\text { tion) }\end{array}$ & 4 \\
\hline $\begin{array}{l}\text { Sand- } \\
\text { gren } \\
2003\end{array}$ & 222 & Breast & $\begin{array}{l}\text { tele- } \\
\text { phone }\end{array}$ & $\begin{array}{l}6 \\
\times 30 \mathrm{mins} \\
(5\end{array}$ & 1 & nurse & $\begin{array}{l}\text { Coun- } \\
\text { selling }\end{array}$ & FACT-B & 24 & POMS & \\
\hline
\end{tabular}

Psychosocial interventions to improve quality of life and emotional wellbeing for recently diagnosed cancer patients (Review)

Copyright (c) 2012 The Cochrane Collaboration. Published by John Wiley \& Sons, Ltd. 
Table 2. Studies included in the review: data suitable for meta-analyses (Continued)

\begin{tabular}{|c|c|c|c|c|c|c|c|c|c|c|c|}
\hline $\begin{array}{l}\text { USA } \\
\text { English }\end{array}$ & & & & $\begin{array}{l}\text { weekly, } \\
\text { then fi- } \\
\text { nal call at } \\
3 \\
\text { months) }\end{array}$ & & & & & & & \\
\hline $\begin{array}{l}\text { Stanton } \\
2005 \\
\text { USA } \\
\text { English }\end{array}$ & 558 & Breast & $\begin{array}{l}\text { combi- } \\
\text { nation }\end{array}$ & $\begin{array}{l}2: \\
\text { one face- } \\
\text { to-face } \\
\text { meeting, } \\
\text { a video\& } \\
\text { man- } \\
\text { ual pro- } \\
\text { vided, } \\
\text { follow up } \\
\text { face-to- } \\
\text { face } \\
\text { meeting }\end{array}$ & 3 & $\begin{array}{l}\text { combi- } \\
\text { nation }\end{array}$ & CBT & $\begin{array}{l}\text { SF-36 } \\
\text { Vitality }\end{array}$ & 24 & & \\
\hline $\begin{array}{l}\text { Trask } \\
2003 \\
\text { USA } \\
\text { English }\end{array}$ & 48 & skin & $\begin{array}{l}\text { face-to- } \\
\text { face }\end{array}$ & $\begin{array}{l}4 \times 50 \\
\text { mins }\end{array}$ & 2 & $\begin{array}{l}\text { not } \\
\text { stated }\end{array}$ & CBT & SF-36 & 24 & STAI & 24 \\
\hline
\end{tabular}

\section{A P PENDICES}

\section{Appendix I. MEDLINE search strategy}

Medline on Ovid

1 psychosocial intervention*.mp.

2 psychosocial support system*.mp. or Social Support/\#

3 self help group*.mp. or Self-Help Groups/

4 educational therapy.mp.

5 Psycotherapy/ or psychoeducational.mp.

6 behavio*r therapy.mp. or Behavior Therapy/.

7 cognitive behavio*r therapy.mp. or Cognitive Therapy/

8 CBT.mp.

9 cognition therapy.mp.

10 family therapy.mp. or Family Therapy/

11 psychoanalytic therapy.mp. or Psychoanalytic Therapy/

12 Counseling/ or counselling.mp.

13 mental health services.mp. or Mental Health Services/

141 or 2 or 3 or 4 or 5 or 6 or 7 or 8 or 9 or 10 or 11 or 12 or 13

15 quality of life.mp. or "Quality of Life"/ 16 QoL.mp.

Copyright @ 2012 The Cochrane Collaboration. Published by John Wiley \& Sons, Ltd. 
17 Mental Health/ or emotional wellbeing.mp.

18 psychological wellbeing.mp.

19 emotional well-being.mp.

20 psychological well-being.mp.

21 life change event.mp. or Life Change Events/

22 affective symptom*.mp. or Affective Symptoms/

23 mental health.mp.

24 depression/ or depression.mp.

25 depressive disorder/ or dysthymic disorder/

26 anxiety.mp. or anxiety/ or anxiety disorders/

27 psychological stress.mp. or stress, psychological/

28 psychiatric status rating scales/ or psychometrics/

29 patient satisfaction.mp. or patient satisfaction/

30 benefit finding.mp.

3115 or 16 or 17 or 18 or 19 or 20 or 21 or 22 or 23 or 24 or 25 or 26 or 27 or 28 or 29 or 30

32 exp Neoplasms/

33 (cancer* or neoplasm* or carcinoma* or lymphoma*).mp.

3432 or 33

3514 and 31 and 34

36 randomized controlled trial.pt.

37 controlled clinical trial.pt.

38 randomized.ab.

39 placebo.ab.

40 clinical trials as topic.sh.

41 randomly.ab.

42 trial.ti.

4336 or 37 or 38 or 39 or 40 or 41 or 42

4435 and 43

key:

[mp=title, original title, abstract, name of substance word, subject heading word, unique identifier]

\section{Appendix 2. EMBASE search strategy}

Embase on Ovid

1 exp neoplasm/

2 (cancer* or neoplasm* or carcinoma* or lymphoma*).mp.

31 or 2

4 social support/

5 support group/

6 behavior therapy/

7 cognitive therapy/

8 family therapy/

9 psychotherapy/

10 psychoanalysis/

11 counseling/

12 mental health service/

13 (psychosocial adj (intervention* or support system)).mp.

14 self help group*.mp.

15 (therap* adj5 (educational or psychoeducational or behavior or behaviour or cognitive or cognition or family or psychoanalytic)).mp. 16 CBT.mp.

17 mental health services.mp.

Psychosocial interventions to improve quality of life and emotional wellbeing for recently diagnosed cancer patients (Review)

Copyright @ 2012 The Cochrane Collaboration. Published by John Wiley \& Sons, Ltd. 
184 or 5 or 6 or 7 or 8 or 9 or 10 or 11 or 12 or 13 or 14 or 15 or 16 or 17

19 "quality of life"/

20 mental health/

21 life event/

22 emotional disorder/

23 depression/

24 dysthymia/

25 anxiety/

26 anxiety disorder/

27 mental stress/

28 psychological rating scale/

29 psychometry/

30 patient satisfaction/

31 ((psychological or emotional) adj (wellbeing or well-being)).mp.

32 life change event.mp.

33 affective symptom*.mp.

34 mental health.mp.

35 anxiety.mp.

36 psychological stress.mp.

37 patient satisfaction.mp.

38 benefit finding.mp.

3919 or 20 or 21 or 22 or 23 or 24 or 25 or 26 or 27 or 28 or 29 or 30 or 31 or 32 or 33 or 34 or 35 or 36 or 37 or 38 403 and 18 and 39

41 random*.mp.

42 factorial*.mp.

43 (crossover* or cross over* or cross-over*).mp.

44 placebo*.mp.

45 (doubl* adj blind*).mp.

46 (singl* $^{*}$ adj blind*).mp.

47 assign*.mp.

48 allocat*.mp.

49 volunteer*.mp.

50 crossover procedure/

51 double blind procedure/

52 randomized controlled trial/

53 single blind procedure/

5441 or 42 or 43 or 44 or 45 or 46 or 47 or 48 or 49 or 50 or 51 or 52 or 53

5540 and 54

\section{Appendix 3. CENTRAL search strategy}

\#1 MeSH descriptor Neoplasms explode all trees

\#2 cancer* or neoplasm* or carcinoma* or lymphoma*

\#3 (\#1 OR \#2)

\#4 MeSH descriptor Social Support, this term only

\#5 MeSH descriptor Self-Help Groups, this term only

\#6 MeSH descriptor Behavior Therapy, this term only

\#7 MeSH descriptor Cognitive Therapy, this term only

\#8 MeSH descriptor Family Therapy, this term only

\#9 MeSH descriptor Psychotherapy, this term only

\#10 MeSH descriptor Psychoanalytic Therapy, this term only

\#11 MeSH descriptor Counseling, this term only

Psychosocial interventions to improve quality of life and emotional wellbeing for recently diagnosed cancer patients (Review)

Copyright $\odot 2012$ The Cochrane Collaboration. Published by John Wiley \& Sons, Ltd. 
\#12 MeSH descriptor Mental Health Services, this term only

\#13 psychosocial next (intervention* or (support system))

\#14 self help group*

\#15 therap* near/5 (educational or psychoeducational or behavior or behaviour or cognitive or cognition or family or psychoanalytic)

\#16 CBT

\#17 mental health services

\#18 (\#4 OR \#5 OR \#6 OR \#7 OR \#8 OR \#9 OR \#10 OR \#11 OR \#12 OR \#13 OR \#14 OR \#15 OR \#16 OR \#17)

\#19 MeSH descriptor Quality of Life, this term only

\#20 MeSH descriptor Mental Health, this term only

\#21 MeSH descriptor Life Change Events, this term only

\#22 MeSH descriptor Affective Symptoms, this term only

\#23 MeSH descriptor Depression, this term only

\#24 MeSH descriptor Depressive Disorder, this term only

\#25 MeSH descriptor Dysthymic Disorder, this term only

\#26 MeSH descriptor Anxiety, this term only

\#27 MeSH descriptor Anxiety Disorders, this term only

\#28 MeSH descriptor Stress, Psychological, this term only

\#29 MeSH descriptor Psychiatric Status Rating Scales, this term only

\#30 MeSH descriptor Psychometrics, this term only

\#31 MeSH descriptor Patient Satisfaction, this term only

\#32 (psychological or emotional) next (wellbeing or well-being)

\#33 (life change event)

\#34 affective symptom*

\#35 mental health

\#36 anxiety

\#37 psychological stress

\#38 patient satisfaction

\#39 benefit finding

\#40 (\#19 OR \#20 OR \#21 OR \#22 OR \#23 OR \#24 OR \#25 OR \#26 OR \#27 OR \#28 OR \#29 OR \#30 OR \#31 OR \#32 OR \# 33 OR \#34 OR \#35 OR \#36 OR \#37 OR \#38 OR \#39)

\#41 (\#3 AND \#18 AND \#40)

\section{Appendix 4. PsycINFO}

PsychInfo on Ovid

1 exp neoplasms/

2 (cancer* or neoplasm* or carcinoma* or lymphoma*).mp.

31 or 2

4 social support/

5 Support Groups/

6 behavior therapy/

7 Cognitive Therapy/

8 Family Therapy/

9 Psychotherapy/

10 Psychoanalysis/

11 Counseling/

12 Mental Health Services/

13 (psychosocial adj (intervention* or support system)).mp.

14 self help group*.mp.

15 (therap* adj5 (educational or psychoeducational or behavior or behaviour or cognitive or cognition or family or psychoanalytic)).mp. 16 CBT.mp.

Psychosocial interventions to improve quality of life and emotional wellbeing for recently diagnosed cancer patients (Review)

Copyright @ 2012 The Cochrane Collaboration. Published by John Wiley \& Sons, Ltd. 
17 mental health services.mp.

184 or 5 or 6 or 7 or 8 or 9 or 10 or 11 or 12 or 13 or 14 or 15 or 16 or 17

19 "Quality of Life"/

20 Mental Health/

21 Life Changes/

22 Affective Disorders/

23 "Depression (Emotion)"/

24 Dysthymic Disorder/

25 Anxiety/

26 Anxiety Disorders/

27 exp Psychological Stress/

28 Rating Scales/

29 Psychometrics/

30 Client Satisfaction/

31 ((psychological or emotional) adj (wellbeing or well-being)).mp.

32 life change event.mp.

33 affective symptom*.mp.

34 mental health.mp.

35 anxiety.mp.

36 psychological stress.mp.

37 patient satisfaction.mp.

38 benefit finding.mp.

3919 or 20 or 21 or 22 or 23 or 24 or 25 or 26 or 27 or 28 or 29 or 30 or 31 or 32 or 33 or 34 or 35 or 36 or 37 or 38

403 and 18 and 39

key:

[mp=title, abstract, heading word, table of contents, key concepts]

\section{H IS T O R Y}

Protocol first published: Issue 2, 2008

Review first published: Issue 11, 2012

\section{CONTRIBUTIONSOFAUTHORS}

Contribution to protocol: KG; conception of review, development of search strategies and drafting of protocol. CC; statistical advice on meta-analysis. $\mathrm{AB}, \mathrm{MC}$ and $\mathrm{MM}$; conception and initial development of review. MD; editorial supervision.

Contribution to review: $\mathrm{KG}, \mathrm{AB}, \mathrm{MC}, \mathrm{CC}, \mathrm{MM}$ and $\mathrm{MD}$; selection and data extraction process (including decisions on scope), development and editing of main text. KG; meta-analysis, narrative analysis, drafting text of review. MD; editorial supervision.

Psychosocial interventions to improve quality of life and emotional wellbeing for recently diagnosed cancer patients (Review) 


\section{DECLARATIONSOF INTEREST}

None

\section{SOURCES OF SUPPORT}

\section{Internal sources}

- No sources of support supplied

\section{External sources}

- Research and Development Office, Northern Ireland, UK.

\section{DIFFERENCESBETWEEN PROTOCOLANDREVIEW}

The scope of the review was reduced to include only interventions carried out with individuals. All group, family and couple-based therapeutic interventions have been excluded from the review. This decision was made on the basis of the volume and variety of intervention formats appearing in the search results that could be usefully compared. Subgroup comparisons (3) examined mode of intervention delivery, that is face-to-face or telephone. It was not be possible to carry out proposed subgroup analyses (4) emotional state at the time of the intervention as the majority of studies excluded participants with a history of psychiatric morbidity, and did not report separate data for participants who displayed suspected psychological distress at baseline. Subgroup analysis (5) was not carried out between or within studies because authors generally report stage and mode of clinical treatment programme at a group level, rarely carrying out sensitivity analyses to examine individual differences related to stage or mode of treatment within trials. 